\title{
De Limburgse arbeidsmarkt 2001-2006
}

Citation for published version (APA):

Diephuis, B. J., de Grip, A., \& Golsteyn, B. H. H. (2002). De Limburgse arbeidsmarkt 2001-2006.

Researchcentrum voor Onderwijs en Arbeidsmarkt, Faculteit der Economische Wetenschappen. ROA Reports No. 1 https://doi.org/10.26481/umarep.2002001

Document status and date:

Published: 01/01/2002

DOI:

10.26481/umarep.2002001

Document Version:

Publisher's PDF, also known as Version of record

\section{Please check the document version of this publication:}

- A submitted manuscript is the version of the article upon submission and before peer-review. There can be important differences between the submitted version and the official published version of record.

People interested in the research are advised to contact the author for the final version of the publication, or visit the DOI to the publisher's website.

- The final author version and the galley proof are versions of the publication after peer review.

- The final published version features the final layout of the paper including the volume, issue and page numbers.

Link to publication

\footnotetext{
General rights rights.

- You may freely distribute the URL identifying the publication in the public portal. please follow below link for the End User Agreement:

www.umlib.nl/taverne-license

Take down policy

If you believe that this document breaches copyright please contact us at:

repository@maastrichtuniversity.nl

providing details and we will investigate your claim.
}

Copyright and moral rights for the publications made accessible in the public portal are retained by the authors and/or other copyright owners and it is a condition of accessing publications that users recognise and abide by the legal requirements associated with these

- Users may download and print one copy of any publication from the public portal for the purpose of private study or research.

- You may not further distribute the material or use it for any profit-making activity or commercial gain

If the publication is distributed under the terms of Article $25 \mathrm{fa}$ of the Dutch Copyright Act, indicated by the "Taverne" license above, 


\section{De Limburgse arbeidsmarkt 2001-2006}

ROA-R-2002/1

B.J. Diephuis

B. Golsteyn

A. de Grip

Researchcentrum voor Onderwijs en Arbeidsmarkt

Faculteit der Economische Wetenschappen en Bedrijfskunde

Universiteit Maastricht

Maastricht, maart 2002 
DE UMBURGSE ARBEIDSMARKT 2001-2006

Niets uit deze uitgave mag worden verveelvoudigd en/of openbaar gemaakt door middel van druk, fotokopie, microfilm, of op welke wijze ook, zonder voorafgaande schriftelijke toestemming van de directeur van het Researchcentrum voor Onderwijs en Arbeidsmarkt. In geval van overname van het datamateriaal moet telkens als bron worden vermeld: "Researchcentrum voor Onderwijs en Arbeidsmarkt" of "ROA". Van publicaties waarin gebruik wordt gemaakt van gegevens uit dit rapport ontvangen wij gaarne een exemplaar.

Hoewel de grootst mogelijke zorg is besteed aan de inhoud van dit rapport, kan het ROA in generlei opzicht verantwoordelijkheid op zich nemen voor eventuele onvolledigheden of onjuistheden.

\section{Colofon}

Vormgeving omslag Lay-out, dtp en druk Oplage

ISBN 90-5321-327-9
Lenting en Terlingen Grafisch Ontwerp Unigraphic, Universiteit Maastricht 900 exemplaren 


\section{Inhoudsopgave}

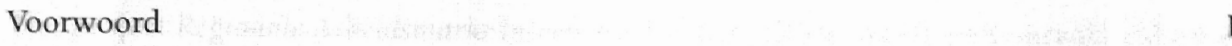

Verschenen RAIL-publicaties

Ten geleide $\quad V$

1 De Limburgse arbeidsmarkt in vogelvlucht 1

1.1 Inleiding 2

1.2 De arbeidsmarkt in Limburg: 1997-2001 2

1.3 De verwachte arbeidsmarktontwikkelingen in Limburg 10

1.4 Knelpunten op de Limburgse arbeidsmarkt: Mogelijke oplossingen 16

2 De arbeidsmarktpositie van $\mathrm{MBO}$-schoolverlaters in Limburg 21

$\begin{array}{lll}2.1 & \text { Inleiding } & 21\end{array}$

2.2 Leerlingenaantallen en gediplomeerden van het MBO in Limburg 22

2.3 Arbeidsmarktpositie van MBO-schoolverlaters 24

$\begin{array}{ll}2.3 .1 & \text { Open discrepanties } \\ 2.3 .2 & 24\end{array}$

$\begin{array}{ll}2.3 .2 & \text { Verborgen discrepanties }\end{array}$

3 De Limburgse arbeidsmarkt op de korte en de middellange termijn 33

3.1 Inleiding 33

3.2 Uitbreidingsvraag 34

3.3 Vervangingsvraag 40

3.4 Totale vraag naar schoolverlaters 45

3.5 Aanbod van schoolverlaters $\quad 50$

$4 \quad$ Knelpunten en perspectieven op de Limburgse arbeidsmarkt 55

4.1 Inleiding 56

4.2 Perspectieven en knelpunten in de personeelsvoorziening in Limburg 56

4.3 Aandachtspunten voor een vraaggericht scholingsbeleid in Limburg 63

5 De werklozen en niet-participerenden in Limburg 71

$\begin{array}{ll}5.1 & \text { Inleiding }\end{array}$

5.2 Omvang en samenstelling van de werklozen en de niet-participerenden 72

5.3 Arbeidsverleden van de werklozen en de niet-participerenden 75

5.4 Tijdsbesteding en tevredenheid van de werklozen en $\begin{array}{ll}\text { de niet-participerenden } & 77\end{array}$

5.5 Inzetbaarheid van de werklozen en de niet-participerenden $\quad 79$

Verklarende woordenlijst 
DE LIMEURGSE ARBEIDSMARKT 2001-2006 


\section{Voorwoord}

Het project Regionale Arbeidsmarkt Informatie Limburg (RAIL) heeft zich ontwikkeld tot een gewaardeerde en veel geciteerde bron van informatie over de ontwikkelingen op de Limburgse arbeidsmarkt. De regionale arbeidsmarkt informatie, die het project RAIL oplevert, wordt door veel partijen in de provincie Limburg van belang geacht. Voor u ligt de vijfde set van publicaties van RAIL, De Limburgse arbeidsmarkt 2001-2006. De publicaties zijn samengesteld door het Researchcentrum voor Onderwijs en Arbeidsmarkt (ROA) en het Economisch Technologisch Instituut Limburg (ETIL), beide verbonden aan de Universiteit Maastricht.

Evenals vorig jaar bestaat deze jaargang uit tien delen, waaronder de beknopte rapportage, het hoofdrapport, de statistische bijlage en zeven rayonrapportages. Qua methodiek en aanpak ligt de uitgave in de lijn van voorgaande jaren: actueel, vernieuwend en oplossingsgericht. Allereerst zijn er dit jaar nieuwe middellange termijn prognoses tot 2006 opgesteld. Verder wordt dieper ingegaan op de beschikbaarheid en tijdsbesteding van het onbenut arbeidspotentieel in Limburg. Bovendien is in de rayonrapportages veel informatie te vinden over arbeidsmarktontwikkelingen en oplossingsrichtingen op lokaal niveau. Daarbij wordt in het bijzonder de industriële sector belicht. Tot slot kan met enige trots worden gemeld dat de Euregionale aspecten van de Limburgse arbeidsmarkt inmiddels hebben geleid tot een apart project Euregionaal RAIL. Onlangs is in dit kader het eerste onderzoeksrapport uitgebracht, te weten: Naar de arbeidsmarkt zonder grenzen; 2001.

De Limburgse economie heeft zich de laatste jaren zeer voorspoedig ontwikkeld. In 2001 is het groeitempo echter wel sterk afgenomen. Hoewel de onzekerheid over de toekomstige economische ontwikkeling duidelijk is toegenomen, zal naar verwachting de economische groei in Limburg in de nabije toekomst positief blijven. Mede als gevolg van de afremmende economische groei ligt het aantal openstaande vacatures in 2001 op een wat lager niveau dan in de jaren daarvoor. Desalniettemin is het aantal openstaande vacatures nog veel groter dan vier jaar geleden in de eerste RAIL-rapportage werd gemeten, en is er nog steeds sprake van een krappe arbeidsmarkt.

De krapte op de arbeidsmarkt kan een oorzaak zijn geweest van de afgenomen economische groei. Door het gebrek aan gekwalificeerd personeel blijven immers veel vacatures onvervuld, waardoor bedrijven hun groeimogelijkheden niet kunnen realiseren. De krapte op de arbeidsmarkt heeft mede geleid tot een sterkere loonkostenontwikkeling. Hierdoor wordt verwacht dat op middellange termijn de groei van de Limburgse werkgelegenheid afvlakt tot circa $0,8 \%$ gemiddeld per jaar. Toch zullen de knelpunten op de Limburgse arbeidsmarkt ook de komende jaren groot blijven. Vanwege de vergrijzing van de werkzame bevolking is de vervangingsvraag in Limburg namelijk hoog, en naar verhouding zelfs groter dan in de rest van Nederland. Ook op de middellange termijn is de instroom van nieuwkomers op de arbeidsmarkt niet toereikend om in de vraag te kunnen voorzien. De inzet van onbenut arbeidspotentieel en buitenlandse arbeidskrachten blijft geboden.

Toch is er een belangrijke nuance te plaatsen bij deze algemene trend. De vooruitzichten voor on- en laaggeschoolden zijn niet rooskleurig. Voor schoolverlaters van het VMBO land- 
bouw en natuurlijke omgeving en VMBO economie zijn de perspectieven (op middellange termijn) bijvoorbeeld ronduit slecht. Soms kunnen 'drop-outs' uit het initiële onderwijs direct na het verlaten van hun school nog wel gemakkelijk aan de slag. Echter, bij verlies van hun baan vormen deze mensen geen concurrentie voor nieuwe, ongeschoolde schoolverlaters die tegen een veel lager loon kunnen worden aangetrokken en vaak ook productiever zijn. Ongeschoolde arbeidskrachten die niet door het volgen van aanvullende scholing een 'startkwalificatie' voor de arbeidsmarkt op het MBO-niveau van 'basisberoepsbeoefenaar' weten te behalen, komen derhalve in een soort fuik terecht. Hierdoor lopen deze ongeschoolden op relatief jonge leeftijd het risico langdurig werkloos te worden of de arbeidsmarkt geheel te verlaten.

In het RAIL-rapport wordt erop gewezen dat het arbeidsmarktbeleid in Limburg succesvol is geweest. Het aantal openstaande vacatures is mede gedaald vanwege een verbeterde aansluiting tussen vraag en aanbod. Het aantal langdurig werkzoekenden is met maar liefst $20 \%$ gedaald. Zowel het aantal minder goed bemiddelbare werkzoekenden als het aantal slecht bemiddelbare werkzoekenden is met enkele duizenden mensen gedaald.

Toch zijn er in Limburg in het jaar 2001 nog ruim dertig duizend werklozen en vijftien duizend openstaande vacatures. Er zullen nog veel inspanningen moeten worden verricht om beide aantallen verder terug te brengen. RAIL heeft een taak om inzicht te geven in het (specifieke) cijfermateriaal en in mogelijke oplossingsrichtingen. Het is echter aan werkgevers, werkzoekenden en diverse beleidsforums om een en ander daadwerkelijk te realiseren.

Een belangrijk beleidsplatform voor het arbeidsmarkt- en onderwijsbeleid in Limburg is het Vertrouwenpact Werkgelegenheid Limburg. Hierin zijn de Provincie, de sociale partners, het onderwijsveld, de gemeenten, en het Centrum voor Werk en Inkomen vertegenwoordigd. Op rayonaal niveau zijn bovendien de Regionale Platforms Arbeidsmarktbeleid ontstaan. Het is aan hén om de uitkomsten van het RAIL-onderzoek te vertalen in adequaat arbeidsmarktbeleid en gerichte acties.

Het project Regionale Arbeidsmarkt Informatie Limburg (RAIL) maakt de arbeidsmarkt transparanter en het arbeidsmarktbeleid consistenter. Daarom ben ik ervan overtuigd dat RAIL ook de komende jaren een solide basis zal vormen voor het vinden van de juiste oplossingen voor knelpunten op de Limburgse arbeidsmarkt.

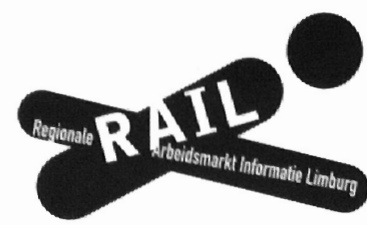




\section{Verschenen RAIL-publicaties:}

98.RAIL-01: De Limburgse arbeidsmarkt 1997-2002; hoofdrapport *

98.RAIL-02: De Limburgse arbeidsmarkt 1997-2002; statistische bijlage*

98.RAIL-03: Kwalitatieve informatie over de Limburgse arbeidsmarkt; werkdocumenten industrie, handel*

99.RAIL-04: De Limburgse arbeidsmarkt 1998-2002; hoofdrapport

99.RAIL-05: De Limburgse arbeidsmarkt 1998-2002; statistische bijlage

99.RAIL-06: De Limburgse arbeidsmarkt 1998-2002; sectorrapportage bouw, zakelijke dienstverlening, zorg

99.RAIL-07: De Limburgse arbeidsmarkt 1998-2002; beknopte rapportage

00.RAIL-08: De Limburgse arbeidsmarkt 1999-2004; hoofdrapport

00.RAIL-09: De Limburgse arbeidsmarkt 1999-2004; statistische bijlage

00.RAIL-10: De Limburgse arbeidsmarkt 1999-2004; sectorrapportage horeca, toerisme $\&$ recreatie, en overheid

00.RAIL-11: De Limburgse arbeidsmarkt 1999-2004; beknopte rapportage

01.RAIL-12: De Limburgse arbeidsmarkt 2000-2004; hoofdrapport

01.RAIL-13: De Limburgse arbeidsmarkt 2000-2004; statistische bijlage

01.RAIL-14: De Limburgse arbeidsmarkt 2000-2004; rayonrapportage Maastricht Mergelland

01.RAIL-15: De Limburgse arbeidsmarkt 2000-2004; rayonrapportage Parkstad Limburg

01.RAIL-16: De Limburgse arbeidsmarkt 2000-2004; rayonrapportage Westelijke Mijnstreek

01.RAIL-17: De Limburgse arbeidsmarkt 2000-2004; rayonrapportage Roermond

01.RAIL-18: De Limburgse arbeidsmarkt 2000-2004; rayonrapportage Weert

01.RAIL-19: De Limburgse arbeidsmarkt 2000-2004; rayonrapportage Venlo

01.RAIL-20: De Limburgse arbeidsmarkt 2000-2004; rayonrapportage Venray

01.RAIL-21: De Limburgse arbeidsmarkt 2000-2004; beknopte rapportage

02.RAIL-22: Naar de arbeidsmarkt zonder grenzen; 2001; eerste ontwikkeljaar

02.RAIL-23: De Limburgse arbeidsmarkt 2001-2006; hoofdrapport

02.RAIL-24: De Limburgse arbeidsmarkt 2001-2006; statistische bijlage

02.RAIL-25: De Limburgse arbeidsmarkt 2001-2006; rayonrapportage Maastrichı Mergelland

02.RAIL-26: De Limburgse arbeidsmarkt 2001-2006; rayonrapportage Parkstad Limburg

02.RAIL-27: De Limburgse arbeidsmarkt 2001-2006; rayonrapportage Westelijke Mijnstreek

02.RAIL-28: De Limburgse arbeidsmarkt 2001-2006; rayonrapportage Roermond

02.RAIL-29: De Limburgse arbeidsmarkt 2001-2006; rayonrapportage Weert

02.RAIL-30: De Limburgse arbeidsmarkt 2001-2006; rayonrapportage Venlo

02.RAIL-31: De Limburgse arbeidsmarkt 2001-2006; rayonrapportage Venray

02.RAIL-32: De Limburgse arbeidsmarkt 2001-2006; beknopte rapportage

* Publicatie niet meer in boekvorm verkrijgbaar.

\section{RAIL op internet:}

www.railsite.nl 
DE LMMUURGS ARBEIDSMARKT 2001-2006 


\section{Ten geleide}

Van verschillende zijden bestaat er behoefte aan betrouwbare informatie over de actuele en toekomstige arbeidsmarktsituatie in de provincie Limburg. Deze informatiebehoefte vormde de aanleiding tot het project Regionale Arbeidsmarkt Informatie Limburg (RAIL), dat beoogt te komen tot een geintegreerd informatiesysteem toegespitst op de provincie Limburg. In het RAIL-project participeren: CWI Zuidoost-Nederland (voorheen Arbeidsvoorziening), de Provincie Limburg, de zeven kerngemeenten (Heerlen, Maastricht, Roermond, Sittard-Geleen, Venlo, Venray en Weert), de vier Regionale Opleidingscentra in Limburg (Arcus College, Gilde Opleidingen, Leeuwenborgh Opleidingen en het AOC Limburg), de Federatie Nederlandse Vakbeweging (FNV), en de Limburgse Werkgevers Vereniging (LWV). Er wordt derhalve binnen RAIL samengewerkt door een aantal partners die zowel gebruiker als leverancier van informatie zijn. RAIL is hiermee één van de kernactiviteiten van het Vertrouwenspact Limburg, een breed bestuurlijk platform waarin partijen beleidsafspraken maken met betrekking tot arbeidsmarkt en beroepsopleidingen.

Het thans voor $\mathrm{u}$ liggende rapport De Limburgse arbeidsmarkt 2001-2006 vormt de vijfde uitgave van het hoofdrapport van het RAIL project. Het rapport is samengesteld door het Researchcentrum voor Onderwijs en Arbeidsmarkt (ROA). Het rapport is primair gericht op het in kaart brengen van de actuele en toekomstige discrepanties naar bedrijfssector, beroep en opleiding op de Limburgse arbeidsmarkt. Door zowel de huidige situatie als de toekomstige ontwikkelingen te beschrijven, heeft RAIL hiermee een signaleringsfunctie voor diverse gebruiksdoelen. Hierbij kan gedacht worden aan het personeels- en rekruteringsbeleid van werkgevers, het initiëren en bijsturen van bij- en omscholingsprogramma's voor niet-werkende werkzoekenden, de arbeidsbemiddeling en het arbeidsmarkt- en onderwijsbeleid. Tegelijkertijd met dit rapport verschijnt ook de bijbehorende Statistische Bijlage. Hierin wordt een systematisch kwantitatief overzicht gegeven van de actuele arbeidsmarkıgegevens en de verwachte ontwikkelingen die ten grondslag liggen aan dit hoofdrapport.

Het rapport bestaat uit vijf hoofdstukken. De eerste drie hoofdstukken geven een overzicht van de huidige en toekomstige ontwikkelingen op de Limburgse arbeidsmarkt. In hoofdstuk 1 wordt een globaal overzicht gegeven van de belangrijkste arbeidsmarktontwikkelingen verbijzonderd naar bedrijfs-, beroeps- en opleidingssector. In hoofdstuk 2 wordt cen overzicht gepresenteerd van de actuele leerlingenaantallen in het MBO in Limburg op basis van data van de Limburgse ROC's. Tevens wordt in het hoofdstuk aangegeven wat de mate van open en verborgen discrepanties op de arbeidsmarkt is voor schoolverlaters van het $\mathrm{MBO}$. Deze bespreking van de arbeidsmarktpositie van $\mathrm{MBO}$-schoolverlaters gebeurt als altijd op basis van het Schoolverlaters Informatie Systeem (SIS) van het ROA. Hoofdstuk 3 gaat nader in op de te verwachten ontwikkelingen an zowel de vraag-als aanbodzijde van de Limburgse arbeidsmarkt op de korte termijn en op de middellange termijn. Het confronteren van vraag en aanbod resulteert vervolgens in hoofdstuk 4 in een overzicht van de te verwachten discrepanties naar opleiding en beroep in 2002 en voor de periode 2001-2006. Verder wordt er in dit hoofdstuk aandacht besteed aan de vraag in hoeverre het mogelijk is om via scholing van niet-werkende werkzoekenden de discrepanties op de Limburgse arbeidsmarkt te verminderen. In hoofdstuk 5 wordt nader ingegaan op het niet-participe- 
DE LMMUURGSE ARBEIDSMARKT 2001-2006

rende arbeidsaanbod in Limburg. Dit betreft dan in het bijzonder het onderzoeken van de mogelijkheden om door het stimuleren van het arbeidsaanbod de bestaande en verwachte knelpunten in de personeelsvoorziening in Limburg te verminderen.

In aansluiting op het hoofdrapport en de bijbehorende Statistische Bijlage verschijnen dit jaar voor de tweede keer zeven rayonrapportages. Hierin wordt de arbeidsmarktsituatie per rayon in beeld gebracht. De rayonrapportages worden verzorgd door ETIL. Het voorliggende rapport (incl. Statistische Bijlage) en de rayonrapportages van ETIL zijn in onderlinge samenwerking tot stand gekomen, zodanig dat er consistentie bestaat in gehanteerde definities en aantallen.

De projectleiding van RAIL is bij het ROA in handen geweest van A. de Grip. Aan de huidige versie van het hoofdrapport en de bijbehorende Statistische Bijlage is bij het ROA meegewerkt door F. Cörvers, B.J. Diephuis, B. Golsteyn, R. Leclercq en G. Nekkers.

Onze dank gaat uit naar de leden van de RAIL-stuurgroep en het RAIL-projectteam. De volgende personen hebben hierin zitting: $G$. Ahn (CWI Zuidoost-Nederland), M. te Baerts (Leeuwenborgh Opleidingen), L. Burdorf (Gemeente Sittard-Geleen), A. Christophe (AOC Limburg), H. Duijvestein (CWI Zuidoost-Nederland, projectleider), P. Göbbels (FNV Regiowerk ZON), L. Hodzelmans (AOC Limburg), W. Houben (Gemeente Heerlen), W. Huurdeman (Gilde Opleidingen), H. Janssen (Gemeente Venlo), W. Kohl (Arcus College), N. Naus (Intergemeentelijk Steunpunt), P. Peters (Arcus College), K. Scholtissen (Gemeente Heerlen), L. Simons-Heldens (Gilde Opleidingen), M. van Smoorenburg (CWI Zuidoost-Nederland), J. Soogelée (Leeuwenborgh Opleidingen), J. Sørensen (DSM Limburg; voorzitter), A. Timmermans (CWI Zuidoost-Nederland), R. Widdershoven (Provincie Limburg), G. Wolfs (Provincie Limburg) en L. Zeegers (MIT). 


\section{De Limburgse arbeidsmarkt in vogelvlucht}

De Limburgse economie heeft zich de laatste jaren zeer voorspoedig ontwikkeld. In 2001 is het groeitempo echter wel sterk afgenomen. Hoewel de onzekerheid over de toekomstige economische ontwikkeling duidelijk is toegenomen, zal naar verwachting de economische groei in Limburg ook in de nabije toekomst positief blijven. Mede als gevolg van de afremmende economische groei ligt het aantal openstaande vacatures in 2001 op een wat lager niveau dan in de jaren daarvoor. Desalniettemin is het aantal openstaande vacatures nog veel groter dan vier jaar geleden in de eerste RAIL-rapportage werd gemeten. Opmerkelijk is ook dat het percentage langdurig openstaande vacatures in 2001 sterk is gestegen. Dit geeft aan dat het de laatste jaren veel moeilijker is geworden geschikt personeel te vinden.

Het is belangrijk om te constateren dat het aantal niet-werkende werkzoekenden tussen april 2000 en april 2001 sterk is afgenomen. Dit betekent ook dat het aantal openstaande vacatures mede is gedaald vanwege een verbeterde aansluiting tussen vraag en aanbod. Opmerkelijk is in dit verband dat het aantal langdurig werkzoekenden met maar liefst $20 \%$ is gedaald. Dit wijst er op dat het arbeidsmarktbeleid in Limburg succesvol is geweest. Zowel het aantal minder goed bemiddelbare werkzoekenden (ingedeeld in fase 2 en 3) als het aantal thans onbemiddelbare werkzoekenden (ingedeeld in fase 4) is met enkele duizenden mensen gedaald. Opmerkelijk is in dit verband ook dat de frictiewerkloosheid die de afgelopen jaren op een ondergrens van 1,5\% leek te liggen nog verder gedaald is tot $1,2 \%$ van de werkzame bevolking.

De arbeidsmarktkrapte blijkt in 2001 ondanks de daling van het aantal vacatures groter te zijn geworden. In april 2001 stonden tegenover iedere 100 direct bemiddelbare werkzoekenden maar liefst 251 openstaande vacatures.

Ook de komende jaren zal de arbeidsmarkt in Limburg ondanks de afnemende economische groei naar verwachting gunstig blijven. Voor de komende jaren wordt een economische groei van gemiddeld 1,7\% verwacht, ongeveer de helft van de groei in de hoogconjunctuur aan het eind van de jaren negentig. De economische groei vertaalt zich in 2002 in een groei van de werkgelegenheid ter grootte van 1,1\%. In totaal zullen er voor Limburgse schoolverlaters in 2002 circa 26.000 banen beschikbaar zijn. Tegenover een instroom van minder dan 23.000, leide dit tot een vraagoverschot in 2002 van ongeveer 3.000. Op de middellange termijn wordt verwacht dat de groei van de werkgelegenheid nog wat verder afvlakt tot circa 0,8\% gemiddeld per jaar. Dit laatste betekent dat de vervangingsvraag voor een nog groter deel van de baanopeningen voor nieuwkomers op de arbeidsmarkt verantwoordelijk zal zijn. Vanwege de vergrijzing van de werkzame bevolking is deze vervangingsvraag in Limburg naar verhouding nog groter dan in de rest van Nederland. Ook op de middellange termijn is de instroom van nieuwkomers op de arbeidsmarkt niet toereikend om in de vraag te kunnen voorzien. Hierdoor zullen de knelpunten op de Limburgse arbeidsmarkt ook de komende jaren nog groot blijven.

Het spreekt voor zich dat er tussen de verschillende segmenten op de arbeidsmarkt soms grote verschillen zijn in de ontwikkelingen van vraag en aanbod en de daaruit resulterende knelpunten op de arbeidsmarkt. Zo zal naar verwachting in een aantal bedrijfssectoren de komende jaren de werkgelegenheid krimpen. Deze krimp zal zich met name voordoen in de sector Landbouw en visserij en in de sector Overige industrie. Opmerkelijk is ook dat er op middellange termijn een 
trendbreuk in de werkgelegenheidsontwikkeling in het Bank- en verzekeringswezen wordt verwacht. Na een jarenlange sterke groei van de werkgelegenheid zal er voor deze sector na 2002 sprake zijn van een daling van de werkgelegenheid. De overige dienstensectoren groeien daarentegen veel sterker dan gemiddeld.

De verwachte knelpunten in de personeelsvoorziening zijn voor de meeste beroepssectoren in 2002 groot. Op de middellange termijn zullen naar verwachting vooral in de Openbare orde- en veiligheidsberoepen, de Technische en industrieberoepen en de Agrarische beroepen de knelpunten op de arbeidsmarkt afnemen. Verwacht wordt echter dat dit niet ten koste gaat van de arbeidsmarktperspectieven van de schoolverlaters in deze beroepsgroepen. De knelpunten in de personeelsvoorziening zullen zich de komende jaren vooral voordoen bij de middelbaar en hoger opgeleiden. Aan de onderkant van de arbeidsmarkt zullen de knelpunten op de arbeidsmarkt de komende jaren veel kleiner worden en bij verschillende opleidingssectoren geheel verdwijnen. Voor de schoolverlaters betekent dit dat de arbeidsmarktperspectieven voor de middelbaar en hoger opgeleiden over de hele linie gunstig zullen blijven. Daarentegen zullen de arbeidsmarktperspectieven voor schoolverlaters zonder een zogenaamde 'startkwalificatie? op het (MBO)niveau van basisberoepsbeoefenaar' minder gunstig worden, al zullen voortijdig schoolverlaters bij hun start op de arbeidsmarkt waarschijnlijk nog wel aan het werk kunnen komen. De problemen zullen zich met name voordoen als ze op iets oudere leeftijd hun werk verliezen en niet meer kunnen concurreren met de goedkopere en vaak ook meer productieve schoolverlaters.

\subsection{Inleiding}

In dit hoofdstuk zal een overzicht worden gegeven van de recente en verwachte toekomstige ontwikkelingen op de Limburgse arbeidsmarkt. Verschillende aspecten komen daarbij aan de orde. In paragraaf 1.2 zal worden ingegaan op de economische ontwikkeling en de veranderingen in de werkgelegenheidsstructuur in Limburg tussen 1997 en 2001. In aansluiting daarop zal de ontwikkeling van het aantal openstaande vacatures en nietwerkende werkzoekenden en de daaruit resulterende arbeidsmarktkrapte in kaart worden gebracht. Aansluitend zal in paragraaf 1.3 worden ingegaan op de verwachte arbeidsmarktontwikkelingen op de korte en middellange termijn, verbijzonderd naar bedrijfs-, beroepsen opleidingssector. Ter afsluiting wordt in paragraaf 1.4 kort ingegaan op een aantal mogelijkheden om de toekomstige arbeidsmarktknelpunten in Limburg te verminderen.

\subsection{De arbeidsmarkt in Limburg: 1997-2001}

\section{Economische groei en werkgelegenheid}

De Limburgse economie heeft zich de laatste jaren zeer voorspoedig ontwikkeld. In 2001 is het groeitempo echter wel sterk afgenomen. De economische groei in 2001 is nog 1,5\%. Dit is minder dan de helft van de groei in de hoogconjunctuur aan het eind van de jaren negentig. De economische groei in Limburg ligt daarmee evenals in de afgelopen jaren op een iets lager niveau dan de landelijke groeicijfers. Eén en ander wordt weergegeven in tabel 1.1. 
Tabel 1.1

Ontwikkeling van de economische groei (jaarlijkse groei van het BNP, in procenten), Nederland en Limburg, 1997-2001

\begin{tabular}{lrrrrr} 
& $\begin{array}{rrrrr}1997 \\
\%\end{array}$ & $\begin{array}{r}1998 \\
\%\end{array}$ & $\begin{array}{r}1999 \\
\%\end{array}$ & $\begin{array}{r}2000 \\
\%\end{array}$ & $\begin{array}{r}2001 \\
\%\end{array}$ \\
\cline { 1 - 6 } Nederland & 3,8 & 4,3 & 3,7 & 3,5 & 2,0 \\
Limburg & 4,4 & 3,9 & 3,5 & 3,1 & 1,5 \\
\hline
\end{tabular}

Bron: ETIL

Economische groei vertaalt zich over het algemeen in een groei van de werkgelegenheid, al wordt een deel van de groei ook gerealiseerd door het stijgen van de arbeidsproductiviteit vanwege investeringen in nieuwe productiemiddelen of efficiency verbeteringen in de organisatie van het productieproces. Daarbij kan het overigens zo zijn dat vanwege de knelpunten op de arbeidsmarkt werkgevers er eerder toe overgaan in nieuwe kapitaalgoederen te investeren. Daardoor kunnen ze de gewenste productiestijging realiseren zonder meer mensen aan te trekken.

Overigens kan de krapte op de arbeidsmarkt een oorzaak zijn geweest van de afgenomen economische groei. Door de krapte op de Limburgse arbeidsmarkt blijven immers veel vacatures onvervuld, waardoor bedrijven hun groeimogelijkheden niet kunnen realiseren. De krapte op de arbeidsmarkt heeft ook geleid tot een sterkere loonkostenontwikkeling. Een toenemend aantal bedrijven probeert door het verhogen van de lonen de knelpunten in de personeelsvoorziening te verminderen. Hierdoor verslechtert de concurrentiepositie van het bedrijfsleven met name tot het eurogebied, en Duitsland in het bijzonder'. Ook dit heeft waarschijnlijk een remmende werking gehad op de economische groei in Limburg en zal de komende jaren het groeitempo van bedrijven die te maken hebben met internationale concurrentie op hun afzetmarkten afzwakken. 
DE UMEURGSE ARBEIDSMARKT 2001-2006

Tabel 1.2

Trends in de Limburgse werkgelegenheid, 1997- 2000

Kenmerk gemiddelde gemiddelde gemiddelde

$1997-1998 \quad 1998-1999 \quad 1999-2000$

Aantal werkenden:

463.500

466.500

472.500

$\%$

$\%$

Bedrijfssector:

Primaire sector

- Landbouw en visserij

Secundaire sector

3

25

24

23

- Voeding

- Chemie

- Metaal en elektrotechniek

- Overige industrie

- Energie

Tertiaire sector

- Bouw en onroerend goed

- Handel en reparatie

- Transport en communicatie

- Bank- en verzekeringswezen

- Horeca en zakelijke dienstverlening Kwartaire sector

- Kwartaire diensten

- Overheid en onderwijs

Leeftijd:

Jongeren (15-29)

Ouderen (50-64)

Geslacht:

Vrouwen

Contract:

Flexibel werk

Deeltijdwerk

Zelfstandigen
44

\section{Bron: $C B S / R O A$}

\section{9}


Tabel 1.2 laat zien dat er de afgelopen jaren ook enkele andere verschuivingen in de structuur van de werkgelegenheid in Limburg zijn opgetreden:

- Er was sprake van een toenemende vergrijzing en ontgroening van de werkzame bevolking: het werkgelegenheidsaandeel van jongeren is sinds 1997-1998 afgenomen, terwijl dat van ouderen is toegenomen. Deze ontwikkelingen golden sterker voor Limburg dan in Nederland als geheel.

- Door een grotere arbeidsmarktparticipatie nam het werkgelegenheidsaandeel van vrouwen steeds verder toe.

- De flexibilisering van de werkgelegenheid nam daarentegen niet verder toe. Een ontwikkeling die kan worden toegeschreven aan de toegenomen krapte op de arbeidsmarkt waardoor werkenden minder snel genoegen nemen met een tijdelijk contract en werkgevers ook sneller geneigd zijn hun werknemers aan zich te binden. Daarentegen nam het aantal deeltijders nog wel steeds meer toe. Deze ontwikkeling hangt deels samen met de toenemende participatie van (gehuwde) vrouwen.

- De verschuivingen in de werkgelegenheidsstructuur van de Limburgse economie lijken daarentegen tot stilstand te zijn gekomen. Deels is dit het gevolg geweest van de hoogconjunctuur, waardoor het werkgelegenheidsaandeel van de in Limburg sterk vertegenwoordigde industrie op peil is gebleven. De voortschrijdende verdienstelijking van de werkgelegenheid lijkt zich daardoor niet verder te hebben doorgezet.

Het percentage zelfstandigen is de laatste jaren constant gebleven. Er valt derhalve geen toenemend ondernemerschap onder de werkzame bevolking in Limburg te constateren. De ontwikkeling van het aantal zelfstandigen fungeert daardoor niet als een motor voor verdere economische groei in Limburg.

\section{Openstaande vacatures}

Zoals tabel 1.3 laat zien is het aantal openstaande vacatures door de gunstige groeicijfers aan het eind van de jaren negentig sterk toegenomen. In de anderhalf jaar tussen februari 1997 en juli 1998 is het aantal openstaande vacatures verdubbeld. Na een lichte daling in de daaropvolgende negen maanden, is er tot in 2000 weer een aanzienlijke stijging opgetreden. Mede als gevolg van de afremmende economische groei ligt het antal vacatures in 2001 echter op een wat lager niveau dan in de jaren daarvoor. Desalniettemin is het aantal openstaande vacatures nog veel groter dan vier jaar geleden in het eerste RAIL-rapport werd gemeten. 
Tabel 1.3

Ontwikkelingen aan de vraagzijde van de Limburgse arbeidsmarkt, 1997-2001

\begin{tabular}{|c|c|c|c|c|c|}
\hline Kenmerk & februari & juli & april & april & april \\
\hline & 1997 & 1998 & 1999 & 2000 & 2001 \\
\hline Aantal openstaande vacatures* & 8.100 & 16.200 & 14.300 & 17.100 & 14.500 \\
\hline Vacaturegraad (\%o) & 24 & 36 & 31 & 37 & 31 \\
\hline Langdurig openstaande vacatures (\%) & 27 & 32 & 31 & 36 & 51 \\
\hline
\end{tabular}

* Het aantal openstaande vacatures wordt bepaald door het aantal vacatures dat bij Arbeidsvoorziening wordt aangemeld te delen door het marktbereik van de vacaturemarkt in Limburg zoals dat naar voren komt uit de CBS vacature-enquête. Het aantal openstaande vacatures per marktsegment zoals dat in hoofdstuk 2 van dit rapport wordt gepresenteerd, is op vergelijkbare wijze bepaald.

Bron: Arbeidsvoorziening/CBS/ROA

Uitgedrukt als promillage van de werkgelegenheid, valt eenzelfde ontwikkeling te constateren: De vacaturegraad (zie Verklarende woordenlijst) is tussen 1997 en 2000 gestegen van $24 \%$ naar $37 \%$, maar daarna weer gedaald tot $31 \%$. Dit betekent dat er momenteel op iedere 1.000 werkenden 31 vacatures openstaan. Het is echter opmerkelijk dat het percentage langdurig openstaande vacatures in 2001 juist sterk is gestegen. Dit geeft aan dat het veel moeilijker is geworden personeel te vinden voor de vacante posities. Overigens kunnen de gepresenteerde cijfers mogelijk door meer factoren verklaard worden. Zo kan het zijn dat werkgevers vanwege de krapte op de arbeidsmarkt minder geneigd zijn hun personeelsproblematiek te vertalen in het willen aantrekken van nieuwe mensen. Men spreekt in dit verband wel van de 'discouraged employer'. Zoals in de volgende paragraaf zal worden aangegeven, is de daling van het aantal vacatures deels ook toe te schrijven aan de verbeterde aansluiting tussen vraag en aanbod op de arbeidsmarkt.

\section{Niet-werkende werkzoekenden}

Tabel 1.4 geeft een overzicht van de ontwikkeling van het aantal niet-werkende werkzoekenden (NWW) in Limburg vanaf februari 1997.2. Het aantal NWW blijkt in de afgelopen jaren sterk te zijn afgenomen. Het is opmerkelijk dat de daling van het aantal werkzoekenden, ondanks de afremming van de groei van de werkgelegenheid, tussen april 2000 en april in 2001 veel groter was dan in de twee daaraan voorafgaande jaren. Dit betekent ook dat het aantal openstaande vacatures in 2001 mede is gedaald vanwege een verbeterde aansluiting tussen vraag en aanbod op de arbeidsmarkt. Opmerkelijk is in dit verband ook dat het aantal langdurig werkzoekenden veel sterker is gedaald dan in de twee daaraan voorafgaande jaren. Het gaat hier om een daling met maar liefst $20 \%$ in één jaar tijd. Dit wijst er op dat het arbeidsmarktbeleid in Limburg succesvol is geweest. Dit wordt bevestigd door figuur 1.1, die laat zien dat het aantal langdurig werkzoekenden in 2001 evenals in de jaren daarvoor ook in procenten van het totaal aantal werkzoekenden verder is gedaald.

2 Na april 2001 is de daling van het aantal niet-werkende werkzoekenden overigens omgeslagen in een lichte stijging. 
Tabel 1.4

Ontwikkelingen aan de aanbodzijde van de Limburgse arbeidsmarkt, 1997-2001

\begin{tabular}{|c|c|c|c|c|c|}
\hline & $\begin{array}{r}\text { februari } \\
1997\end{array}$ & $\begin{array}{r}\text { juli } \\
1998\end{array}$ & $\begin{array}{r}\text { april } \\
1999\end{array}$ & $\begin{array}{r}\text { april } \\
2000\end{array}$ & $\begin{array}{r}\text { april } \\
2001\end{array}$ \\
\hline $\begin{array}{l}\text { Aantal niet-werkende werkzoekenden } \\
\text { Waarvan: }\end{array}$ & 59.400 & 43.200 & 43.000 & 39.700 & 33.000 \\
\hline $\begin{array}{l}\text { - langdurig werkzoekend } \\
\text { En waarvan: }\end{array}$ & 46.300 & 26.700 & 25.500 & 23.300 & 18.800 \\
\hline - fase 1 (direct bemiddelbaar) & 20.800 & 7.300 & 7.500 & 7.300 & 5.900 \\
\hline - fase 2 en 3 (afstand tot de arbeidsmarkt) & 19.600 & 20.200 & 18.300 & 15.500 & 13.500 \\
\hline - fase 4 (thans onbemiddelbaar) & 19.000 & 15.500 & 17.200 & 16.900 & 13.500 \\
\hline
\end{tabular}

Noot: zie voor meer informatie over de fase-indeling de Verklarende woordenlijst.

Bron: Arbeidsvoorziening/ROA

Arbeidsvoorziening deelt werkzoekenden ook in naar de mate van bemiddelbaarheid. Werkzoekenden in fase 1 kunnen daarbij worden beschouwd als direct bemiddelbaar, hetgeen betekent dat zij zonder begeleiding in staat moeten worden geacht een geschikte baan te vinden. Werkzoekenden in fase 2 en 3 hebben een grotere afstand tot de arbeidsmarkt. Veelal krijgen zij een begeleidingstraject aangeboden met als doel de toeleiding naar de arbeidsmarkt te vergemakkelijken. De bemiddelbaarheid van werkzoekenden in fase 4 is bijzonder problematisch. Voor deze groep werkzoekenden zijn naast begeleidingstrajecten vaak ook inspanningen gericht op maatschappelijke reïntegratie noodzakelijk. Werkzoekenden die zijn ingedeeld in fase 4 worden niet in staat geacht op korte termijn een volwaardige plaats op de arbeidsmarkt te verwerven.

Uit tabel 1.4 blijkt dat evenals in de voorafgaande jaren tussen april 2000 en april 2001 zowel het aantal minder goed bemiddelbaren werkzoekenden (ingedeeld in fase 2 en 3) als het aantal slecht bemiddelbare werkzoekenden (ingedeeld in fase 4) met enkele duizenden mensen gedaald. De zogenaamde 'harde kern' van de werkloosheid is hierdoor in vier jaar tijd met meer dan 10.000 mensen gedaald.

Het is zeer opmerkelijk dat ook het aantal werkzoekenden dat is ingedeeld in fase 4 aanzienlijk is gedaald. Uit de beschikbare cijfers kan niet worden opgemaakt in hoeverre deze daling toe te schrijven is aan het feit dat deze werkzoekenden, ondanks de verwachting dat zij op korte termijn geen volwaardige plaats op de arbeidsmarkı zouden kunnen verwerven, toch werk hebben gevonden. Het is ook mogelijk dat de daling vooral toe te schrijven is aan de doorstroom van slecht bemiddelbare werkzoekenden die een begeleidingstraject hebben gevolgd naar fase 2 en 3. 
Figuur 1.1

Ontwikkeling percentage langdurig werkzoekenden, Limburg, 1997-2001

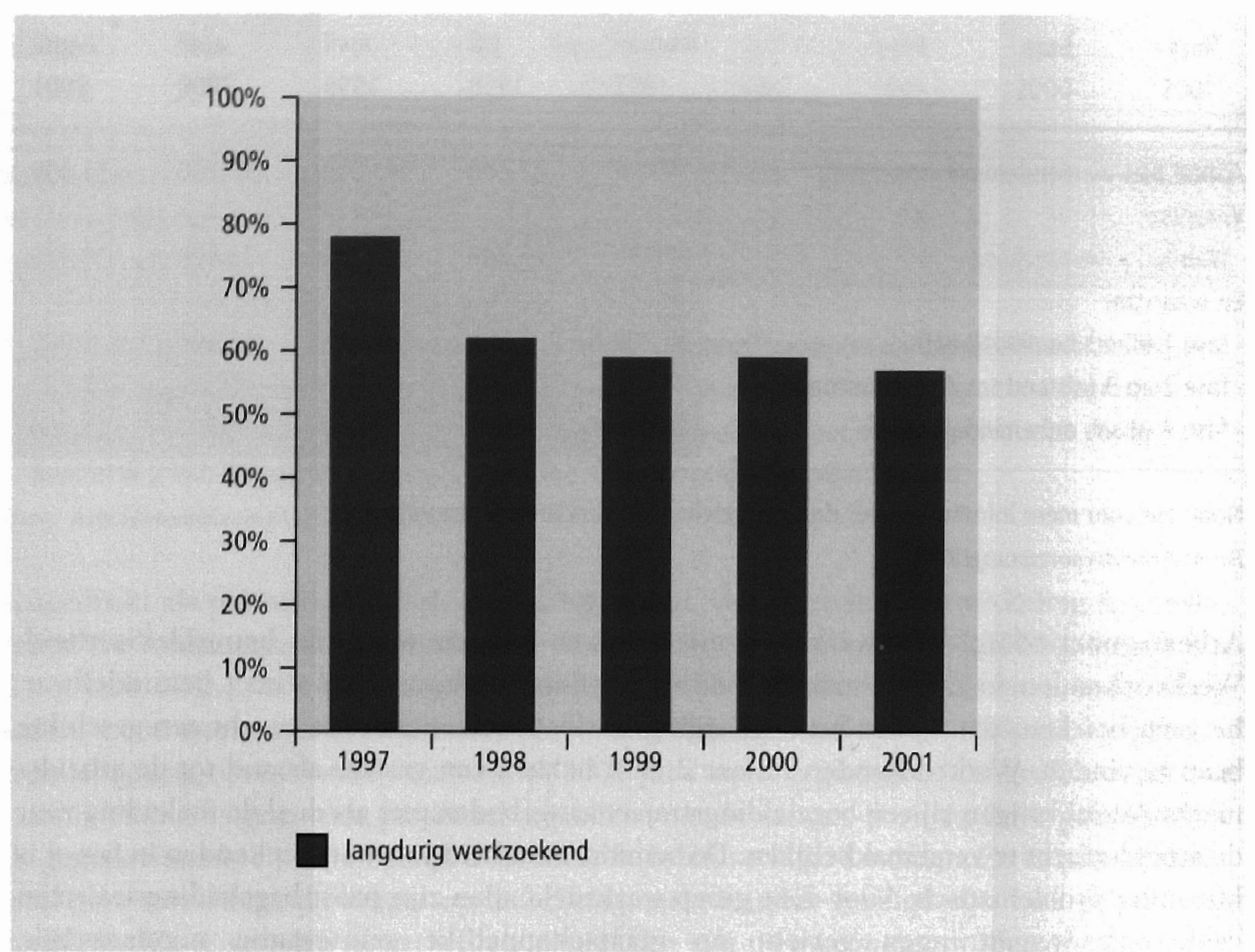

Bron: Arbeidsvoorziening/ROA

Overigens wijst ook de verdere daling van de direct bemiddelbare NWW in 2001 op een verbeterde aansluiting tussen vraag en aanbod op de arbeidsmarkt. De jaren daarvoor lag het aantal direct-bemiddelbare werkzoekenden rond de 7.500. Een aantal dat men zou kunnen beschouwen als een voor een goede allocatie op de arbeidsmarkt onvermijdbare frictiewerkloosheid van $1,5 \%$. Desalniettemin is deze frictiewerkloosheid toch verder gedaald tot $1,2 \%$.

De procentuele verdeling van de niet-werkende werkzoekenden over de verschillende fasen van bemiddelbaarheid is weergegeven in figuur 1.2. Daaruit komt naar voren dat het aandeel werkzoekenden in fase 1 na een sterke daling tussen februari 1997 en juli 1998 min of meer stabiel iets onder de $20 \%$ van het totale aantal NWW ligt. De daling in fase 1-werkzoekenden tussen februari 1997 en juli 1998 heeft vooral geleid tot een toename van het percentage werkzoekenden in fase $2 \mathrm{en} 3$. Het aandeel van deze groep was medio 1998 op het hoogste punt $(47 \%)$. Sindsdien is het aandeel teruggelopen tot de huidige $41 \%$. Het percentage werkzoekenden in fase 4 is na tussen 1997 en 2000 continu te zijn gestegen, in 2001 voor het eerst iets afgenomen. 
Figuur 1.2

Ontwikkeling fase-indeling niet-werkende werkzoekenden, Limburg, 1997-2001

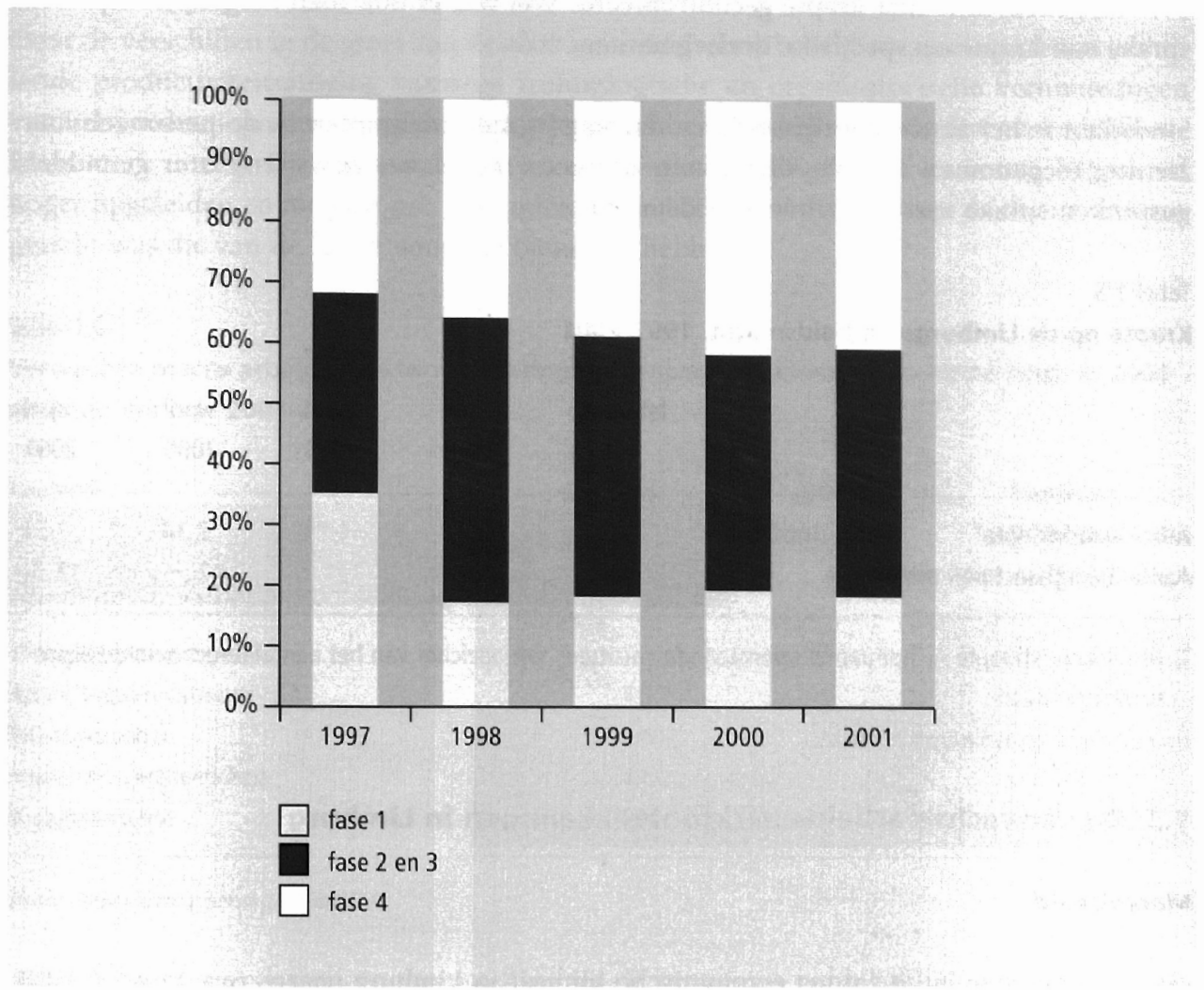

Bron: Arbeidsvoorziening/ROA

\section{Arbeidsmarktkrapte}

Tabel 1.5 schetst de ontwikkeling van de arbeidsmarktkrapte (zie Verklarende woordenlijst) tussen februari 1997 en april 2001 ${ }^{3}$. De tabel laat zien dat de krapte op de Limburgse arbeidsmarkı enorm is toegenomen. Tot april 2000 hing dit in belangrijke mate samen met een verdubbeling van het aantal openstaande vacatures. Ondanks de daling van hel aantal vacatures blijkt de arbeidsmarktkrapte in 2001 opnieuw groter te zijn geworden. In april 2001 stonden tegenover iedere 100 direct-bemiddelbare werkzoekenden maar liclst 251 openstaande vacatures. Dit verklaart ook het sterk toegenomen percentage van de vacatures dat langdurig openstaat. Het aantal direct bemiddelbare werkzoekenden is immers erg klein geworden. Bovendien kan vanwege het afnemende groeitempo van de economie ook de bereidheid van werkenden om elders een baan te gaan zoeken, zijn afgenomen. Immers, hel veranderen van baan brengt altijd enig risico met zich mee. Een risico dat men eerder bereid is te nemen in een hoogconjunctuur waarin het gemakkelijker is om bij een achteraf minder goed uitvallende baanverandering weer snel elders een goede baan te kunnen vinden.

$3 \mathrm{Na}$ april 2001 is de krapte op de arbeidsmarkt overigens enigszins afgenomen. 
De krapte blijkt zich sinds 1997 ook in een toenemend aantal arbeidsmarktsegmenten te manifesteren. Van de 13 onderscheiden bedrijfssectoren werd in 1997 geen enkele sector over de gehele linie met krapte geconfronteerd. Wel was er ook toen mogelijkerwijs reeds sprake van krapte op specifieke deelsegmenten.

Sindsdien is het aantal bedrijfssectoren dat kampt met knelpunten in de personeelsvoorziening toegenomen tot 12. Alleen voor de sector Landbouw en visserij is er gemiddeld gesproken sprake van een ruime arbeidsmarkt.

Tabel 1.5

Krapte op de Limburgse arbeidsmarkt, 1997-2001

\begin{tabular}{|c|c|c|c|c|c|}
\hline & februari & $\begin{array}{r}\text { juli } \\
1998\end{array}$ & $\begin{array}{c}\text { april } \\
1999\end{array}$ & $\begin{array}{r}\text { april } \\
2000\end{array}$ & $\begin{array}{r}\text { april } \\
2001\end{array}$ \\
\hline Arbeidsmarktkrapte* & 0,39 & 2,22 & 1,91 & 2,34 & 2,51 \\
\hline Aantal bedrijfssectoren met krapte & 0 & 11 & 12 & 12 & 12 \\
\hline
\end{tabular}

* Arbeidsmarktkrapte $=$ het aantal openstaande vacatures ten opzichte van het aantal direct-bemiddelbare werkzoekenden.

Bron: Arbeidsvoorziening/CBS/ROA

\subsection{De verwachte arbeidsmarktontwikkelingen in Limburg}

\section{Macrobeeld}

Ook de komende jaren zal het economische klimaat in Limburg naar verwachting redelijk gunstig blijven, al neemt de groei af. Zoals tabel 1.6 laat zien, vertaalt de economische groei in 2002 zich in een groei van de werkgelegenheid in Limburg ter grootte van $1,1 \%$. De totale groei over de middellange termijnperiode 2001-2006 bedraagt (circa) 4\% van de werkgelegenheid. Dit is equivalent met een gemiddelde jaarlijkse werkgelegenheidsgroei van $0,8 \%$. De verwachte werkgelegenheidsgroei in Limburg ligt daarmee iets lager dan landelijk. Een reden hiervoor is dat Limburg relatief meer werk biedt in conjunctuurgevoelige sectoren. De oververtegenwoordiging van deze sectoren - die eerder en heviger de gevolgen zullen voelen van een economische teruggang - remt de verwachte werkgelegenheidsgroei in Limburg.

In combinatie met een relatief hoge netto vervangingsvraag van $4,3 \%$, leidt de groei van de werkgelegenheid in 2002 tot een aantal baanopeningen voor schoolverlaters dat gelijk is aan $5,4 \%$ van het aantal werkenden. In de periode 2001-2006 is het aantal baanopeningen in totaal $30 \%$ (ofwel $5,4 \%$ gemiddeld per jaar). Dit aantal baanopeningen in Limburg komt overeen met het landelijke beeld voor de middellange termijn. Er zullen voor nieuwkomers op de Limburgse arbeidsmarkt in 2002 bijna 26.000 banen beschikbaar zijn. Tegenover een instroom van schoolverlaters van nog geen 23.000 , leidt dit tot een vraagoverschot van ongeveer 3.000 (ofwel 0,6\% van de totale werkgelegenheid in Limburg). Dit vraagoverschot is kleiner dan het verwachte vraagoverschot volgens de prognose voor het jaar 2001 uit het 
voorgaande RAIL-rapport. Desalniettemin blijft de verwachting dat de knelpunten op de Limburgse arbeidsmarkt ook de komende jaren nog groot blijven.

Door de verschillen in de groei van de afzet voor de diverse bedrijfssectoren en een verschillende productiviteitsstijging vanwege technologische en organisatorische vernieuwingen van het productieproces, loopt de werkgelegenheidsontwikkeling in de diverse bedrijfssectoren sterk uiteen. Dit was ook in het recente verleden het geval. Toen waren het vooral hoger opgeleiden en mensen met een opleidingsachtergrond die sterk op de dienstensector gericht was die van de groei voordeel bleken te hebbent.

Tabel 1.6

Verwachte macro arbeidsmarktontwikkeling (in procenten), Limburg en Nederland, in 2002 en in de periode 2001-2006

\begin{tabular}{lrrr} 
Kenmerk & $\begin{array}{r}\text { Limburg } \\
2002\end{array}$ & $\begin{array}{r}\text { Limburg } \\
2001-2006\end{array}$ & $\begin{array}{r}\text { Nederland } \\
2001-2006 \\
\%\end{array}$ \\
\hline Werkgelegenheidsgroei & 1,1 & 4 & $\%$ \\
Arbeidsmarktuitstroom & 4,3 & 26 & 24 \\
Baanopeningen & 5,4 & 30 & 30 \\
Instroom schoolverlaters & 4,8 & 24 & 25 \\
Vraagoverschot & 0,6 & 6 & 5 \\
\hline
\end{tabular}

Bron: Arbeidsvoorziening/CPB/ROA

Tabel 1.7 laat zien dat er - in tegenstelling tot de prognoses voor 2001, toen er slechts één bedrijfssector was waarvoor in Limburg een krimpende werkgelegenheid werd verwacht voor 2002 geldt dat er drie bedrijfssectoren een krimpende werkgelegenheid wordt verwacht: Landbouw en visserij, Chemie en Metaal en elehtrotechniek. Met uitzondering van de sector Energie wordt voor de andere bedrijfssectoren voor 2002 een toename van de werkgelegenheid verwacht. Met name voor de sectoren Handel, Transport en communicatie, Horeca, reparatie en zakelijke dienstverlening en Kwartaire diensten wordt een relatief hoge groei verwacht van $2,4 \%$ of meer.

Wanneer we kijken naar de verwachting op de middellange termijn dan valt op dat voor een aantal bedrijfssectoren een omslag in de werkgelegenheidsontwikkeling wordı verwacht. Verwacht wordt dat de Chemie zich op de middellange termijn herstelt van de werkgelegenheidskrimp in 2002. Omgekeerd wordt verwacht dat in de sector Overige industrie de groei op de middellange termijn omslaat in een daling. Opmerkelijk is ook de omslag voor de sector Bank-en verzekeringswezen. Voor deze bedrijfssector wordt na een jarenlange groei op de middellange termijn een krimpende werkgelegenheid verwacht.

4 Een en ander heeft ertoe geleid dat in de dienstensectoren de landelijke werkgelegenheid sinds 1987 met $46 \%$ is toegenomen, terwijl de werkgelegenheid in de industrie over dezelfde periode met $4 \%$-punten is afgenomen. Zie: N. Nahuis \& M. van Rooij, "De Invloed van de Dienstensector". Economisch Statistische Berichten, 5 mei 2000 , p. 382. 
Tabel 1.7

Ontwikkeling aantal werkenden per bedrijfssector (als percentage van de werkgelegenheid), Limburg en Nederland, in 2002 en in de periode 2001-2006

\begin{tabular}{lrrr} 
& $\begin{array}{r}\text { Limburg } \\
\text { Bedrifssector }\end{array}$ & $\begin{array}{r}\text { Limburg } \\
2001-2006\end{array}$ & $\begin{array}{r}\text { Nederland } \\
2001-2006\end{array}$ \\
& $\%$ & $\%$ & $\%$ \\
\hline Landbouw en visserij & $-2,6$ & -10 & -10 \\
Voeding & 0,1 & 4 & 4 \\
Chemie & $-0,2$ & 4 & -1 \\
Metaal en elektrotechniek & $-0,2$ & -1 & -4 \\
Overige industrie & 0,1 & -4 & 2 \\
Energie & $-0,0$ & 2 & 9 \\
Bouw en onroerend goed & 0,9 & 6 & 8 \\
Handel & 2,8 & 8 & 5 \\
Transport en communicatie & 2,5 & 4 & -2 \\
Bank- en verzekeringswezen & 2,3 & -2 & 14 \\
Horeca, reparatie en zakelijke dienstverlening & 2,0 & 11 & 7 \\
Kwartaire diensten & 2,4 & 5 & 5 \\
Overheid en onderwijs & 1,5 & 4 & 6 \\
Totaal & & & \\
\hline
\end{tabular}

Bron: Arbeidsvoorziening/CBS/CPB/ROA

\section{Beroepsklassen}

Tabel 1.8 laat de verwachte arbeidsmarktontwikkeling op de korte termijn zien voor de verschillende beroepsklassen. Ondanks de dalende werkgelegenheid in de bedrijfssector Landbouw en visserij zal naar verwachting in 2002 de werkgelegenheid in de Agrarische beroepen niet dalen. Alleen voor de Openbare orde- en veiligheidsberoepen wordt op korte termijn een krimpende werkgelegenheid verwacht ${ }^{5}$. De werkgelegenheidsgroei zal daarentegen bijzonder sterk zijn in de Medische en paramedische beroepen, de Sociaal-culturele beroepen en de Informaticaberoepen. De vervangingsvraag is voor de meeste beroepsklassen hoog, met uitzondering van de Culturele beroepen en de Informaticaberoepen. De lage vervangingsvraag in deze beroepsklassen kan worden verklaard door het relatief hoge percentage jongeren in deze beroepsklassen en het relatief lage percentage vrouwen.

De arbeidsmarktinstroom van schoolverlaters schommelt in 2002 bij de meeste beroepsklassen vrij dicht rond het gemiddelde van $4,9 \%$. Belangrijkste uitschieters zijn de

5 Ten aanzien van de Openbare orde- $e n$ veiligheidsberoepen moet de kanttekening worden gemaakt dat bij de prognoses geen rekening is gehouden met de mogelijke gevolgen voor de werkgelegenheid in deze beroepen van de sinds de aanslagen in de Verenigde Staten sterk toegenomen aandacht voor beveiliging en bewaking. Het valt echter moeilijk op voorhand te zeggen welk effect dit voor de Limburgse arbeidsmarkı kan hebben. 
Verzorgende en dienstverlenende beroepen met een hoge instroom $(5,8 \%)$ en de Pedagogische beroepen met een lage instroom van $3,6 \%$.

Wanneer de baanopeningen worden afgezet tegen de instroom, zien we dat voor alle beroepsklassen in 2002 grote knelpunten in de personeelsvoorziening kunnen worden verwacht.

Tabel 1.8

Arbeidsmarktprognoses per beroepsklasse (als percentage van de werkgelegenheid) en de knelpunten in de personeelsvoorziening, Limburg, 2002

\begin{tabular}{lrrrr} 
Beroepsklasse & $\begin{array}{r}\text { uitbreidings- } \\
\text { vraag } \\
\%\end{array}$ & $\begin{array}{r}\text { vervangings- } \\
\text { vraag } \\
\%\end{array}$ & $\begin{array}{r}\text { instroom } \\
\text { schoolverlaters } \\
\%\end{array}$ & ITKB* \\
\hline Pedagogische beroepen & 0,9 & 5,4 & 3,6 & 0,96 \\
Culturele beroepen & 0,6 & 2,9 & 4,5 & 0,98 \\
Agrarische beroepen & 0,1 & 5,3 & 4,8 & 0,92 \\
Technische en industrieberoepen & 0,4 & 4,6 & 4,5 & 0,97 \\
Transportberoepen & 0,7 & 5,4 & 4,9 & 0,99 \\
Medische en paramedische beroepen & 2,8 & 5,4 & 4,6 & 0,95 \\
Economisch-administratieve beroepen & 1,5 & 4,5 & 5,1 & 0,99 \\
Informaticaberoepen & 4,1 & 2,7 & 5,2 & 0,98 \\
Sociaal-culturele beroepen & 2,4 & 3,8 & 5,2 & 0,98 \\
Verzorgende en dienstverlenende beroepen & 1,1 & 5,6 & 5,8 & 0,96 \\
Openbare orde- en veiligheidsberoepen & $-1,6$ & 4,8 & 4,3 & 0,98
\end{tabular}

* ITKB = Indicator Toekomstige Knelpunten in de personeelsvoorziening naar Beroep. Deze indicator geeft aan in welke mate werkgevers problemen ondervinden bij het aantrekken van geschikt personeel. Naarmate de waarde van de ITKB lager is, zijn er meer knelpunten te verwachten (zie Verklarende woordenlijst).

Bron: Arbeidsvoorziening/CBS/CPB/ROA

Tabel 1.9 geeft een overzicht van de vraag- en aanbodkant van de Limburgse arbeidsmarkt in de periode 2001-2006. Dit middellange termijn beeld wijkt in één belangrijk opzicht af van dat van de korte termijn, namelijk dat er sprake is van krimpende werkgelegenheid voor meerdere beroepsklassen. Voor zowel de Pedagogische beroepen, Agrarische beroepen, Technische en industrieberoepen als de Openbare orde-en veiligheidsberoepen wordt voor de periode 2001-2006 een werkgelegenheidskrimp verwacht. Tabel 1.9 laat zien dat het perspectief voor de schoolverlaters echter in vrijwel alle beroepsklassen goed is. Alleen voor de Culturele beroepen zal het perspectief voor schoolverlaters iets minder gunstig worden. Daarentegen zijn de perspectieven voor degenen die werk zoeken in de Medische en paramedische beroepen op middellange termijn het gunstigst.

De middellange termijnvooruitzichten vanuit het perspectief van de werkgever, zijn iets minder somber dan op de korte termijn. Technische en industrieberoepen, Agrarische beroe- 
pen, Verzorgende en dienstverlenende beroepen en Culturele beroepen vertonen op de middellange termijn naar verwachting gemiddeld genomen geen grote knelpunten. Voor de Openbare orde- en veiligheidsberoepen worden zelfs vrijwel geen knelpunten in de personeelsvoorziening verwacht. De rekruteringsproblematiek voor deze beroepsklasse is dus naar verwachting vooral een korte termijn probleem.

Tabel 1.9

Arbeidsmarktprognoses per beroepsklasse (als percentage van de werkgelegenheid) en de knelpunten in de personeelsvoorziening, Limburg, in de periode 2001-2006

\begin{tabular}{lrrrr} 
Beroepsklasse & $\begin{array}{r}\text { uitbreidings- } \\
\text { vraag } \\
\%\end{array}$ & $\begin{array}{r}\text { vervangings- } \\
\text { vraag } \\
\%\end{array}$ & $\begin{array}{r}\text { instroom } \\
\text { schoolverlaters } \\
\%\end{array}$ & ITKB* \\
\hline Pedagogische beroepen & -1 & 24 & 17 & 0,95 \\
Culturele beroepen & 7 & 14 & 22 & 1,01 \\
Agrarische beroepen & -4 & 24 & 21 & 1,02 \\
Technische en industrieberoepen & -4 & 22 & 22 & 1,05 \\
Transportberoepen & 1 & 27 & 26 & 1,00 \\
Medische en paramedische beroepen & 11 & 24 & 22 & 0,91 \\
Economisch-administratieve beroepen & 9 & 21 & 26 & 0,98 \\
Informaticaberoepen & 16 & 14 & 26 & 0,98 \\
Sociaal-culturele beroepen & 19 & 18 & 27 & 0,94 \\
Verzorgende en dienstverlenende Beroepen & 2 & 27 & 29 & 1,01 \\
Openbare orde- en veiligheidsberaepen & -8 & 23 & 22 & 1,07 \\
& & & & \\
Totaal (inclusief hogere beroepen) & 4 & 23 & 25 & 1,00
\end{tabular}

* ITKB = indicator Toekomstige Knelpunten in de personeelsvoorziening naar Beroep. Deze indicator geeft aan in welke mate werkgevers problemen ondervinden bij het aantrekken van geschikt personeel. Naarmate de waarde van de ITKB lager is, zijn er meer knelpunten te verwachten (zie Verklarende woordenlijst).

Bron: Arbeidsvoorziening/CBS/CPB/ROA

\section{Opleidingssectoren}

Tabel 1.10 geeft een overzicht van vraag en aanbod in Limburg in 2002 voor de lagere en middelbare opleidingen. De tabel laat zien dat de schoolverlaters van VMBO Techniek, $V M B O$ Verzorging en alle opleidingen op het $\mathrm{MBO}$-niveau gunstige perspectieven hebben. Voor VMBO Verzorging geldt dit zelfs ondanks de verwachte werkgelegenheidskrimp. Schoolverlaters van de richtingen VMBO Economie, VMBO Theorie, HAVO/VWO, Basisonderwijs en met name VMBO Landbouw en natuurlijke omgeving hebben daarentegen minder gunstige perspectieven. Een achterblijvende uitbreidingsvraag, mede vanwege de upgrading van de kwalificatie-eisen in veel beroepen warin mensen met deze opleidingsachtergrond traditioneel emplooi vinden, is hier vooral debet aan. 
Tabel 1.10

Arbeidsmarktprognoses per opleidingssector (als percentage van de werkgelegenheid) en de arbeidsmarktperspectieven, Limburg, 2002

Opleidingssector

\begin{tabular}{rrrr}
$\begin{array}{r}\text { uitbreidings- } \\
\text { vraag }\end{array}$ & $\begin{array}{r}\text { vervangings- } \\
\text { vraag } \\
\%\end{array}$ & $\begin{array}{r}\text { instroom } \\
\text { schoolverlaters } \\
\%\end{array}$ & \\
\hline 0,3 & 4,8 & 5,5 & 1,01 \\
0,0 & 4,7 & 4,9 & 1,01 \\
0,3 & 2,1 & 7,5 & 1,06 \\
0,2 & 4,8 & 4,8 & 0,92 \\
0,0 & 2,7 & 6,9 & 1,05 \\
$-0,3$ & 6,4 & 6,7 & 0,98 \\
1,0 & 4,3 & 7,7 & 1,03 \\
0,4 & 3,0 & 4,1 & 1,00 \\
0,9 & 3,9 & 4,2 & 0,98 \\
1,2 & 4,0 & 4,6 & 0,97 \\
1,6 & 4,9 & 5,8 & 0,98 \\
1,1 & 4,3 & & \\
\hline
\end{tabular}

* ITA = Indicator Toekomstige Arbeidsmarktperspectieven. De ITA geeft de verhouding tussen aanbod en vraag in de prognoseperiode weer. Naarmate de waarde van de indicator hoger is, is het perspectief slechter (zie Verklarende woordenlijst).

Bron: Arbeidsvoorziening/CBS/CPB/ROA

Tabel 1.11 geeft een overzicht van de vraag- en aanbodkant van de Limburgse arbeidsmarkt in de periode 2001-2006 naar opleidingssector. De verwachte vervangingsvraag is voor de lagere opleidingen (tot en met het $\mathrm{VMBO}$ ) veelal niet groot genoeg om op te wegen tegen het aanbod van schoolverlaters van deze opleidingen. Daarentegen worden er gunstige perspectieven voor schoolverlaters van het $\mathrm{MBO}$ verwacht tegenover de minder gunstige perspectieven voor schoolverlaters met slechts Basisonderwijs of een VMBO-opleiding. Uitgesproken slecht zijn de vooruitzichten voor schoolverlaters van VMBO Landbouw en natuurlijke omgeving en VMBO Economie. De Limburgse werkgevers kunnen in de periode 2001-2006 naar verwachting vooral rekruteringsproblemen verwachten bij het vinden van geschikt personeel met een MBO-opleiding". Minder problemen in de personeelsvoorziening worden voorzien voor de lagere opleidingssectoren, met name VMBO Theoric, VMBO Techniek en VMBO Verzorging, terwijl bij het aantrekken van 'ongeschoold' personeel en mensen met VMBO Landbouw en natuurlijke omgeving en VMBO Economie de knelpunten op de arbeidsmarkı naar verwachting geheel zullen zijn verdwenen.

6 Aangenomen mag worden dat er ook veel knelpunten in de personeelsvoorziening voor hoger opgeleiden zullen worden ondervonden (Zie: De arbeidsmarkt naar opleiding en beroep tot 2006, ROA-R-2001/8. Maastricht, 2001). Omdat bij hoger opgeleiden veelal sprake is van een landelijke arbeidsmarkı, zijn hiervan geen vraag-aanbod vergelijkingen gemaakt voor de Limburgse arbeidsmarkt. 
Tabel 1.11

Arbeidsmarktprognoses per opleidingssector (als percentage van de werkgelegenheid) en de arbeidsmarktperspectieven, Limburg, in de periode 2001-2006.

\begin{tabular}{lrrrr} 
Opleidingssector & $\begin{array}{r}\text { uitbreidings- } \\
\text { vraag } \\
\%\end{array}$ & $\begin{array}{r}\text { vervangings- } \\
\text { vraag } \\
\%\end{array}$ & $\begin{array}{r}\text { instroom } \\
\text { schoolverlaters } \\
\%\end{array}$ & ITA* $^{*}$ \\
\hline Basisonderwijs & -23 & 27 & 28 & 1,01 \\
VMBO Theorie & -2 & 24 & 25 & 1,03 \\
VMBO Landbouw en natuurlijke omgeving & -32 & 11 & 38 & 1,26 \\
VMBO Techniek & -14 & 24 & 24 & 1,02 \\
VMBO Economie & -17 & 13 & 35 & 1,23 \\
VMBO Verzorging & -10 & 31 & 33 & 1,05 \\
HAVO/VWO & 14 & 22 & 38 & 1,03 \\
MBO Landbouw en natuurlijke omgeving & 15 & 14 & 21 & 0,94 \\
MBO Techniek & 6 & 19 & 21 & 0,97 \\
MBO Economie & 6 & 19 & 23 & 0,98 \\
MBO Dienstverlening en gezondheidszorg & 8 & 24 & 29 & 0,96 \\
& & & 24 & 0,97 \\
\hline Totaal (inclusief HBO en WO) & 4 & 21 & & \\
\hline
\end{tabular}

* ITA = Indicator Toekomstige Arbeidsmarktperspectieven. De ITA geeft de verhouding tussen aanbod en vraag in de prognoseperiode weer. Naarmate de waarde van de indicator hoger is, is het perspectief slechter (zie Verklarende woordenlijst).

Bron: Arbeidsvoorziening/CBS/CPB/ROA

\subsection{Knelpunten op de Limburgse arbeidsmarkt: Mogelijke oplossingen}

Uit de voorgaande paragrafen is duidelijk naar voren gekomen dat de knelpunten op de Limburgse arbeidsmarkt ook de komende jaren nog groot zullen blijven. Om te kijken in hoeverre er op deze knelpunten kan worden ingespeeld door het aanbod van werkenden te vergroten of verbeteren, kan de aandacht uitgaan naar een drietal groepen:

- de niet-werkende werkzoekenden;

- de stille reserve;

- de grenspendelaars.

\section{De niet-werkende werkzoekenden}

Uit tabel 1.12 blijkt dat slechts $18 \%$ van de niet-werkende werkzoekenden goed bemiddelbaar is ('fase l' volgens Arbeidsvoorziening, zie voor fase-indeling Verklarende woordenlijst). Zoals verwach mocht worden, heeft het overgrote deel van de werkzoekenden die niet direct inzetbaar zijn op de arbeidsmarkt een (te) lage opleidingsachtergrond. Van degenen die zijn ingedeeld in fase 4 heeft zelfs bijna 30\% slechts Basisonderwijs gevolgd. Daarnaast blijken mannen beter bemiddelbaar te zijn dan vrouwen. Vooral in de slechtst bemiddelbare categorie is dit verschil groot. Jongeren zijn ook beter bemiddelbaar dan ouderen. Er is echter een tamelijk groot percentage (18\%) oudere werkzoekenden dat goed bemiddelbaar is. 
Tabel 1.12

Niet-werkende werkzoekenden per fase van inzetbaarheid naar een aantal achtergrondkenmerken, Limburg, april 2001

\begin{tabular}{|c|c|c|c|c|}
\hline & fase 1 & fase 2 en 3 & fase 4 & totaal \\
\hline & $\%$ & $\%$ & $\%$ & $\%$ \\
\hline \multicolumn{5}{|l|}{ Geslacht: } \\
\hline Man & 52 & 50 & 46 & 49 \\
\hline Vrouw & 48 & 50 & 54 & 51 \\
\hline \multicolumn{5}{|l|}{ Leeftijd: } \\
\hline 15-29 jaar & 37 & 19 & 15 & 20 \\
\hline 30-49 jaar & 45 & 54 & 53 & 52 \\
\hline 50-64 jaar & 18 & 27 & 32 & 28 \\
\hline \multicolumn{5}{|l|}{ Opleidingscategorie: } \\
\hline - basisonderwijs & 8 & 16 & 29 & 20 \\
\hline - lager & 55 & 56 & 51 & 54 \\
\hline - middelbaar & 32 & 25 & 17 & 23 \\
\hline - hoger & 3 & 2 & 2 & 2 \\
\hline - wetenschappelijk & 2 & 1 & 1 & 1 \\
\hline Totaal & 100 & 100 & 100 & 100 \\
\hline Aantal & 5.900 & 13.500 & 13.500 & 33.000 \\
\hline
\end{tabular}

Bron: Arbeidsvoorziening/ROA

\section{De stille reserve}

De 'stille reserve' van mensen die zich niet actief aanbieden op de arbeidsmarkt was in Limburg in 1999 circa 210.000 mensen. Overigens ongeveer 20.000 mensen minder dan 5 jaar daarvoor ${ }^{7}$. Het is een interessant gegeven dat vrijwel alle niet-participerenden werkervaring hebben. Deze werkervaring wordt door werkgevers in bepaalde branches hoger gewaardeerd dan het niveau of de richting van de gevolgde opleiding ${ }^{\sharp}$. Hoewel het grootste gedeelte van de niet-participerenden lager opgeleid is, kan deze stille reserve dus wel degelijk voor werkgevers een belangrijke bron zijn om nieuw personeel uit te werven.

Om de stille reserve te stimuleren de arbeidsmarkt te betreden, wordt in hoofdstuk 5 van dit rapport gekeken naar de belemmeringen die men in de praktijk ondervindt om te kunnen gaan werken en naar de redenen waarom men gestopt is met werken. Hieruit komı

7 Er wordt hier gebruik gemaakı van de cijfers voor 1999 om consistent te zijn met hoofdstuk 5 , waar de niet-participerenden worden opgesplitsı naar beschikbaar en niet beschikbaar. Deze opsplitsing is voor het jaar 2000 niet mogelijk. $\mathrm{Na} 1999$ is de stille reserve in Limburg overigens verder gedaald.

8 W. Smits (2001). Wie willen werkgevers? Personeelsselectie in de Zorg, de Metaalindustrie en de IT, ROA-W2001/2. Maastricht. 
naar voren dat de meeste gestopt zijn met werken vanwege werkzaamheden in het huishouden of vanwege ziekte. Daarnaast blijkt dat een grote groep de zorg draagt voor de opvoeding van de eigen kinderen, of andere zorgtaken heeft. Deze zorgtaken beschouwt men zelf vaak als een belemmering om weer betaald werk te kunnen verrichten. Om deze mensen te stimuleren om te gaan werken, kunnen zowel overheid als werkgevers trachten deze belemmeringen weg te nemen door bijvoorbeeld de wachttijden voor kinderopvang te verkleinen, de prijs van kinderopvang te verlagen en kinderopvang regelingen op de werkplek aan te bieden. Met name op arbeidsmarktsegmenten waar veel vrouwen werkzaam zijn, zou dit een belangrijke bijdrage kunnen leveren aan het verminderen van de knelpunten op de Limburgse arbeidsmarkt.

\section{Grenspendelaars}

Vanwege de geografische ligging van Limburg, speelt naast het onbenutte arbeidspotentieel in de provincie zelf, ook het potentiële arbeidsaanbod vanuit de aangrenzende regio's in België en Duitsland een rol. De feitelijke arbeidsmarktsituatie verschilt immers duidelijk tussen de regio's. Zo is er in het aangrenzende België en Duitsland sprake van een aanbodsoverschot, terwijl Limburg juist een vraagoverschot kent?

Grenspendel is - economisch gezien - met name aantrekkelijk wanneer er in de ene regio een aanbodsoverschot voor een bepaald beroep bestaat, terwijl de andere regio een vraagoverschot voor dat beroep kent. In de Euregio Rijn-Maas-Noord (waartoe Noord-en Midden-Limburg behoren) is dit met name het geval bij de Technische- en industrieberoepen, Openbare orde- en veiligheidsberoepen, Pedagogische beroepen en Agrarische beroepen. In de Euregio Maas-Rijn (waaronder Zuid-Limburg valt) doet deze situatie zich vooral voor in de Culturele beroepen en de Openbare orde- en veiligheidsberoepen.

Helaas is er weinig informatie beschikbaar over de belangstelling onder de werkzoekenden, e.a. uit deze regio's om in Limburg te gaan werken. Wel kan een beeld gegeven worden van de ontwikkeling van de omvang en samenstelling van de pendelstromen van en naar het aangrenzende buitenland. Uit tabel 1.13 blijkt dat de grenspendel van en naar Limburg niet erg omvangrijk is. Er blijken meer Limburgers in België of Duitsland te werken dan dat er mensen van deze landen in Limburg komen werken. Van additioneel aanbod uit de aangrenzende regio's is per saldo dan ook geen sprake. Wel is er een opmerkelijke toename van de grenspendel uit Duitsland naar Limburg. Bovendien is er duidelijk sprake van een afname van het aantal Limburgse grensarbeiders die in Duitsland werken. Daarentegen blijken de pendelstromen vanuit en naar België zich in omgekeerde richting te ontwikkelen. Opvallend is in dit verband vooral de toename van de grensarbeiderstroom vanuit Limburg naar België.

9 De hier vermelde uitkomsten komen uit het rapport Naar de arbeidsmarkt zonder grenzen: eerste ontwikkeljaar, ETII/ROA, Maastricht, 2002. 
Tabel 1.13

Omvang van de grensarbeid tussen Limburg, België en Duitsland, april 1994 en april 2000

$1994 \quad 2000$

\begin{tabular}{lrr}
\hline Vanuit Limburg naar België & 900 & 1.270 \\
Vanuit België naar Limburg & 6.370 & 6.330 \\
Pendelsaldo Limburg-België & 5.470 & 5.060 \\
& & \\
Vanuit Limburg naar Duitsland & 10.160 & 8.490 \\
Vanuit Duitsland naar Limburg & 600 & 1.540 \\
Pendelsaldo Limburg-Duitsland & -9.560 & -6.950 \\
& & -1.890 \\
\hline
\end{tabular}

Bron: Statistiek Grensarbeid, CBS

Uit cijfers van het CBS blijkt dat grenspendelaars met name jongeren en mannen zijn. Wel neemt het percentage vrouwen in de pendel tussen Belgiê en Limburg de laatste jaren toe. Er zijn aanwijzingen dat het opleidingsniveau van pendelaars vrij laag is, maar harde cijfers hierover ontbreken. Dat de afstand tussen woon- en werkplaats bij pendel een rol speelt, blijkt uit de geografische spreiding van de grenspendel. Hierin vervult Zuid-Limburg, centraal gelegen tussen Belgisch Limburg en de regio Aken een sleutelrol. Belgische grenspendelaars werken vooral in de Limburgse gezondheids- en welzijnszorg en in de autoindustrie, terwijl Duitse pendelaars veel in de detailhandel te vinden zijn.

Uit onderzoek ${ }^{10}$ blijkt dat in het algemeen problemen met verblijfsrechten, de toegang tot bepaalde beroepen (eisen in de publieke sector, diploma erkenning), informatievoorziening over vraag en aanbod op de Europese arbeidsmarkt en het gebrek aan grensoverschrijdende pensioenfondsen de belangrijkste belemmeringen vormen voor de mate waarin grensarbeid een substantiële bijdrage kan leveren aan het verminderen van de tekorten op de arbeidsmarkt in het aangrenzende buitenland. Voor Duitsers zijn het lagere loonpeil in Limburg, vooroordelen en taalproblemen belangrijke redenen om niet in Nederland te werken. De belangrijkste hindernis voor hen blijkt echter het gebrek aan Euregionale arbeidsmarktinformatie te zijn. Voor Belgen zijn de verschillen in het belasting-en sociale zekerheidstelsel belangrijke hinderpalen om in Nederland te gaan werken". Ook voor de Belgen blijkı echter het gebrek aan goede informatie over hun arbeidsmarktperspectieven in het aangrenzende buitenland het belangrijkste probleem te zijn.

Niet alleen werkzoekenden, maar ook werkgevers hebben behoefte aan betere Euregionale arbeidsmarktinformatie. In dit kader kan het onlangs gestarte 'Grensinfopun' in Heerlen een belangrijke stimulans vormen. Het 'Grensinfopunt' is een samenwerkingsverband

10 Sociaal-Economische Raad (2001), Arbeidsmobiliteit in de EU, SER-Advies 01-04, Den Haag.

11 Overigens hebben er op dit punt de laatste jaren belangrijke veranderingen plaatsgevonden, doordat er een nieuw belastingverdrag tussen Belgiē en Nederland is gesloten. Dit zou de grenspendel ıussen beide landen moeten bevorderen. 
DE LMBURGSE ARBEIDSMARKT 2001-2006

tussen verschillende Nederlandse ministeries en de provincie Limburg, en zal in de toekomst mogelijk versterkt worden met buitenlandse partners uit de grensregio's. Via dit 'Grensinfopunt' kunnen particulieren, ondernemingen en organisaties op één plek terecht met vragen over bijvoorbeeld sociale zekerheid, kinderbijslag en werkloosheid.

Overigens is naast de inkomende pendel van grensarbeiders ook de instroom van arbeidskrachten uit niet EU-landen van enig belang voor de Limburgse economie. Zo blijkt uit de Rapportage uitvoering wet arbeid vreemdelingen dat vooral in de Land- en tuinbouw (531 personen) en in de Zakelijke dienstverlening (219 personen) veel vergunningen worden verleend aan buitenlanders om in Limburg te gaan werken. 


\section{De arbeidsmarktpositie van MBO-schoolverlaters in Limburg}

In Limburg volgen ruim 26.000 leerlingen een MBO-opleiding. MBO Economie is daarbij veruit de grootste richting. Ruim eenderde van de leerlingen volgt de meer op het leren in de beroepspraktijk gerichte Beroepsbegeleidende leerweg (BBL). Deze meer praktisch georiênteerde leerweg wordt vooral vaak door de leerlingen van MBO Techniek gevolgd.

MBO Techniek wordt met name door mannen gevolgd. Dit geldt het sterkst voor de BBL. Slechts 1 op de veertig leerlingen is hier een vrouw. MBO Dienstverlening en gezondheidszorg is daarentegen de typische 'vrouwen'-sector binnen het MBO.

Bijna de helft van het aantal gediplomeerden in het $M B O$ heeft een opleidingsachtergrond $M B O$ Economie. Tweederde daarvan heeft een BOL opleiding gevolgd. Daarentegen heeft van de gediplomeerden van MBO Techniek ruim driekwart een BBL-opleiding gevolgd. Hoewel met de momenteel beschikbare cijfers geen harde uitspraken gedaan kunnen worden over de voortijdige uitval van leerlingen, wijzen de beschikbare gegevens op een relatief grote leerlingenuitval bij de BOL-opleidingen in de sector MBO Techniek en de BBL-opleidingen in de sector MBO Dienstverlening en gezondheidszorg.

De verbetering in de arbeidsmarktpositie van de schoolverlaters van het MBO van de afgelopen jaren heeft zich tussen 1999 en 2000 in Limburg niet voortgezet. De werkloosheid heeft zich op hetzelfde lage niveau van $2 \%$ gestabiliseerd. Ook de sterke stijging van de starterslonen heeft zich niet voortgezet. Er zijn echter wel duidelijke verschillen tussen de diverse opleidingsrichtingen. Voor de schoolverlaters met een opleiding MBO Techniek zijn de ontwikkelingen het gunstigst. De (intrede)werkloosheid neemt voor deze opleidingssector verder af, het gemiddelde bruto maandloon stijgt en men vindt vaker werk op het eigen niveau en in de eigen vakrichting. Voor schoolverlaters met een opleiding MBO Dienstverlening en gezondheidszorg is de arbeidsmarktpositie in Limburg - in tegenstelling tot de ontwikkelingen op landelijk niveau - tussen 1999 en 2000 daarentegen op een aantal punten duidelijk verslechterd.

\subsection{Inleiding}

In dit hoofdstuk zal een overzicht worden gegeven van de huidige arbeidsmarktsituatie voor MBO-schoolverlaters in Limburg. Ook zal op basis van de beschikbare informatie bij de vier ROC's in Limburg een overzicht worden gegeven van het aantal leerlingen en het aantal gediplomeerden in de vier onderwijssectoren die binnen het MBO kunnen worden onderscheiden. Hierbij zal een onderscheid gemaakt worden tussen de leerlingen en gediplomeerden van de BeroepsOpleidende Leerweg (BOL) en de BeroepsBegeleidende Leerweg (BBL).

In paragraaf 2.2 geven we om te beginnen een overzicht van actuele leerlingenaantallen en aantallen gediplomeerden van het AOC en de ROC's in Limburg. Vervolgens wordı in paragraaf 2.3 bekeken welke veranderingen er in Limburg in de afgelopen jaren hebben plaatsgevonden in de arbeidsmarktpositie van de schoolverlaters van het $\mathrm{MBO}$. Het gaat hier om zowel de situatie op de arbeidsmarkt, weergegeven door (intrede)werkloosheidspercentages en het bruto maandloon, als ook om de "verborgen discrepanties", Van verborgen discre- 
panties is bijvoorbeeld sprake als schoolverlaters werk moeten accepteren beneden hun niveau of buiten hun vakgebied, vaker een tijdelijke in plaats van een vaste aanstelling krijgen, of vaker genoegen moeten nemen met deeltijdwerk, terwijl men liever een fulltime betrekking zou willen hebben.

\subsection{Leerlingenaantallen en gediplomeerden van het MBO in Limburg}

Tabel 2.1 geeft een overzicht van het aantal leerlingen in de vier onderscheiden onderwijssectoren van het $\mathrm{MBO}$ in Limburg. Het gaat hier om het door de overheid bekostigde aantal leerlingen in oktober 2000. Het blijkt dat er in totaal ruim 26.000 leerlingen een MBOopleiding volgen. Ruim eenderde van de leerlingen volgt de meer op het leren in de beroepspraktijk gerichte BeroepsBegeleidende Leerweg (BBL). Deze meer praktisch georiënteerde leerweg wordt vooral vaak door de leerlingen van de technische richting MBO Techniek gevolgd. Bij MBO Techniek zijn er zelfs meer leerlingen die deze BBL volgen dan leerlingen die de BeroepsOpleidende Leerweg (BOL) volgen. Bij MBO Economie en MBO Dienstverlening en gezondheidszorg is het aantal leerlingen dat de BOL volgt daarentegen meer dan twee keer zo groot als het aantal BBL-leerlingen.

Tabel 2.1

Aantal (bekostigde) leerlingen van het MBO in Limburg naar onderwijssector, oktober 2000

\begin{tabular}{|c|c|c|c|}
\hline \multirow[b]{2}{*}{ Opleidingssector } & \multicolumn{3}{|c|}{ Aantal leerlingen } \\
\hline & $\mathrm{BOL}$ & $\mathrm{BBL}$ & Totaal \\
\hline MBO Landbouw en natuurlijke omgeving & 667 & 396 & 1.063 \\
\hline MBO Techniek & 3.274 & 3.925 & 7.199 \\
\hline MBO Dienstverlening en gezondheidszorg & 5.529 & 2.271 & 7.800 \\
\hline MBO Economie & 7.158 & 3.267 & 10.425 \\
\hline Totaal & 16.628 & 9.859 & 26.487 \\
\hline
\end{tabular}

Bron: ROCs Limburg

Helaas is het vanwege de invoering van de WEB momenteel nog niet mogelijk de ontwikkeling van de leerlingenaantallen in de verschillende $\mathrm{MBO}$-sectoren in Limburg in beeld te brengen $^{12}$. Alleen voor de opleidingssector MBO Landbouw en natuurlijke omgeving zijn cijfers beschikbaar voor de jaren 1998 en 1999. Hieruit blijkt dat het aantal leerlingen in deze sector de laatste jaren stabiel is gebleven.

Zoals bekend, zijn er in het MBO grote traditionele verschillen in de opleidingskeuze van mannen en vrouwen. Het grootste verschil doet zich voor tussen MBO Techniek en MBO Dienstverlening en gezondheidszorg. MBO Technick wordt met name door mannen gevolgd. Dit geldt het sterkst voor de BBL. Bij de BOL is nog $10 \%$ van de leerlingen een vrouw (zie tabel 2.2). Bij de BBL is dit slechts 2,5\%. MBO Dienstverlening en gezondheidszorg is daar-

12 Aangenomen mag worden dat dit in het volgende RAlL-rapport wel mogelijk is wanneer we kunnen beschikken over de leerlingaantallen voor het jaar 2001 
entegen de typische 'vrouwen'-sector binnen het MBO, al is hier het percentage mannen wel veel hoger dan het percentage vrouwen bij de technische opleidingen. Overigens geldt ook hier weer dat de verschillen bij de BBL groter zijn dan bij de BOL.

De sector MBO Economie, die de grootste sector vormt binnen het $\mathrm{MBO}$, is even populair bij de mannen als bij de vrouwen. Daarbij blijken vrouwen iets vaker voor een BBL-opleiding te kiezen en mannen juist iets vaker voor een BOL-opleiding.

Tabel 2.2

Aantal (bekostigde) leerlingen van het MBO in Limburg naar onderwijssector, verbijzonderd naar geslacht, oktober 2000

\begin{tabular}{lrrrrr} 
& \multicolumn{3}{c}{ Aantal leerlingen } \\
Opleidingssector & \multicolumn{2}{c}{ BOL } & \multicolumn{2}{c}{ BBL } \\
& mannen & vrouwen & mannen & vrouwen \\
\hline MBO Landbouw en natuurlijke omgeving* & 2.987 & 287 & 3.834 & 91 \\
MBO Techniek & 1.154 & 4.375 & 352 & 1.919 \\
MBO Dienstverlening en gezondheidszorg & 3.602 & 3.556 & 1.596 & 1.671 \\
MBO Economie & & & & \\
Totaal (excl. MBO Landbouw en natuurlijke omgeving) & 7.743 & 8.218 & 5.782 & 3.681 \\
\hline
\end{tabular}

* Niet beschikbaar uitgesplitst naar geslacht.

Bron: ROC's Limburg

Tabel 2.3 geeft een overzicht van het aantal gediplomeerden in Limburg in de verschillende sectoren binnen het MBO. Uit deze cijfers blijkt dat bijna de helft van het aantal gediplomeerden een opleidingsachtergrond MBO Economie heeft. Tweederde daarvan heeft een BOL-opleiding gevolgd. Bij de sector MBO Dienstverlening en gezondheidszorg ligt het percentage gediplomeerden dat een BOL-opleiding heeft gevolgd zelfs nog hoger. Daarentegen heeft van de gediplomeerden van de sector MBO Technick ruim driekwart een BBL-opleiding gevolgd. Dit illustreert dat met name de sector techniek nog steeds sterk geworteld is in de BBL.

Met name het aantal gediplomeerden bij de BOL-opleidingen in de sector MBO Technick is erg laag. Hoewel met de momenteel beschikbare cijfers geen harde uitspraken gedaan kunnen worden over de voortijdige uitval van leerlingen, wijst dit toch in de richting van een veel grotere leerlingenuitval dan bij de BOL-opleidingen in de andere sectoren. Daarentegen blijkt bij de BBL-opleidingen het aantal gediplomeerden in de sector MBO Dienstverlening en gezondheidszorg, gezien het aantal BBL-leerlingen in deze sector, erg laag te zijn. Ook dit wijst op een mogelijk relatief hoge uitval van ongediplomeerde lecrlingen. 
DE LMEURGSE ARBEIDSMARKT 2001-2006

Tabel 2.3

Aantal gediplomeerden van het MBO in Limburg naar onderwijssector, kalenderjaar 2000

\begin{tabular}{lrrr} 
& \multicolumn{3}{c}{ Aantal gediplomeerden } \\
Opleidingssector & BOL & BBL & Totaal \\
\hline MBO Landbouw en natuurlijke omgeving & 217 & 159 & 376 \\
MBO Techniek & 266 & 866 & 1.132 \\
MBO Dienstverlening en gezondheidszorg & 1.118 & 361 & 1.479 \\
MBO Economie & 1.684 & 850 & 2.534 \\
& & & \\
Totaal & 3.285 & 2.236 & 5.521 \\
\hline
\end{tabular}

Bron: ROC's Limburg

\subsection{Arbeidsmarktpositie van MBO-schoolverlaters}

In deze paragraaf zal een beeld worden geschetst van de actuele arbeidsmarktpositie van MBO-schoolverlaters. We beperken ons hierbij tot schoolverlaters van de initiële opleidingen in het MBO van de vier ROC's in Limburg. We geven in deze paragraaf een overzicht van de ontwikkeling van de arbeidsmarktpositie van de schoolverlaters in de periode 1997$2000^{13}$. Hierbij kijken we zowel naar de situatie op de arbeidsmarkt (het werkloosheidspercentage en het bruto maandloon), als ook naar de verborgen aansluitingsproblemen: het moeten accepteren van werk beneden het eigen niveau of buiten het eigen vakgebied, vaker een tijdelijke in plaats van een vaste aanstelling krijgen, of vaker genoegen moeten nemen met deeltijdwerk, terwijl men liever een fulltime betrekking zou willen hebben. De cijfers over de Limburgse schoolverlaters worden telkens vergeleken met de cijfers voor Nederland als geheel. Tevens zal telkens worden aangegeven in hoeverre het beeld voor bepaalde opleidingssectoren afwijkt van de situatie voor het gehele MBO in Limburg ${ }^{1+}$

\subsubsection{Open discrepanties}

Aansluitingsproblemen op de arbeidsmarkt kunnen zich op verschillende manieren manifesteren. In deze paragraaf wordt de aandacht allereerst gericht op de (intrede)werkloosheid en het gemiddelde brutoloon onder MBO-schoolverlaters. Het werkloosheidspercentage en het verdiende loon in een bepaald marktsegment geeft een indicatie van de zogenaamde open discrepanties tussen vraag en aanbod op de arbeidsmarkt.

13 De cijfers in deze paragraaf zijn afkomstig uit het Schoolverlaters informatie Systeem (SIS) van het ROA Ze dienen met enige voorzichtigheid betracht te worden, daar niet alle Limburgse ROC's gedurende alle jaren aan de enquêtes hebben deelgenomen.

14 De figuren in het vervolg van deze paragraal hebben betrekking op het totale MBO. Voor cen overzich van de informatie voor het jaar 2000 naar onderliggende opleidingsector, zie: tabellen 2.13 tot en met 2.19 van de Statistische Bijlage. 


\section{Werkloosheid}

In figuur 2.1 is weergegeven in hoeverre er tussen 1997 en 2000 veranderingen zijn opgetreden in de werkloosheid onder MBO-schoolverlaters. De werkloosheid onder schoolverlaters is het aantal werklozen uitgedrukt als percentage van het aantal schoolverlaters met een bepaalde opleidingsachtergrond. Te zien is dat zowel voor Limburg als voor Nederland als geheel het werkloosheidspercentage tussen 1999 en 2000 onveranderd op het lage niveau van $2 \%$ is blijven staan. Er is daarmee een einde gekomen aan de gestage daling die in de voorgaande jaren was waargenomen.

Landelijk vertoont alleen MBO Dienstverlening en gezondheidszorg tussen 1999 en 2000 nog een daling van het werkloosheidspercentage (van $2 \%$ naar $1 \%$ ). In Limburg is de werkloosheid alleen gedaald voor de opleidingssector MBO Techniek (van 3\% naar 2\%). De sterkste daler in Limburg tussen 1998 en 1999, MBO Economie, ziet zich nu weer geconfronteerd met een stijging van $1 \%$ naar $2 \%$. Voor de intreders op de arbeidsmarkt blijven dit overigens allemaal erg lage werkloosheidspercentages, die grotendeels gezien kunnen worden als een onvermijdbare frictiewerkloosheid (zie Verklarende woordenlijst).

Figuur 2.1

Werkloosheid (in procenten) onder MBO-schoolverlaters, Limburg en Nederland, 1997-2000

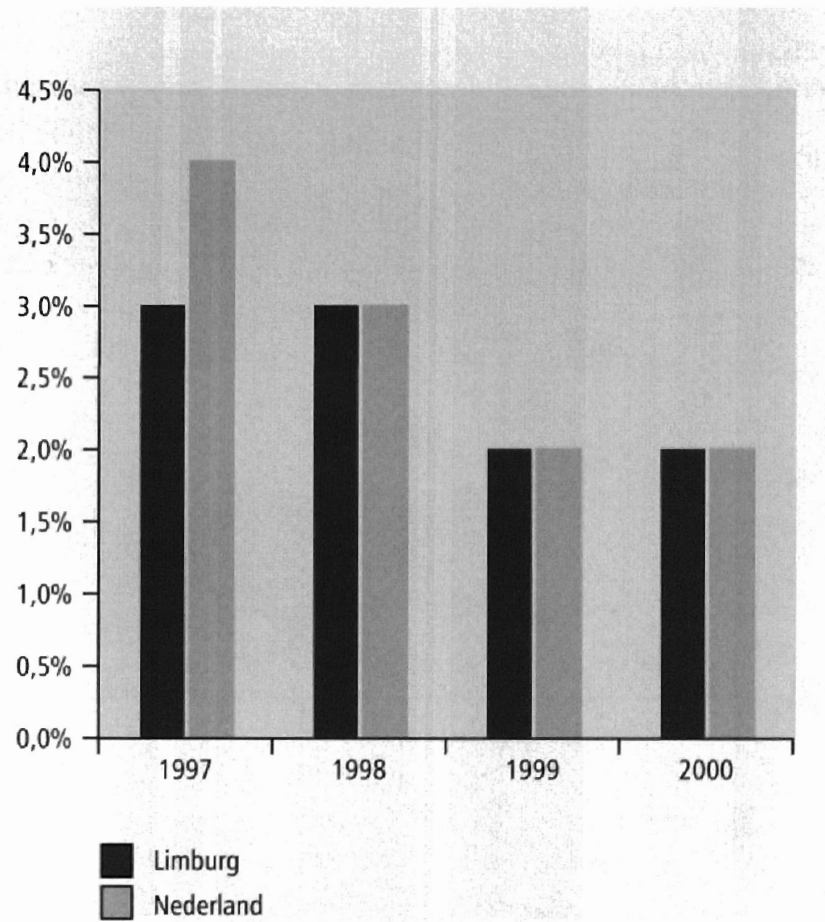

Bron: $R O A$

Figuur 2.2 laat de ontwikkeling zien in de intredewerkloosheid, dat wil zeggen: in het percentage schoolverlaters dat na het verlaten van de opleiding ten minste 4 maanden op 
zoek is geweest naar een baan. Ook de daling van de intredewerkloosheid is in Limburg duidelijk over haar hoogtepunt heen. Het percentage bedraagt onveranderd $4 \%$. Daarmee is de werkloosheid direct na het schoolverlaten ongeveer twee maal zo hoog als de werkloosheid ruim een jaar na het verlaten van het onderwijs. Dit wijst er nogmaals op dat er hier voor een belangrijk deel sprake is van frictiewerkloosheid die samenhangt met de tijd waarmee het zoeken naar een passende baan vaak gepaard gaat. De iets gunstigere economische ontwikkeling voor Nederland als geheel heeft er waarschijnlijk voor gezorgd dat de intredewerkloosheid landelijk toch nog verder is gedaald. Het landelijke percentage komt voor 2000 uit op 3\%. De grootste afname van de intredewerkloosheid kwam voor zowel Limburg als Nederland echter voor in de periode 1996-1998.

In Limburg is de intredewerkloosheid voor MBO Techniek gehalveerd van 6\% naar 3\%. Ook op landelijk niveau daalde de intredewerkloosheid onder de schoolverlaters in deze sector. Daarentegen is de intredewerkloosheid in de sector MBO Dienstverlening en gezondheidszorg meer dan verdubbeld van $2 \%$ naar $5 \%$.

Figuur 2.2

Intredewerkloosheid (in procenten) onder MBO-schoolverlaters, Limburg en Nederland, 1997-2000

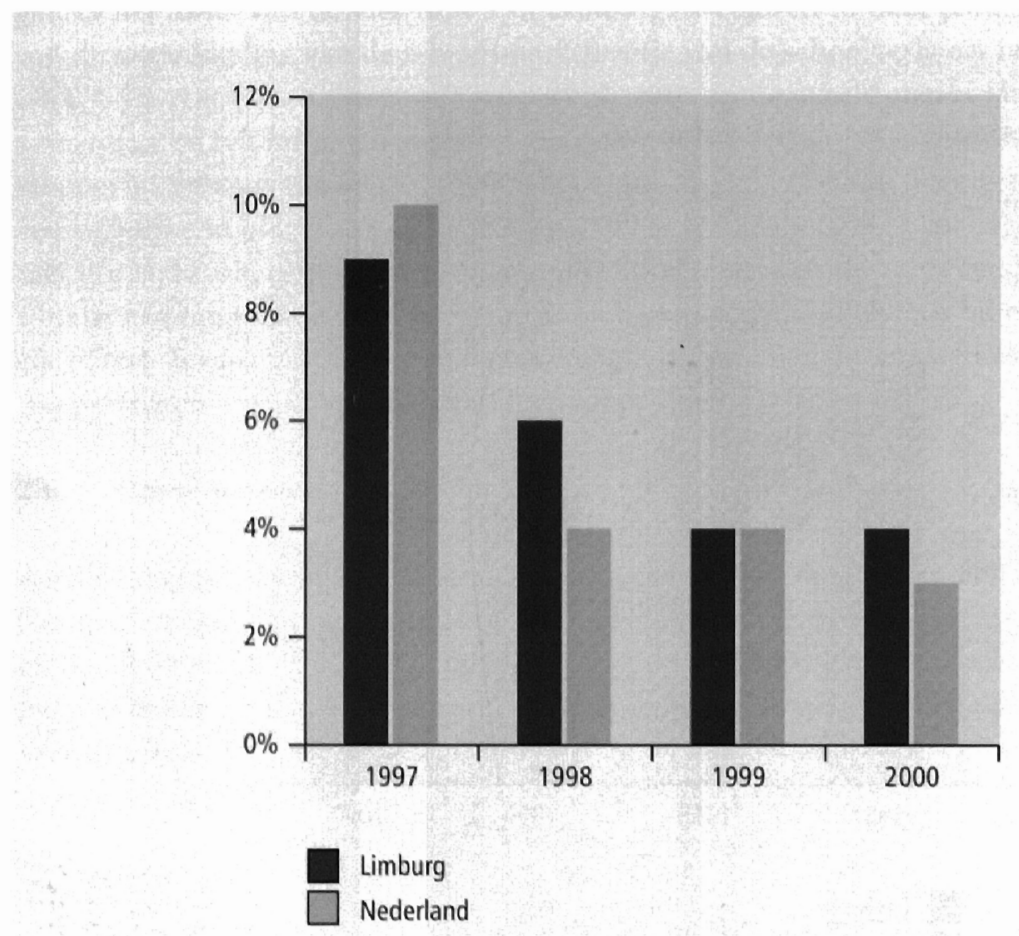

Brom: ROA 


\section{Beloning}

Een derde aspect dat een belangrijke rol speelt bij de inschatting van de arbeidsmarktpositie van schoolverlaters is het brutoloon dat zij gemiddeld verdienen. Figuur 2.3 illustreert de ontwikkeling van het gemiddelde brutoloon van de schoolverlaters van het MBO in de afgelopen jaren. Na een sterke toename van het gemiddelde bruto maandloon in de periode 1997-1999, is in 2000 voor het eerst sinds 1996 het gemiddelde bruto maandloon van schoolverlaters in Limburg afgenomen. Deze omslag in de ontwikkeling van de Limburgse lonen zorgt er eveneens voor dat voor het eerst in de beschouwde periode het maandloon van de schoolverlaters in Limburg niet langer op een hoger niveau ligt dan het gemiddelde loon in Nederland.

Landelijk is het gemiddelde bruto maandloon ook weer verder gestegen. Tussen 1999 en 2000 is de stijging weliswaar bescheiden vergeleken met de voorgaande jaren, maar toch gaat de loonstijging in Nederland onverminderd door. De totale stijging van het loon tussen 1997 en 2000 bedraagt liefst 39\%. Het is opmerkelijk dat de landelijke loonstijging geheel voor rekening komt van de sector MBO Dienstverlening en gezondheidszorg ( $+8 \%)$. De lonen van de $\mathrm{MBO}$-schoolverlaters van de andere opleidingssectoren zijn in Nederland tussen 1999 en 2000 constant gebleven. Daarentegen is het gemiddelde brutoloon voor de schoolverlaters van MBO Dienstverlening en gezondheidszorg in Limburg in 2000 gedaald van 3.250 gulden ( 1.475 euro) naar 3.025 gulden ( 1.375 euro).

\section{Figuur 2.3}

Gemiddeld bruto maandloon (in guldens) onder MBO-schoolverlaters, Limburg en Nederland, 1997-2000

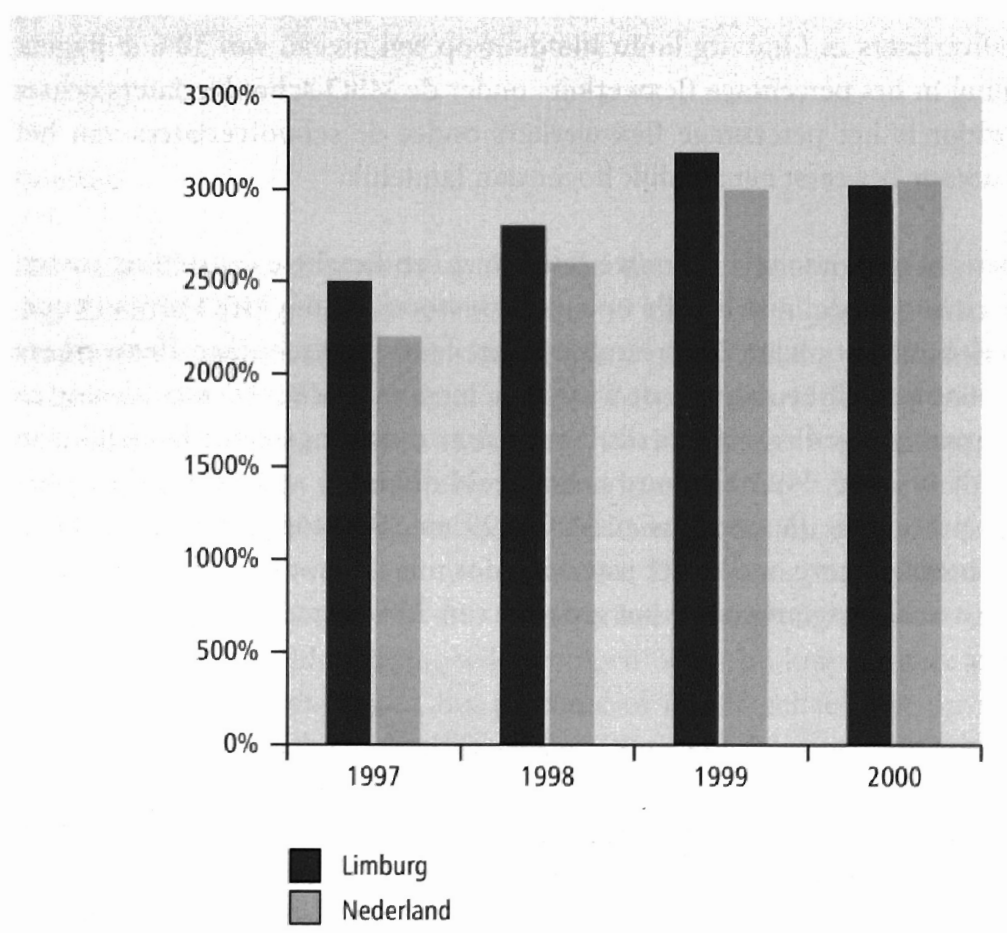

Bron: ROA 
Al met al kan worden geconcludeerd dat de Limburgse arbeidsmarkt voor MBO-schoolverlaters steeds meer overeenstemt met het landelijke beeld. De (intrede)werkloosheidspercentages zijn net als voorgaande jaren vergelijkbaar, en voor het eerst sinds 1996 ligt ook het gemiddelde bruto maandloon in Limburg op hetzelfde niveau als in Nederland.

\subsubsection{Verborgen discrepanties}

Naast de open discrepanties kan er ook sprake zijn van verborgen discrepanties bij degenen die wel werk hebben gevonden. Van dergelijke aansluitingsproblemen is bijvoorbeeld sprake als schoolverlaters werk moeten accepteren beneden hun niveau of buiten hun vakgebied, vaker een tijdelijke in plaats van een vaste aanstelling krijgen, of vaker genoegen moeten nemen met deeltijdwerk, terwijl men liever een fulltime betrekking zou willen hebben.

\section{Flexibele aanstelling}

Door de gunstige arbeidsmarktontwikkelingen in Limburg in de tweede helft van de jaren negentig zijn de verborgen discrepanties voor de schoolverlaters sterk verminderd. Figuur 2.4 illustreert dit met betrekking tot de aard van de aanstelling. De figuur schetst de ontwikkeling van het aantal schoolverlaters van het MBO dat een flexibele aanstelling heeft, dat wil zeggen: een contract als uitzendkracht, oproepkracht, invalkracht of tijdelijk contract. $\mathrm{Na}$ de sterke daling in het percentage $\mathrm{MBO}$-schoolverlaters met een flexibele aanstelling in de jaren daarvoor, is in Limburg tussen 1999 en 2000 een lichte toename van het percentage schoolverlaters met een flexibele aanstelling waar te nemen. Het percentage flexwerkers onder de schoolverlaters in Limburg komt hierdoor op een niveau van $30 \%$ te liggen. Landelijk zet de daling in het percentage flexwerkers onder de MBO-schoolverlaters echter nog wel door. Hierdoor is het percentage flex-werkers onder de schoolverlaters van het $\mathrm{MBO}$ in Limburg nu voor het eerst aanzienlijk hoger dan landelijk.

De afname in het percentage werkende schoolverlaters met een flexibele aanstelling tussen 1999 en 2000 heeft zich in Nederland bij alle opleidingssectoren op het MBO-niveau voorgedaan. MBO Techniek heeft ook in 2000 landelijk het laagste percentage flexwerkers (16\%), maar de grootste landelijke daling valt waar te nemen voor MBO Dienstverlening en gezondheidszorg. Het percentage flexwerkers daalt voor deze opleidingssector landelijk van $29 \%$ in 1999 naar 23\% in 2000. Voor Limburg is het beeld duidelijk anders. Bij alle opleidingsectoren is het percentage flexwerkers tussen 1999 en 2000 toegenomen. Bij MBO Dienstverlening en gezondheidszorg, welke het jaar daarvoor nog de grootste daling liet zien, is de stijging van het aantal flexwerkers nu het grootst (van $25 \%$ naar $29 \%$ ). 
Figuur 2.4

Percentage MBO-schoolverlaters met een flexibele aanstelling, Limburg en Nederland, 19972000

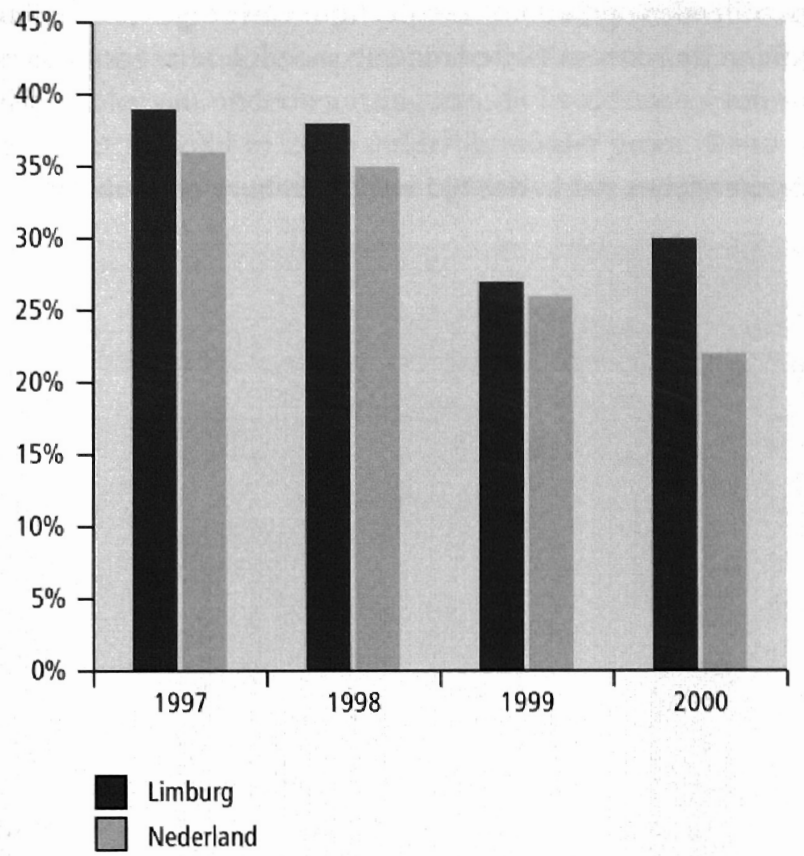

Bron: $R O A$

\section{Deeltijd}

Het verband tussen de situatie op de arbeidsmarkt en het werken in deeltijd is niel cenduidig. Enerzijds geven werkgevers er in een situatie van hoogconjunctuur en arbeidsmarktkrapte de voorkeur aan dat mensen voltijds werken. Zolang werknemers ook graag volıijds willen werken, zal er een positief verband bestaan tussen de conjuncturele situatie en het percentage werknemers dat voltijds werkt. Anderzijds geeft een gunstige economische situatie werknemers een zekere mate van marktmachı. Voor zover er bij hen een voorkeur bestaat voor het werken in decltijd, is de kans groter dat zij deze eis ingewilligd krijgen wanneer er sprake is van personeelsschaarste. Dit zou met name kunnen gelden voor vrouwen met jonge kinderen, of van schoolverlaters die graag nog wat meer vrije tijd willen hebben of een deeltijdopleiding willen volgen. Waar bij krapte op de arbeidsmarkt werkgevers de keuze hebben tussen het parttime of in het geheel niet opvullen van een openstaande vacature, zullen ook zij in veel gevallen aan de eerste optie de voorkeur geven.

Figuur 2.5 schetst de ontwikkeling in het percentage MBO-schoolverlaters dat in deelrijd werkı. Landelijk neemt het percentage MBO-schoolverlaters dat in decltijd werkzaam is nog altijd toe. De stijging in het percentage is gering maar gestaag en het percentage schoolverlaters dat in deeltijd werkzaam is komt voor 2000 uit op $28 \%$. Het verloop in Limburg 
is grilliger en lijkt minder één bepaalde kant op te wijzen. De sterke stijging tussen 1997 en 1998 werd gevolgd door een daling tussen 1998 en 1999, en in 2000 staat het percentage onveranderd op $24 \%$. Wanneer de onverminderde landelijke toename in het percentage deeltijders doorzet, zal de thans nog geringe kloof tussen Limburg en Nederland allengs groter worden. In hoeverre dit valt toe te schrijven aan verschillen in conjuncturele ontwikkelingen of aan verschillende voorkeuren voor deeltijd- en voltijdwerk tussen de Limburgse schoolverlaters en die in de rest van Nederland valt moeilijk te zeggen.

\section{Figuur 2.5}

Percentage MBO-schoolverlaters dat in deeltijd werkt, Limburg en Nederland, 1997-2000

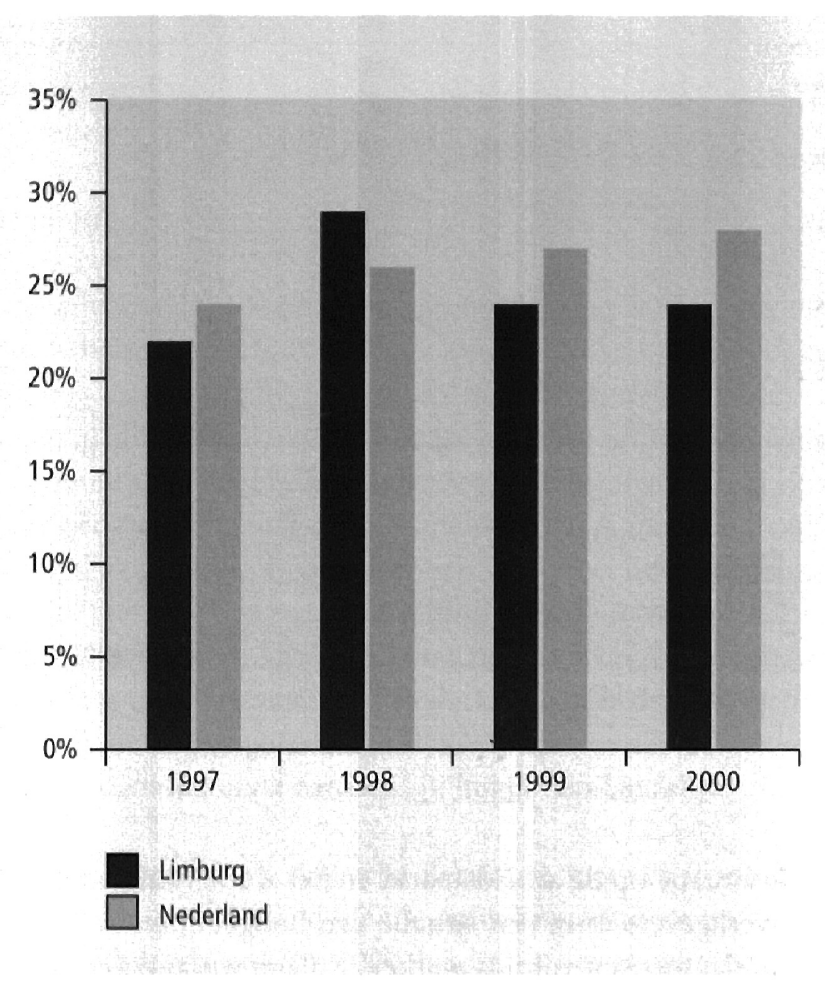

Bron: ROA

Ook in 2000 zijn de verschillen in het percentage schoolverlaters dat in deeltijd werkt tussen de vier opleidingssectoren aanzienlijk. Zo werkt in Limburg in 2000 van de schoolverlaters van MBO Techniek slechts 4\% in deeltijd. In 1999 bedroeg dit percentage nog 7\%. Voor MBO Dicustverlening en gezondheidszorg daarentegen bedraagt het percentage deeltijders maar liefst 53\%. De sector MBO Economie neemt zowel in Limburg als landelijk een tusscupositic in. Het percentage deeltijders bij de verschillende opleidingssectoren is in Limburg in 2000 redelijk goed vergelijkbaar met de landelijke percentages, met uitzondering van MBO Tichnick welke landelijk een twee maal zo groot percentage deeltijders heeft $(8 \%)$ als in Limburg. 


\section{Onderbenutting}

Aansluitingsproblemen op de arbeidsmarkt voor schoolverlaters manifesteren zich ook vaak in de noodzaak voor schoolverlaters om een baan onder hun niveau te accepteren. Men spreekt dan wel van een onderbenutting van iemands kwalificaties. Figuur 2.6 laat zien dat ook deze onderbenutting de laatste jaren geen eenduidig verloop kent. We zien zelfs een tegengesteld beeld voor Limburg ten opzichte van Nederland. In Limburg is er vanaf 1998 veel minder vaak sprake van onderbenutting van de kwalificaties van schoolverlaters dan landelijk, al wordt het verschil in 2000 duidelijk minder groot. Rond $30 \%$ van de MBOschoolverlaters in Limburg zegt onderbenut te worden, tegenover ongeveer $35 \%$ in Nederland.

Figuur 2.6

Onderbenutting voor MBO-schoolverlaters, Limburg en Nederland, 1997-2000

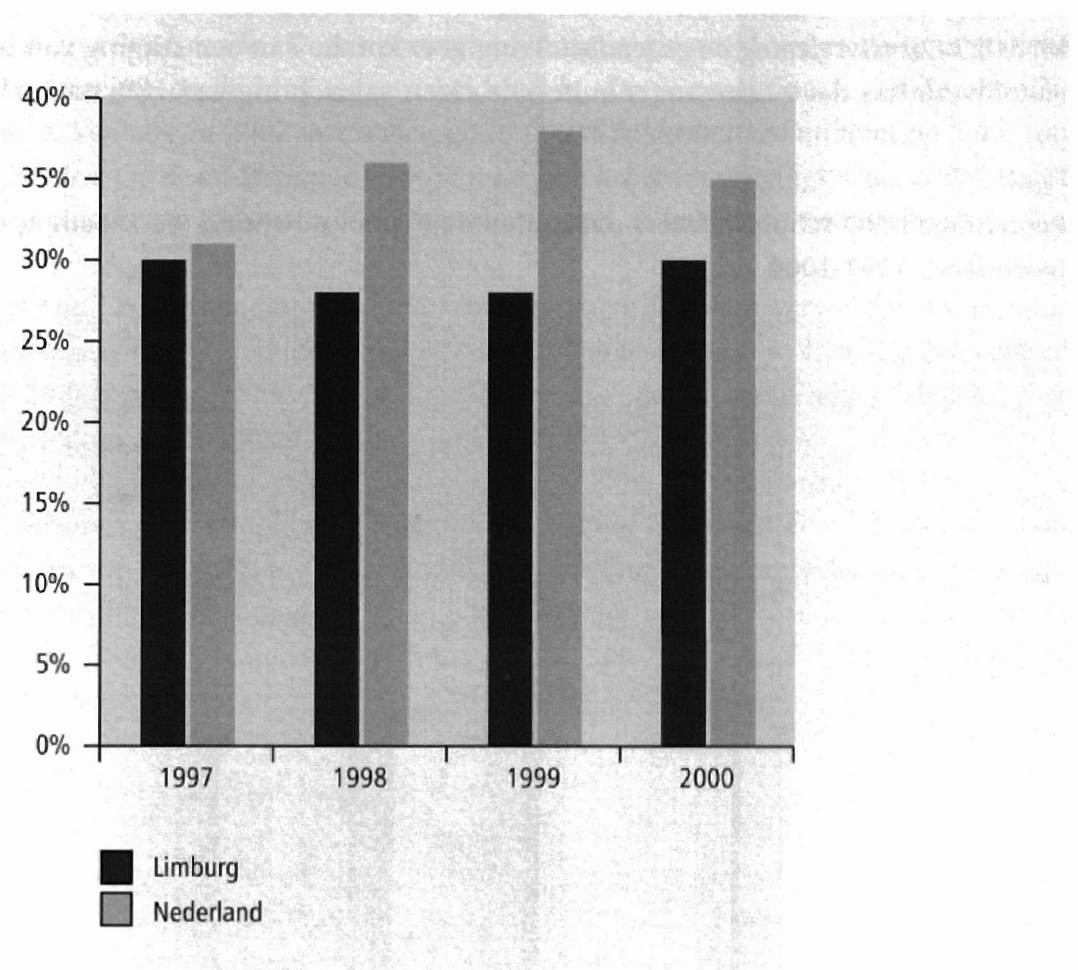

Bron: ROA

De onderbenutting van de schoolverlaters van MBO Techniek vertoont zowel landelijk als in Limburg een golfpatroon. Daalde het percentage in Nederland van $46 \%$ in 1998 naar 38\% in 1999, nu stijgt het percentage weer naar 44\%. In Limburg is het patroon precies omgekeerd. Tussen 1998 en 1999 was er sprake van een toename van de onderbenuting, die nu word gevolgd door een daling (van 36\% naar 32\%). Ook voor MBO Dienstverlening en gezondheidszorg zijn de ontwikkelingen op dit punt in Limburg en Nederland tegengesteld: in Limburg stijgt het percentage onderbenutting voor schoolverlaters van deze opleidingssector waarvan de kwalificaties worden onderbenut van $27 \%$ naar $37 \%$, terwijl er landelijk 
juist een daling van $36 \%$ naar $27 \%$ valt waar te nemen. Hierdoor is MBO Dienstverlening en gezondheidszorg de enige opleidingssector die in Limburg een grotere mate van onderbenutting vertoont dan landelijk.

\section{Buiten vakrichting}

Een laatste aspect van de verborgen aansluitingsproblematiek op de arbeidsmarkt is het percentage schoolverlaters dat buiten de eigen vakrichting werkzaam is. Figuur 2.7 laat zien dat dit percentage vrij stabiel is (met uitzondering van het hoge landelijke percentage in 1998). Rond 30\% van de MBO-schoolverlaters in Limburg en Nederland werkt buiten de eigen vakrichting.

Hoewel de percentages zowel landelijk als in Limburg stabiel zijn voor het MBO als geheel, geldt dit allerminst voor de percentages van de verschillende opleidingssectoren. In Limburg zijn MBO Economie en MBO Techniek weliswaar redelijk constant gebleven, maar bij MBO Dienstverlening en gezondheidszorg is er sprake van een stijging van het percentage schoolverlaters dat werkzaam is buiten de eigen vakrichting van $18 \%$ naar $41 \%$.

Figuur 2.7

Percentage MBO-schoolverlaters dat buiten de eigen vakrichting werkzaam is, Limburg en Nederland, 1997-2000

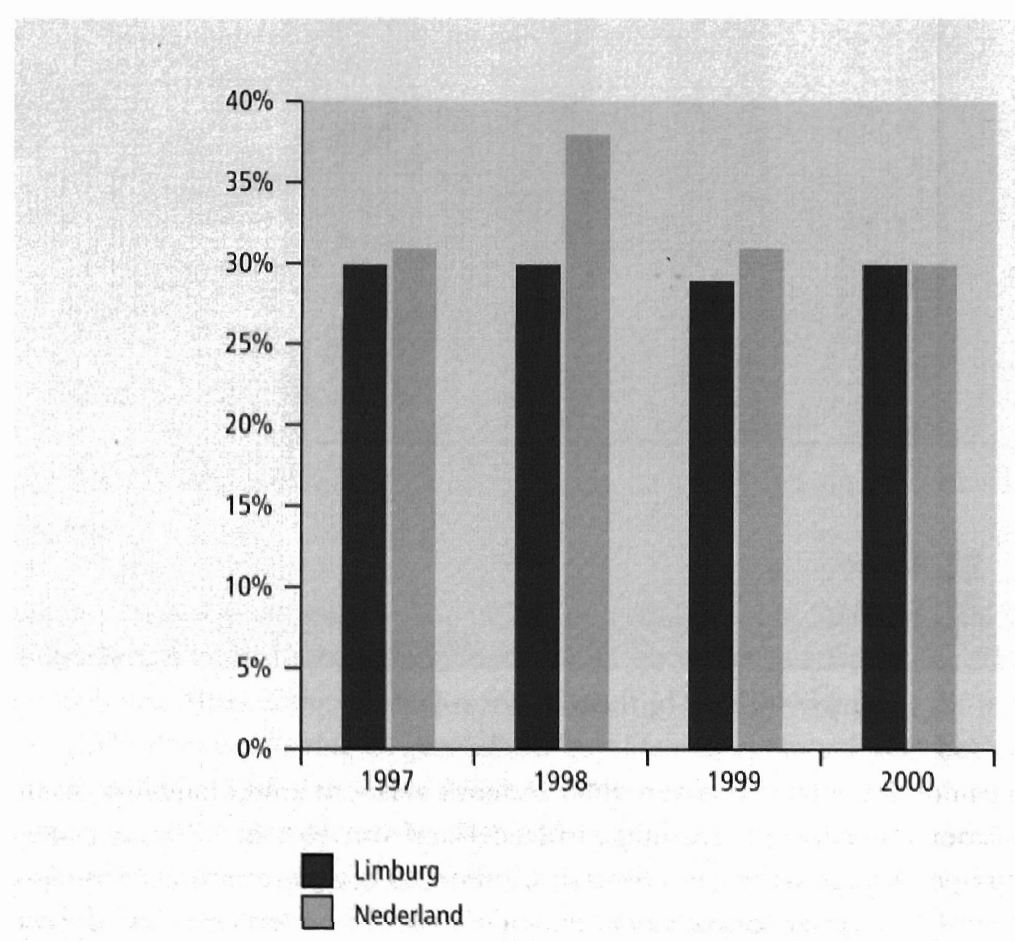

Bron: ROA 


\section{De Limburgse arbeidsmarkt op de korte en de middellange termijn}

De economische groei zal in Limburg naar verwachting in 2002 op een lager niveau liggen dan in de voorgaande jaren. De werkgelegenheid zal toenemen met ongeveer 1\%. Deze groei is goed voor ongeveer 5.000 banen. Dit is een daling ten opzichte van de in het vorige RAlL-rapport verwachte groei van $2 \%$ voor het jaar 2001 . De verwachte groei voor de Limburgse arbeidsmarkt op de middellange termijn (tot 2006) komt met ongeveer 20.000 banen uit op 0,8\% gemiddeld per jaar. Dit betekent dat de Limburgse werkgelegenheidsgroei de komende jaren achterblijf bij de landelijke groeiprognose.

Naast de uitbreidingsvraag, die een indicatie geeft van de groei van de werkgelegenheid, genereert ook de vervangingsvraag als gevolg van (vervroegde) pensionering, arbeidsongeschiktheid, tijdelijke terugtreding van de arbeidsmarkt, beroepsmobiliteit en dergelijke, een vraag naar nieuwkomers op de arbeidsmarkt. Deze vervangingsvraag is als altijd veruit de belangrijkste component van de vraag op de Limburgse arbeidsmarkt. De verwachting is dat de arbeidsmarktuitstroom in Limburg in 2002 met ongeveer 20.000 arbeidsplaatsen uitkomt op 5,4\% van het aantal werkenden. Op de middellange termijn is de verwachte vervangingsvraag circa $4 \%$ per jaar. Deze vervangingsvraag ligt op een iets hoger niveau dan de landelijke vervangingsbehoefte.

De uitbreidingsvraag en vervangingsvraag vormen tezamen de totale verwachte vraag naar nieuwkomers op de Limburgse arbeidsmarkt. Het aantal baanopeningen in Limburg bedraagt in 2002 ongeveer 26.000 arbeidsplaatsen; 5,4\% van het huidige aantal werkenden. Het jaarlijkse aantal baanopeningen op de middellange termijn ligt op hetzelfde niveau.

Tegenover deze baanopeningen staat het verwachte aanbod van nieuwkomers. De arbeidsmarktinstroom van schoolverlaters blijft in Limburg in 2002 vergelijkbaar met de prognoses voor 2001. Er zal, naar verwachting, een aanbod van nieuwe schoolverlaters op de Limburgse arbeidsmarkt zijn ter grootte van 4,8\% van het aantal werkenden. Dit aanbod van schoolverlaters blijft achter bij de vraag naar nieuwkomers; om precies te zijn met 0,6\% van het totaal aantal werkenden.

\subsection{Inleiding}

In dit hoofdstuk zal worden ingegaan op de prognoses van de ontwikkelingen op de Limburgse arbeidsmarkt op de korte en de middellange termijn. In paragraal 3.2 presenteren we allereerst de prognoses van de uitbreidingsvraag. Deze geven een indicatie van de gevolgen van de economische groeiverwachtingen voor de werkgelegenheidsontwikkelingen in Limburg en de mede daaraan gerelateerde verschuivingen in de sectorale werkgelegenheidsstructuur. Daarna volgen in paragraal 3.3 de prognoses van de vervangingsvraag. In tegenstelling tot het vorige RAIL-rapport spitsen we de vraag-aanbodvergelijking in dit rapport geheel toe op de schoolverlaters. Daarom beperken we ons bij het bespreken van de vervangingsvraag tot de vervangingsvraag naar schoolverlaters, de zogenaamde nelto vervangingsvraag".

15 Wanneer we naast de schoolverlaters ook de baanwisselaars en de herintreders als aanbodgropen zouden onderscheiden, dan zouden we moeten uigaan van de bruto vervangingsvraag. Deze kan namelijk worden gezien als de totale vervangingsvraag naar zowel schoolverlaters als baanwisselaars en herintreders. 
De uitbreidingsvraag en de vervangingsvraag geven tezamen de totale verwachte vraag naar nieuwe arbeidskrachten op de Limburgse arbeidsmarkt. Deze prognoses van de totale vraag presenteren we in paragraaf 3.4. In paragraal 3.5 worden hier de verwachte aanbodprognoses van schoolverlaters tegenover gezet. De arbeidsmarktperspectieven voor nieuwkomers op de arbeidsmarkt en de knelpunten in de personeelsvoorziening die volgen uit de verwachte vraag- en aanbodontwikkelingen, worden in hoofdstuk 4 gepresenteerd.

\subsection{Uitbreidingsvraag}

De prognoses van de middellange termijn uitbreidingsvraag zijn gebaseerd op de werkgelegenheidsprognoses voor bedrijfssectoren van het Centraal Planbureau (CPB). Hierbij is uitgegaan van het zogenaamde 'Global Competition Scenario' in een lange termijnverkenning van het $\mathrm{CPB}^{16}$. In afwijking van dit lange termijnscenario is voor de prognoses van de uitbreidingsvraag voor 2002 gebruik gemaakt van het Centraal Economisch Plan 2001 (CEP) van het $\mathrm{CPB}^{17}$. Door het gebruik van deze korte termijnprognoses wordt het gehanteerde lange termijnscenario gecorrigeerd met de meer recente inzichten in de groeiverwachtingen van het CEP. Daarnaast is voor de regionale verbijzondering van bovenstaande prognoses gebruik gemaakt van regionale arbeidsmarktprognoses ${ }^{18}$ zoals deze voor Arbeidsvoorziening zijn gemaakt door TNO/Inro/SEOR.

\section{Bedrijfssectoren}

Tabel 3.1' geeft voor de verschillende sectoren de uitbreidingsvraag op de korte en middellange termijn weer als percentage van de werkgelegenheid bij aanvang van de prognoseperiode. Deze cijfers worden voor de middellange termijn ook vergeleken met het landelijke beeld ${ }^{19}$. De tabel laat zien dat de werkgelegenheidsgroeiverwachting voor 2002 minder gunstig uitpakt dan de eerdere prognoses voor 2001. Toen was er slechts één bedrijfssector - Landbouw en visserij - waarvoor in Limburg een krimpende werkgelegenheid werd verwacht. Nu wordt er voor drie bedrijfssectoren een krimpende werkgelegenheid voorspeld: Landbouw en visserij, Chemie en Metaal en elektrotechniek. Met uitzondering van de sector Energie wordt voor de andere bedrijfssectoren voor 2002 werkgelegenheidsgroei verwacht. Met name voor de bedrijfssectoren Handel, Transport en communicatie, Horeca, reparatic en zakelijke dienstverlening en Kwartaire diensten wordt een relatief hoge groei verwacht van $2,4 \%$ of meer.

Wanneer we kijken naar de verwachting op de middellange termijn dan valt op dat voor een aantal bedrijfssectoren een omslag in de werkgelegenheidsontwikkeling wordt voorspeld. Verwacht wordt dat Chemie zich op de middellange termijn herstelt van de werkgelegenheidskrimp in 2002. Omgekeerd geldt dat in de sector Overige industrie de groei op de korte termijn naar verwachting omslaat in een daling op middellange termijn. Opmerkelijk is ook de omslag voor de sector Bank en verzekeringswezen. Voor deze bedrijfssector wordt

\footnotetext{
16 Zie: Omgevingssconarios Lange Termijn Verkenning 1995-2020, Werkdocument No. 89. Centraal Planbureau, Den Haag, 1907

17 Zic: Centraal Economisch Plan 2001, Centraal Planbureau, Den Haag, 2001.

18 Zie: Regionali arbeidsmarktprognoses 2001-2006. Arbeidsvoorziening, 2001.

19) Zie: De arbeidsmarlit naar opleiding en beroep tor 2006, ROA-R-2001/8, Maastricht, 2001
} 
na een jarenlange groei op de middellange termijn een krimpende werkgelegenheid verwacht.

De totale verwachte middellange termijn werkgelegenheidsgroei is voor Limburg sowieso lager dan voor Nederland als geheel wordt verwacht. Een reden hiervoor is dat Limburg relatief meer werk biedt in conjunctuurgevoelige sectoren. Het grotere gewicht van deze sectoren - die eerder en heviger de gevolgen zullen voelen van een economische teruggang - remı de verwachte werkgelegenheidsgroei in Limburg.

Tabel 3.1

Verwachte uitbreidingsvraag (als percentage van de werkgelegenheid) naar bedrijfssector in 2002 en in de periode 2001-2006, Limburg en Nederland

\begin{tabular}{lrrr} 
& Limburg & Limburg & Nederland \\
Bedrijssector & 2002 & $2001-2006$ & $2001-2006$ \\
& $\%$ & $\%$ & $\%$ \\
\hline Landbouw en visserij & $-2,6$ & -10 & -10 \\
Voeding & 0,1 & 4 & 4 \\
Chemie & $-0,2$ & 4 & 4 \\
Metaal en elektrotechniek & $-0,2$ & -1 & -1 \\
Overige industrie & 0,1 & -4 & -4 \\
Energie & $-0,0$ & 2 & 2 \\
Bouw en onroerend goed & 0,9 & 6 & 9 \\
Handel & 2,8 & 8 & 8 \\
Transport en communicatie & 2,5 & 4 & 5 \\
Bank en verzekeringswezen & 2,3 & -2 & -2 \\
Horeca, reparatie en zakelijke dienstverlening & 2,0 & 11 & 7 \\
Kwartaire diensten & 2,4 & 5 & 5 \\
Overheid en onderwijs & 1,5 & 4 & 6 \\
Totaal & & & 7
\end{tabular}

Bron: Arbeidsvoorziening/CBS/CPB/ROA

\section{Beroepsklassen}

Hoe vertalen de groeiverwachtingen van de verschillende bedrijfssectoren zich naar werkgelegenheidsverwachtingen voor de beroepsklassen? Tabel 3.2 geeft een overzicht van de verwachte uitbreidingsvraag op de korte en middellange termijn per beroepsklasse in Limburg. Zoals reeds eerder is aangegeven, is er voor de diverse beroepsgroepen meer gedetailleerde informatie te vinden in de Statistische Bijlage van dit rapport. Op de korte termijn wordt er een relatief sterke groei van de werkgelegenheid verwacht voor de Informaticaberoepen, Sociaal-culturele beroepen en de Medische en paramedische beroepen. 
Daarentegen wordt er een lage groei, of zelfs een krimpende werkgelegenheid verwacht voor de conjunctuurgevoelige Agrarische beroepen, Technische en industrieberoepen en Openbare orde- en veiligheidsberoepen. ${ }^{20}$

Dezelfde beroepsklassen yormen ook op de middellange termijn de uitschieters in Limburg Bij de Agrarische beroepen en de Technische en industrieberoepen slaat de lage groeiverwachting voor de korte termijn zelfs om in een daling van de werkgelegenheid op de middellange termijn. Vergeleken met Nederland als geheel geldt dat er geen uniform beeld waarneembaar is. Sommige beroepsklassen geven in Limburg een hogere uitbreidingsvraag te zien dan landelijk, maar andere beroepsklassen juist een lagere groei. Dit laatste is het geval bij de Pedagogische beroepen (-1\% in Limburg t.o.v. 4\% landelijk), Technische en industrieberoepen ( $-4 \%$ t.o.v. $0 \%$ ) en Openbare orde- en veiligheidsberoepen ( $-8 \%$ t.o.v. $3 \%$ ).

Tabel 3.2

Verwachte uitbreidingsvraag (als percentage van de werkgelegenheid) naar beroepsklasse in 2002 en in de periode 2001-2006, Limburg en Nederland

\begin{tabular}{lrrr} 
Beroepsklasse & Limburg & Limburg & Nederland \\
& 2002 & $2001-2006$ & $\%$ \\
& $\%$ & $\%$ & 4 \\
\hline Pedagogische beroepen & 0,9 & -1 & 8 \\
Culturele beroepen & 0,6 & -4 & -7 \\
Agrarische beroepen & 0,1 & -4 & 0 \\
Technische en industrieberoepen & 0,4 & 1 & 3 \\
Transportberoepen & 0,7 & 11 & 4 \\
Medische en paramedische beroepen & 2,8 & 9 & 11 \\
Economisch-administratieve beroepen & 1,5 & 16 & 15 \\
Informaticaberoepen & 4,1 & 19 & 17 \\
Sociaal-culturele beroepen & 2,4 & 2 & 3 \\
Verzorgende en dienstverlenende beroepen & 1,1 & -8 & 3 \\
Openbare orde- en veiligheidsberoepen & $-1,6$ & 4 & 5
\end{tabular}

Bron: Arbeidsvoorziening/CBS/CPB/ROA

In het volgende omkaderde schema wordt een overzicht gegeven van de prognoses voor de meer specifieke beroepsgroepen, waarvoor de verwachte korte of middellange termijn uitbreidingsvraag in Limburg relatief hoog of laag zal zijn ${ }^{21}$. Opmerkelijk is dat het beeld

20 Ten aanzien van de Openbare orde- $e$ veiligheidsberoepen moet de kanttekening worden gemaakt dat bij de prognoses geen rekening is gehouden met de mogelijke gevolgen voor de werkgelegenheid in deze berocpen van de sinds de aanslagen in de Verenigde Staten sterk toegenomen aandacht voor beveiliging en bewaking. Het is op dit punt overigens de vraag of dit ook een positief effect zal hebben op de werkgelegenheidsontwikkeling in deze beroepen in Limburg.

21 In deze overzichtsschema's worden alleen de beroepen of opleidingen genoemd waarvoor in de Staristische Bijlage daadwerkelijk een percentage wordt vermeld, dat wil zeggen de beroepen en opleidingen met minimaal 2.500 werkenden in Limburg. 
van de groei- en krimpberoepen op de korte termijn sterk verschilt van het beeld op de middellange termijn. Een uitzondering vormen aan de ene kant de productieplanners, waarvoor zowel op de korte termijn als de middellange termijn een hoge uitbreidingsvraag wordt verwacht, en aan de andere kant de bouwvakkers en de weg-en waterbouwkundig arbeiders, waarvoor zowel op de korte als de middellange termmijn een krimpende werkgelegenheid wordt verwacht. De groeiberoepen op de middellange termijn zijn met name de hogere beroepen, met uitzondering van de ziekenverzorgenden.

\section{KORTE TERMIJN:}

Beroepsgroepen met een relatief hoge uitbreidingsvraag in Limburg:

- Confectie-arbeiders

- Juridisch en fiscaal medewerkers

- Weg- en waterbouwkundige vakkrachten

- Elektromonteurs

- Productieplanners

- Winkeliers

Beroepsgroepen met een relatief lage uitbreidingsvraag in Limburg:

- Bibliotheekassistenten

- Monteurs

- Weg- en waterbouwkundige arbeiders

- Kunstenaars

- Werktuigbouwkundig ontwerpers en hoofden technische dienst

- Bouwvakkers

\section{MIDDELLANGE TERMIJN:}

Beroepsgroepen met een relatief hoge uitbreidingsvraag in Limburg:

- Accountants

- Productieplanners

- Activiteitenbegeleiders en medewerkers arbeidsbemiddeling

- Ziekenverzorgenden

- Organisatie-adviseurs

- Managers

Beroepsgroepen met een relatief lage uitbreidingsvraag in Limburg:

- Weg- en waterbouwkundig arbeiders

- Receptionisten en administratieve employees

- Docenten talen en expressie

- Politieagenten, onderofficieren en beveiligingsemployés

- Mechanisch operators

- Bouwvakkers 


\section{Opleidingssectoren}

In tabel 3.3 wordt een overzicht gegeven van de verwachte korte en middellange uitbreidingsvraag per opleidingssector. De in de tabel weergegeven prognoses duiden eens te meer op de grote verschillen tussen de arbeidsmarktontwikkelingen voor de lager en hoger opgeleiden. Evenals in het vorige RAIL-rapport kan men ruwweg stellen dat degenen met alleen Basisonderwijs of een VMBO-opleiding worden geconfronteerd met een sterk afnemende vraag, terwijl de verwachte groei voor de opleidingen op $\mathrm{HBO}$ - en WO-niveau juist (erg) groot is. De middengroep met een opleidingsachtergrond op $\mathrm{MBO}$-niveau heeft zowel op korte als middellange termijn een gemiddelde uitbreidingsvraag.

\section{Tabel 3.3}

Verwachte uitbreidingsvraag (als percentage van de werkgelegenheid) naar opleidingssector in 2002 en in de periode 2001-2006, Limburg en Nederland

\begin{tabular}{|c|c|c|c|}
\hline Opleidingssector & $\begin{array}{r}\text { Limburg } \\
2002\end{array}$ & $\begin{array}{r}\text { Limburg } \\
2001-2006\end{array}$ & $\begin{array}{l}\text { Nederland } \\
2001-2006\end{array}$ \\
\hline & $\%$ & $\%$ & \\
\hline Basisonderwijs & 0,3 & -23 & -23 \\
\hline VMBO Theorie & 0,0 & -2 & 1 \\
\hline VMBO Landbouw en natuurlijke omgeving & 0,3 & -32 & -12 * \\
\hline VMBO Techniek & 0,2 & -14 & $-12^{*}$ \\
\hline VMBO Economie & 0,0 & -17 & -6 \\
\hline VMBO Verzorging & $-0,3$ & -10 & -8 \\
\hline HAVO/VWO & 1,0 & 14 & 16 \\
\hline MBO Landbouw en natuurlijke omgeving & 0,4 & 15 & $10^{*}$ \\
\hline MBO Techniek & 0,9 & 6 & $10^{*}$ \\
\hline MBO Economie & 1,2 & 6 & 8 \\
\hline MBO Dienstverlening en gezondheidszorg & 1,6 & 8 & 7 \\
\hline HBO Landbouw & 1,3 & 13 & 11 * \\
\hline HBO Techniek & 2,6 & 9 & $11^{*}$ \\
\hline HBO Economie & 2,5 & 18 & 19 \\
\hline HBO Onderwijs en sociaal-cultureel & 0,9 & 6 & 9 \\
\hline HBO Paramedisch & 2,7 & 28 & 22 \\
\hline WO Landbouw en milieukunde & - & - & $14^{*}$ \\
\hline WO Techniek & 1,1 & 12 & $14^{*}$ \\
\hline WO Economie & 2,1 & 26 & 28 \\
\hline WO Letteren en sociaal-cultureel & 1,9 & 21 & 21 \\
\hline WO Medisch & 4,8 & 10 & 2 \\
\hline Totaal & 1,1 & 4 & 6 \\
\hline
\end{tabular}

* In De arbeidsmarkt naar opleiding en beroep tot 2006 zijn, op alle opleidingsniveaus, de opleidingsrichtingen 'Landbouw' en 'Techniek' samengevoegd tot 'Landbouw en techniek'.

Bron: Arbeidsworzicning/CBS/CPB/ROA 
De groeiverwachtingen op de korte termijn zijn het gunstigst voor de opleidingssectoren WO Medisch, HBO Paramedisch, WO Economie, HBO Economie en HBO Techniek. Veel uitbreidingsvraag met name dus voor hogere en wetenschappelijke opleidingen in de medische en economische richtingen. Daarentegen concentreert de stagnerende uitbreidingsvraag zich, als gezegd, bij de lagere opleidingen, zoals VMBO Economie en VMBO Verzorging. Het is dus ook duidelijk dat de vraag naar economisch en medisch opgeleiden sterk uiteenloopt tussen de verschillende opleidingsniveaus.

De verwachte uitbreidingsvraagpercentages voor Limburg op de middellange termijn geven een beeld te zien dat goed vergelijkbaar is met dat van de korte termijn: een hoge uitbreidingsvraag voor iemand met een $\mathrm{HBO}$ - of WO-opleiding, en een sterk krimpende werkgelegenheid voor mensen met alleen Basisonderwijs of een VMBO-opleiding. De opleidingssector HAVO/VWO geeft vanwege haar algemene karakter en de hieruit resulterende brede instroommogelijkheden, voor de middellange termijn een hoge uitbreidingsvraag te zien. Ze onttrekt zich hiermee ietwat van het algemene beeld van de lagere, meer voorbereidende, opleidingen. In het algemeen kan echter worden geconcludeerd dat voor mensen zonder een zogenaamde 'startkwalificatie' voor de arbeidsmarkt op MBO-niveau of hoger de werkgelegenheid in Limburg de komende jaren weer verder zal afbrokkelen.

Het beeld dat voor de middellange termijn uit tabel 3.3 naar voren komt, strookt in grote lijnen goed met het landelijke beeld. Er zijn eigenlijk vier uitzonderingen op deze regel. VMBO Economie en VMBO Theorie zijn twee opleidingssectoren waarvoor de werkgelegenheid in Limburg naar verwachting sterker krimpt dan landelijk. Omgekeerd geldt dat de opleidingssectoren HBO Paramedisch en WO Medisch juist een veel hogere groei vertonen in Limburg.

In het volgende omkaderde schema wordt, evenals voor de beroepen werd gedaan, een overzicht gegeven van de meer specifieke opleidingstypen, waarvoor de verwachte uitbreidingsvraag op de korte of middellange termijn in Limburg relatief hoog of laag zal zijn. Het algemene beeld, zoals dit werd geschetst in tabel 3.3, is ook hier duidelijk zichtbaar: hoge uitbreidingsvraag voor opleidingstypen op het HBO- en WO-niveau en een lage uitbreidingsvraag c.q. krimp voor mensen met alleen Basisonderwijs en VMBO-opleidingen. De enige opleidingstypen die zich hieraan onttrekken zijn de HBO lerarenopleiding talen, $H B O$ lerarenopleiding natuur en techniek en HBO lerarenopleiding basisonderwijs. Voor deze HBOopleidingen is de verwachte uitbreidingsvraag in Limburg laag als gevolg van de verwachte werkgelegenheidskrimp voor de Pedagogische beroepen. 


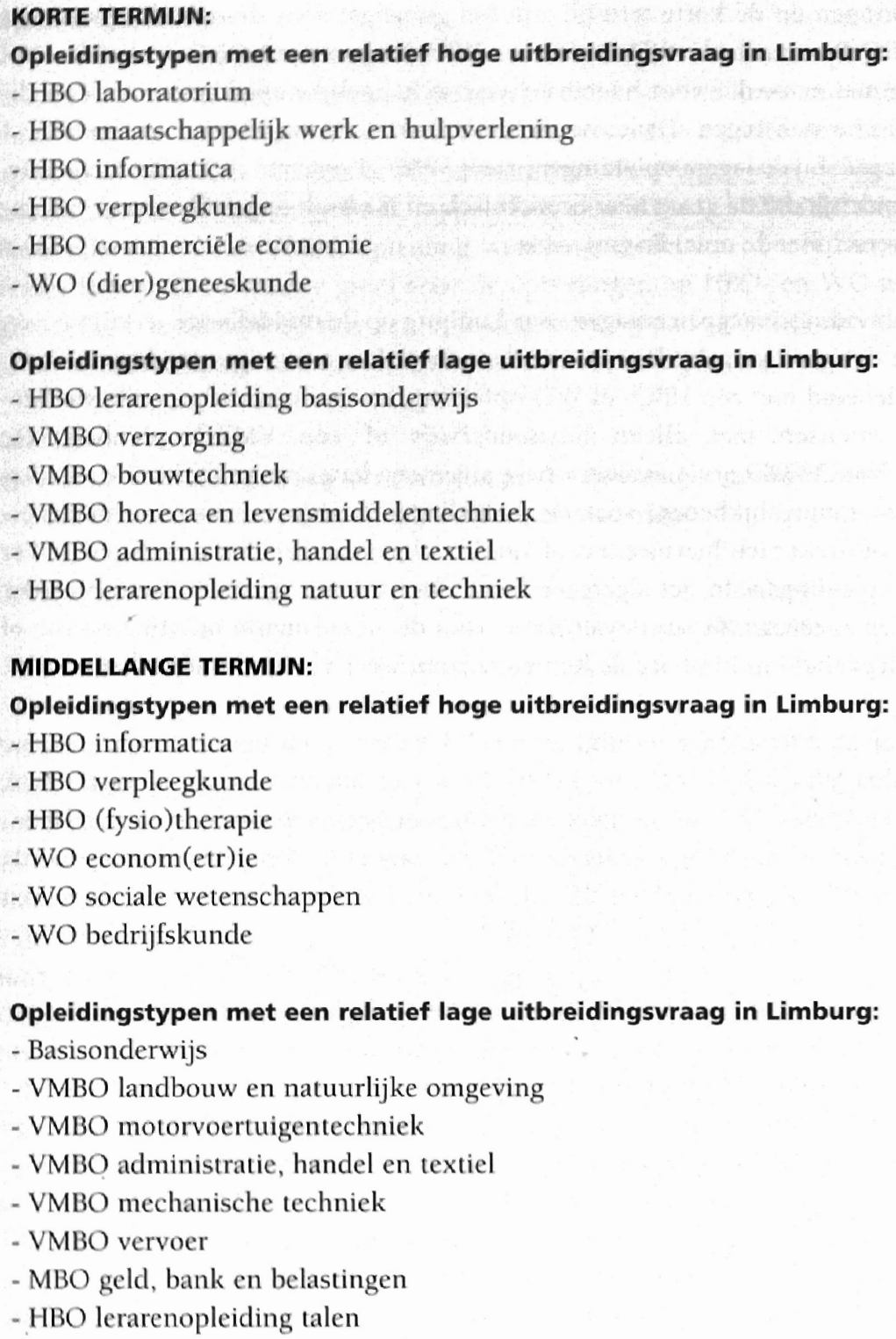

\subsection{Vervangingsvraag}

In deze paragraal behandelen we de tweede vraagcomponent: de vervangingsvraag. Zoals reeds cerder is angegeven, beperken we ons in dit rapport tot de netto vervangingsvraag, dat wil zeggen: de vervangingsvraag naar schoolverlaters

\section{Beroepsklassen}

Tabel $3 .+$ geef een overzicht van de in Limburg verwachte vervangingsvraag per beroepsklasse op de korte en de middellange termijn. Op de korte termijn is de vervangingsvraag 
naar beroep in Limburg gelijk aan ongeveer 22.000 arbeidsplaatsen. Dit aantal is equivalent met $4,8 \%$ van het aantal werkenden. Dit percentage is hoger dan de totale vervangingsvraag voor opleidingen. Dit is het gevolg van het feit dat de vervangingsvraag naar beroep ook rekening houdt met de beroepenmobiliteit, die geen invloed heeft op de vervangingsvraag naar opleiding ${ }^{22}$.

Tabel 3.4

Verwachte vervangingsvraag (als percentage van de werkgelegenheid) naar beroepsklasse in 2002 en in de periode 2001-2006, Limburg en Nederland

\begin{tabular}{lrrr} 
Beroepsklasse & Limburg & Limburg & Nederland \\
& 2002 & $2001-2006$ & $\%$ \\
& $\%$ & $\%$ & 21 \\
\hline Pedagogische beroepen & 5,4 & 24 & 16 \\
Culturele beroepen & 2,9 & 14 & 17 \\
Agrarische beroepen & 5,3 & 24 & 15 \\
Technische en industrieberoepen & 4,6 & 22 & 14 \\
Transportberoepen & 5,4 & 27 & 18 \\
Medische en paramedische beroepen & 5,4 & 24 & 16 \\
Economisch-administratieve beroepen & 4,5 & 21 & 9 \\
Informaticaberoepen & 2,7 & 14 & 13 \\
Sociaal-culturele beroepen & 3,8 & 18 & 15 \\
Verzorgende en dienstverlenende beroepen & 5,6 & 27 & 16 \\
Openbare orde- en veiligheidsberoepen & 4,8 & 23 & 16 *
\end{tabular}

* De percentages vervangingsvraag naar beroepsklasse in Limburg zijn niet goed te vergelijken met de landelijke cijfers, omdat in Limburg - vanwege de andere aanpak van de arbeidsaanbodprognoses per beroep - ook de doorleerders moeten worden meegenomen in de berekening van de vervangingsvraag van het beroepenmodel.

Bron: $R O A$

Beroepsklassen met een hoge verwachte vervangingsvraag zijn Verzorgende en dienstverlenende beroepen, Transportberoepen en Medische en paramedische beroepen. Daarentegen is de vervangingsvraag laag in de Informaticaberoepen en de Culturele beroepen, waarin relaticf veel jongeren werkzaam zijn. Deze beroepen zijn veel minder gevoelig voor de arbeids marktuittrede door pensioen, VUT, arbeidsongeschiktheid of zorgtaken. Ook in de Sociaal culturele beroepen is de vervangingsvraag relatief laag.

Het beeld van de korte termijn vertaalt zich naadloos naar de middellange termijn. Voor de Transportberoepen, Verzorgende en dienstverlenende beroepen, Pedagogische beroepen in

22 Daarentegen word de vervangingsvraag naar opleiding vergroot doordat werkenden door her volgen wall een hogere of andere postinitiele vervolgopleiding een andere opleidingsachtergrond krijgen on daardoes in feite een uitstroom van werkenden veroorzaken bij hun oorspronkelijke opleidingsachtergrond. 
Medische en paramedische beroepen wordt een hoge vervangingsvraag verwacht. Beroepsklassen met een op middellange termijn lage vervangingsvraag zijn weer de Informaticaberoepen. Culturele beroepen en Sociaal-culturele beroepen.

\section{KORTE TERMINN:}

Beroepsgroepen met een relatief hoge vervangingsvraag in Limburg:

- Docenten talen en expressie

- Bedrijfshoofden horeca

- Ziekenverzorgenden

- Confectie-arbeiders

- Metaalarbeiders

- Interieurverzorgers

Beroepsgroepen met een relatief lage vervangingsvraag in Limburg:

- Organisatiedeskundigen

- Organisatie-adviseurs

- Accountants

- Schoen- en kleermakers

- Systeemanalisten

- Juristen

MIDDELLANGE TERMIJN:

Beroepsgroepen met een relatief hoge vervangingsvraag in Limburg:

- Docenten talen en expressie

- Bedrijfshoofden horeca

- Ziekenverzorgenden

- Confectie-arbeiders

- Metaalarbeiders

- Interieurverzorgers

Beroepsgroepen met een relatief lage vervangingsvraag in Limburg:

- Organisatiedeskundigen

- Assistent-accountants

- Accountants

- Schoen- en kleermakers

- Systeemanalisten

- Juristen

In het voorgatande schema wordt een overzicht gegeven van de meer specifieke beroepsgroepen, waarvoor de verwachte vervangingsvraag in Limburg relatief hoog of relatief laag zal zijn. We zien geen verschil tussen de korte en de middellange termijn. De vervangingsvraag is met name relatief hoog voor een aantal verzorgende en dienstverlenende beroepen en relatief laag bij de meer economisch-administratieve beroepen. 


\section{Opleidingssectoren}

Tabel 3.5 geeft een overzicht van de verwachtingen van de vervangingsvraag per opleidingssector in Limburg op de korte en middellange termijn. Op korte termijn zien we de grootste vervangingsvraag bij de opleidingen Basisonderwijs, VMBO Theorie, VMBO Verzorging, MBO Dienstverlening en verzorging en $\mathrm{HBO}$ Onderwijs en sociaal-cultureel. Voor al deze opleidingssectoren is de vervangingsvraag meer dan $4,5 \%$. Met uitzondering van de opleidingen VMBO Economie of HBO Onderwijs en sociaal-cultureel, hebben lager opgeleiden op de korte termijn in het algemeen een hogere vervangingsvraag dan de hoger opgeleiden.

\section{Tabel 3.5}

Verwachte vervangingsvraag (als percentage van de werkgelegenheid) naar opleidingssector in 2002 en in de periode 2001-2006, Limburg en Nederland

\begin{tabular}{|c|c|c|c|}
\hline Opleidingssector & $\begin{array}{r}\text { Limburg } \\
2002\end{array}$ & $\begin{array}{r}\text { Limburg } \\
2001-2006\end{array}$ & $\begin{array}{l}\text { Nederland } \\
2001-2006\end{array}$ \\
\hline & $\%$ & $\%$ & $\%$ \\
\hline Basisonderwijs & 4,8 & 27 & 33 \\
\hline VMBO Theorie & 4,7 & 24 & 22 \\
\hline VMBO Landbouw en natuurlijke omgeving & 2,1 & 11 & 18 * \\
\hline VMBO Techniek & 4,8 & 24 & $18^{*}$ \\
\hline VMBO Economie & 2,7 & 13 & 19 \\
\hline VMBO Verzorging & 6,4 & 31 & 22 \\
\hline HAVO/NWO & 4,3 & 22 & 25 \\
\hline MBO Landbouw en natuurlijke omgeving & 3,0 & 14 & 19 * \\
\hline MBO Techniek & 3,9 & 19 & 19 * \\
\hline MBO Economie & 4,0 & 19 & 19 \\
\hline MBO Dienstverlening en gezondheidszorg & 4,9 & 24 & 19 \\
\hline HBO Landbouw & 1,8 & 8 & $16^{*}$ \\
\hline HBO Techniek & 3,3 & 16 & 16 * \\
\hline HBO Economie & 2,2 & 12 & 12 \\
\hline HBO Onderwijs en sociaal-cultureel & 4,8 & 23 & 21 \\
\hline HBO Paramedisch & 4,0 & 20 & 16 \\
\hline WO Landbouw en milieukunde & - & - & 12 * \\
\hline WO Techniek & 1,4 & 7 & 12 * \\
\hline WO Economie & 1,4 & 7 & 10 \\
\hline Wo Letteren en sociaal-cultureel & 1,3 & 7 & 14 \\
\hline WO Medisch & 2,9 & 13 & 17 \\
\hline Totaal & 4,3 & 21 & 20 \\
\hline
\end{tabular}

* In De arbeidsmarkt naar opleiding en beroep tot 2006 zijn, op alle opleidingsniveaus, de opleidingsrichtingen 'Landbouw' en 'Techniek' samengevoegd tot 'Landbouw en techniek'.

Bron: ROA 
De tweedeling in vervangingsvraag tussen lager en hoger opgeleiden valt ook waar te nemen bij de middellange termijn prognoses. De lagere opleidingssectoren Basisonderwijs, VMBO Verzorging, VMBO Theorie, VMBO Techniek (en de middelbare opleidingssector MBO Dienstverlening en gezondheidszorg) hebben allen vervangingsvraagpercentages van $24 \%$ of groter. De opleidingen op HBO- of WO-niveau vertonen op de middellange termijn veelal een lage vervangingsvraag. Dit is geheel in lijn met de landelijke voorspellingen, al moet gezegd worden dat de verschillen tussen de onderscheiden opleidingssectoren op de Limburgse arbeidsmarkt iets meer uitgesproken zijn.

\section{KORTE TERMIJN:}

Opleidingstypen met een relatief hoge vervangingsvraag in Limburg:

- VMBO verzorging

- VMBO mechanische techniek

- HBO (fysio)therapie

- HBO lerarenopleiding economie en maatschappij

Opleidingstypen met een relatief lage vervangingsvraag in Limburg:

- HBO commerciële economie

- WO letteren

- WO bedrijfskunde

- WO econom(etr)ie

- WO wiskunde en natuurwetenschappen

- WO sociale wetenschappen

- WO rechten en bestuurskunde

\section{MIDDELLANGE TERMIJN:}

Opleidingstypen met een relatief hoge vervangingsvraag in Limburg:

- VMBO verzorging

- VMBO mechanische techniek

- VMBO vervoer

- MBO facilitaire dienstverlening

- HBO (fysio) therapie

- HBO lerarenopleiding economie en maatschappij

Opleidingstypen met een relatief lage vervangingsvraag in Limburg:

- HBO commerciële economie

- WO letteren

- WO bedrijfskunde

- WO econom(etr)ie

- WO wiskunde en natuurwetenschappen

- WO sociale wetenschappen

- WO rechten en bestuurskunde

In het bovenstaande schema wordt een overzicht gegeven van de meer specifieke opleidingen, warvoor de verwachte vervangingsvaag op de korte of middellange termijn in Limburg relaticf hoog of laag zal zijn. Ook op dit meer specifieke niveau blijkt dat de hoog- 
ste vervangingsvraag vooral voorkomt bij lagere opleidingstypen en een lagere vervangingsvraag vooral bij de hogere opleidingstypen. Onder deze hoger opgeleiden bevinden zich relatief veel jongeren. Daarnaast blijkt dat de ouderen onder de hoger opgeleiden minder snel de arbeidsmarkt uitstromen dan bij de lager opgeleiden. In het oog springende uitzonderingen zijn: $H B O$ (fysio)therapie en $H B O$ lerarenopleiding economie en maatschappij. In het overzicht van de prognoses van de vervangingsvraag voor de middellange termijn komen veelal dezelfde opleidingstypen voor als voor de korte termijn.

\subsection{Totale vraag naar schoolverlaters}

Wanneer we de prognoses van de uitbreidingsvraag en de vervangingsvraag combineren, dan geeft dit een indicatie van de totale verwachte vraag: de baanopeningen voor nieuwkomers op de Limburgse arbeidsmarkt. Bij een krimpende werkgelegenheid bestaat de totale vraag alleen uit de vervangingsvraag.

\section{Beroepsklassen}

Tabel 3.6 geeft een overzicht van de verwachte baanopeningen per beroepsklasse voor Limburg op korte en middellange termijn ${ }^{23}$. De grootste totale vraag naar nieuwkomers doet zich voor bij de Culturele beroepen met een totale vraag van $8,9 \%$. Verder bieden ook de Medische en paramedische beroepen en de Pedagogische beroepen op de korte termijn relatief veel baanopeningen. De Openbare orde- en veiligheidsberoepen, de Agrarische beroepen en de Transportberoepen hebben daarentegen naar verwachting in Limburg in 2002 een laag percentage baanopeningen. In alle drie beroepsklassen blijft op de korte termijn het percentage baanopeningen onder de $7 \%$ van het huidige aantal werkenden.

Op de middellange termijn zijn er in de Sociaal-culturele beroepen, de Economisch-administratieve beroepen en de Medische en paramedische beroepen relatief de meeste arbeidsplaatsen voor nieuwkomers. Aanmerkelijk minder banen komen daarentegen vrij bij de Technische en industrieberoepen, de Openbare orde-en veiligheidsberoepen en de Culturele beroepen. Voor de Culturele beroepen betekent dit een omslag ten opzichte van de korte termijn verwachting. Zoals reeds eerder is aangegeven is het, vanwege de andere aanpak van de vervangingsvraag naar beroep, weinig zinvol de baanopeningen naar beroepsklasse voor Limburg te vergelijken met de landelijke prognoses.

23 Het percentage baanopeningen naar beroepsklasse is op dit hogere aggregatieniveau vaak niet gelijk aan de som van de vervangingsvraag en de (niet-negatieve) uitbreidingsvraag. De verklaring hiervorr ligt in het feit dat de baanopeningen eerst per beroepsgroep worden bepaald en pas daarna worden opgeteld naar beroepsklasse. 
Tabel 3.6

Verwachte baanopeningen (als percentage van de werkgelegenheid) naar beroepsklasse in 2002 en in de periode 2001-2006, Limburg en Nederland

\begin{tabular}{lrrr} 
Beroepsklasse & $\begin{array}{r}\text { Limburg } \\
2002\end{array}$ & $\begin{array}{r}\text { Limburg } \\
2001-2006\end{array}$ & $\begin{array}{r}\text { Nederland } \\
2001-2006\end{array}$ \\
& $\%$ & $\%$ & 27 \\
\hline Pedagogische beroepen & 7,9 & 27 & 24 \\
Culturele beroepen & 8,9 & 22 & 18 \\
Agrarische beroepen & 5,9 & 24 & 17 \\
Technische en industrieberoepen & 7,5 & 24 & 17 \\
Transportberoepen & 6,3 & 29 & 23 \\
Medische en paramedische beroepen & 8,6 & 36 & 28 \\
Economisch-administratieve beroepen & 6,8 & 33 & 24 \\
Informaticaberoepen & 6,8 & 29 & 30 \\
Sociaal-culturele beroepen & 7,1 & 37 & 19 \\
Verzorgende en dienstverlenende beroepen & 7,2 & 31 & 21 \\
Openbare orde- en veiligheidsberoepen & 4,8 & 23 & $22^{*}$
\end{tabular}

* De percentages baanopeningen naar beroepsklasse in Limburg zijn niet goed te vergelijken met de landelijke cijfers, omdat in Limburg - vanwege de andere aanpak van de arbeidsaanbodprognoses per beroep ook de doorleerders moeten worden meegenomen in de berekening van de vervangingsvraag van het beroepenmodel.

Bron: $R O A$

In het volgende schema wordt een overzicht gegeven van de berocpsgroepen waarvoor de verwachte totale vraag in Limburg relatief hoog of juist relaticl laag is. Uit dit overzicht blijkt dat de beroepsgroepen met verhoudingsgewijs het grootste atutal baanopeningen sterk gedomineerd worden door de beroepen met de hoogste uitbreidingsvraag. Het is met andere woorden de groei van de werkgelegenheid die bepaalt watr het aantal baanopeningen voor nieuwkomers op de arbeidsmarkt het grootst is. De beroepen met het laagste aantal baanopeningen worden daarentegen gedomineerd door de beroepen met de laagste vervangingsvraag. Dit laatste hangt ook samen met het leit dat bij een dalende werkgelegenheid de vervangingsvraag van oudere door jongere arbeidskrachten doorgaans gewoon doorgang blijft vinden. De vervangingsvraag zorgt daarbij voor een soort bodem in de marki. 


\section{KORTE TERMIJN:}

Beroepsgroepen met een relatief hoog percentage baanopeningen in Limburg:

- Confectie-arbeiders

- Juridisch en fiscaal medewerkers

- Ziekenverzorgenden

- Weg- en waterbouwkundige vakkrachten

- Winkeliers

- Elektromonteurs

Beroepsgroepen met een relatief laag percentage baanopeningen in Limburg:

- Organisatiedeskundigen

- Kunstenaars

- Verzekeringsagenten

- Weg- en waterbouwkundig arbeiders

- Politie-agenten, onderofficieren en beveiligingsemployés

\section{MIDDELLANGE TERMIJN:}

Beroepsgroepen met een relatief hoog percentage baanopeningen in Limburg:

- Ziekenverzorgenden

- Accountants

- Leidinggevenden

- Activiteitenbegeleiders en medewerkers arbeidsbemiddeling

- Productieplanners

- Managers

\section{Beroepsgroepen met een relatief laag percentage baanopeningen in Limburg:}

- Schoen- en kleermakers

- Kunstenaars

- Verzekeringsagenten

- Weg-en waterbouwkundig arbeiders

- Politie-agenten, onderofficieren en beveiligingsemployés

\section{Opleidingssectoren}

Tabel 3.7 geeft een overzicht van de verwachte baanopeningen per opleidingssector in Limburg op de korte en middellange termijn. De baanopeningen naar opleidingssector geven meer variatie te zien dan de baanopeningen naar beroepsklasse. De uitschicters in positieve zin, voor de werkzoekenden, zijn hier de verzorgende en medische opleidingen VMBO Verzorging, MBO Dienstverlening en gezondheidszorg, HBO Paramedisch en WO Medisch. Ook voor de opleidingssector HBO Onderwijs en sociaal-cullurecl worden relatief veel baanopeningen voor nieuwkomers verwach. Het hoge percentage verwachte baanopeningen voor deze vijf opleidingssectoren heeft verschillende oorzaken. Bij de lagere opleidingen komt de hoge vraag voort uit de vervangingsvraag, terwijl bij de hogere en wetenschappelijke opleidingen ook de (sterk) positieve uitbreidingsvraag een rol speelt. Op de korte termijn is het aantal baanopeningen voor schoolverlaters daarentegen laag bij de opleidingen VMBO Landbouw en natuurlijke omgeving, VMBO Economic, MBO Landbouw en natuwlijke omgeving, WO Techniek, WO Letteren en sociaal-culturecl en WO Economic 
Tabel 3.7

Verwachte baanopeningen (als percentage van de werkgelegenheid) naar opleidingssector in 2002 en in de periode 2001-2006, Limburg en Nederland

\begin{tabular}{|c|c|c|c|}
\hline Opleidingssector & $\begin{array}{r}\text { Limburg } \\
2002 \\
\%\end{array}$ & $\begin{array}{r}\text { Limburg } \\
2001-2006\end{array}$ & $\begin{array}{r}\text { Nederland } \\
2001-2006\end{array}$ \\
\hline & $\%$ & $\%$ & \\
\hline Basisonderwijs & 5,1 & 27 & 33 \\
\hline VMBO Theorie & 4,8 & 24 & 23 \\
\hline VMBO Landbouw en natuurlijke omgeving & 2,4 & 11 & $19^{*}$ \\
\hline VMBO Techniek & 5,1 & 24 & $19^{*}$ \\
\hline VMBO Economie & 2,7 & 13 & 26 \\
\hline VMBO Verzorging & 6,4 & 31 & 22 \\
\hline HAVO/VWO & 5,3 & 36 & 41 \\
\hline MBO Landbouw en natuurlijke omgeving & 3,4 & 29 & $30^{*}$ \\
\hline MBO Techniek & 4,7 & 26 & $30^{*}$ \\
\hline MBO Economie & 5,3 & 26 & 27 \\
\hline MBO Dienstverlening en gezondheidszorg & 6,5 & 34 & 28 \\
\hline HBO Landbouw & 5,9 & 21 & $27^{*}$ \\
\hline HBO Techniek & 4,7 & 24 & $27^{*}$ \\
\hline HBO Economie & 4,7 & 30 & 31 \\
\hline HBO Onderwijs en sociaal-cultureel & 5,9 & 30 & 31 \\
\hline HBO Paramedisch & 6,7 & 48 & 38 \\
\hline WO Landbouw en milieukunde & - & - & $25^{*}$ \\
\hline WO Techniek & 2,8 & 19 & $25^{*}$ \\
\hline WO Economie & 3,5 & 33 & 38 \\
\hline WO Letteren en sociaal-cultureel & 3,2 & 27 & 35 \\
\hline WO Medisch & 7.6 & 23 & 18 \\
\hline Totaal & 5,4 & 30 & 30 \\
\hline
\end{tabular}

* In De arbeidsmarkt naar opleiding en beroep tot 2006 zijn, op alle opleidingsniveaus, de opleidingsrichtingen 'Landbouw' en 'Techniek' samengevoegd tot 'Landbouw en techniek'.

Bron: ROA

Op de middellange termijn komt de totale vraag naar nieuwkomers in Limburg in de periode 2001-2006 uit op 30\% van het totaal aantal werkenden aan het begin van de prognoseperiode; oftewel 5,4\% gemiddeld per jaar. Met uitzondering van VMBO Landbouw en natuulijke omgeving (11\%) en HBO Paramedisch (48\%) liggen de middellange termijn verwachtingen voor de verschillende opleidingssectoren redelijk dicht bijeen. De grote vraag komt voor HAVONWO en HBO Paramedisch vooral voort uit de hoge uitbreidingsvraag. Voor MBO Dienstverlening en gezondheidszorg is de vervangingsvraag echter de stuwende kracht achter de totale vraag. Tegenover de opleidingsectoren met relatief de meeste baanopeningen voor schoolverlaters op de middellange termijn, staan de opleidingssectoren waarbij er sprake is van een laag of zeer laag aantal baanopeningen. Met name VMBO Economic, VMBO Theoric, VMBO Landbouw en natuulijke ongeving. WO 
Techniek en WO Medisch hebben een relatief geringe totale vraag naar schoolverlaters. Vooral voor de opleidingssector WO Medisch is dit verrassend gezien de gunstige verwachtingen voor de korte termijn. Dit geringe aantal baanopeningen is deels het gevolg van een afnemende vervangingsvraag en van een substitutie van opgeleiden door (para)medische HBO-ers.

\section{KORTE TERMIJN:}

Opleidingstypen met een relatief hoog percentage baanopeningen in Limburg:

- MBO facilitaire dienstverlening

- $\mathrm{MBO}$ verpleging en verzorging

- HBO lerarenopleiding economie en maatschappij

- HBO maatschappelijk werk en hulpverlening

- HBO laboratorium

- HBO (fysio)therapie

Opleidingstypen met een relatief laag percentage baanopeningen in Limburg:

- VMBO landbouw en natuurlijke omgeving

- VMBO administratie, handel en textiel

- VMBO bouwtechniek

- MBO grafische techniek

- WO letteren

- WO bedrijfskunde

MIDDELLANGE TERMIJN:

Opleidingstypen met een relatief hoog percentage baanopeningen in Limburg:

- MBO facilitaire dienstverlening

- MBO procestechniek

- MBO sociaal-pedagogisch en welzijn

- HBO (fysio) therapie

- WO bedrijfskunde

- WO econom(etr)ie

Opleidingstypen met een relatief laag percentage baanopeningen in Limburg:

- VMBO landbouw en natuurlijke omgeving

- VMBO administratie, handel en textiel

- VMBO bouwtechniek

- MBO grafische techniek

- MBO handel

- HBO laboratorium

- WO wiskunde en natuurwetenschappen

In het bovenstaande schema wordt een overzicht gegeven van de opleidingstypen, waarvoor de verwachte totale vraag in Limburg op korte of middellange termijn relatief hoog of relatief laag zal zijn. Het grootste aantal baanopeningen doet zich zowel op de korte als op de middellange termijn voor bij opleidingen op MBO-niveau en hoger. Opvallend is verder dat de opleiding HBO laboratorium op de korte termijn een lage totale vraag naar schoolverla- 
ters heeft, maar op middellange termijn juist bij de opleidingen met hoge percentages baanopeningen staat. Opmerkelijk is eveneens dat op de korte en middellange termijn ook voor enkele opleidingen op WO-niveau relatief weinig baanopeningen worden verwacht.

\subsection{Aanbod van schoolverlaters}

In de voorgaande paragrafen zijn de verwachte ontwikkelingen aan de vraagzijde van de Limburgse arbeidsmarkt op de korte en de middellange termijn geschetst, resulterend in de baanopeningen voor nieuwkomers op de arbeidsmarkt. Als aanbod staat, naast de kortdurig werklozen, hier met name de verwachte arbeidsmarktinstroom van schoolverlaters tegenover ${ }^{24}$ In deze paragraaf wordt een overzicht gegeven van het aanbod van schoolverlaters op de arbeidsmarkt voor de korte en middellange termijn.

\section{Beroepsklassen}

Tabel 3.8 geeft een overzicht van de verwachte arbeidsmarktinstroom van schoolverlaters verbijzonderd naar beroepsklasse. Naar verwachting zullen de Pedagogische beroepen, samen met de Transportberoepen en, in iets mindere mate, de Technische en industrieberoepen, relatief de laagste arbeidsmarktinstroom hebben. Lage verwachte instroomcijfers in diverse beroepsklassen zijn het gevolg van een terugloop in de leerlingaantallen in de opleidingen die zich in belangrijke mate richten op deze beroepen. Dit kan het gevolg zijn van de verwachte arbeidsmarktperspectieven of de verwachte aard van het werk, die deze opleiding minder populair maken. Naast dergelijke rationele argumenten kan een lage arbeidsmarktinstroom ook veroorzaakt worden door de imagoproblemen waarmee bepaalde opleidingen kunnen kampen. In dat geval hebben studiekiezers een negatief beeld van de arbeidsmarktperspectieven van de studie of het uiteindelijke beroep. Dit argument wordt vooral vaak gehoord bij de technische opleidingen, de zorgopleidingen en de docentenopleidingen. Het is overigens niet altijd duidelijk in hoeverre een negatieve beeldvorming, of terechte verwachtingen met betrekking tot de inhoud van het werk en de loopbaanperspectieven de oorzaak zijn van de teruglopende leerlingaantallen bij deze opleidingen.

24 Met de arbeidsmarktinstroom van herintreders is reeds impliciet rekening gehouden bij het bepalen van de (netto) vervangingsvraag. 
Tabel 3.8

Verwachte arbeidsmarktinstroom van schoolverlaters naar beroepsklasse (als percentage van de werkgelegenheid), korte termijn (2002), en middellange termijn (2001-2006), Limburg*

Beroepsklasse

$\begin{array}{rr}\text { Limburg } & \text { Limburg } \\ 2002 & 2001-2006 \\ \% & \%\end{array}$

Pedagogische beroepen

Culturele beroepen

Agrarische beroepen

Technische en industrieberoepen

Transportberoepen

Medische en paramedische beroepen

Economisch-administratieve beroepen

Informaticaberoepen

Sociaal-culturele beroepen

$\begin{array}{ll}3,6 & 17\end{array}$

Verzorgende en dienstverlenende beroepen

Openbare orde- en veiligheidsberoepen

* In De arbeidsmarkt naar opleiding en beroep tot 2006 wordt de instroom van schoolverlaters naar beroepsklasse niet berekend, maar op indirecte wijze geïndiceerd.

Bron: ROA

Op een soortgelijke manier kunnen bepaalde beroeps- en opleidingssectoren ook populairder worden. Goede arbeidsmarktverwachtingen, en een (te) gunstige beeldvorming met betrekking tot de inhoud van de opleiding of het uiteindelijke beroep, kunnen leiden tot een hoge instroom van nieuwkomers op het desbetreffende arbeidsmarktsegment. Populaire beroepsklassen zijn bijvoorbeeld de Verzorgende en dienstverlenende beroepen, de Informaticaberoepen, de Sociaal-culturele beroepen en de Economisch-administratieve beroepen. Met name bij de Verzorgende en dienstverlenende beroepen is de relatief hoge instroom van schoolverlaters overigens ook het gevolg van de geringe arbeidsparticipatie van oudere vrouwen, waardoor de verhouding tussen de instroom en het aantal werkenden hoger uitvalt.

In het volgende schema wordt een overzicht gegeven van de lagere en middelbare beroepsgroepen, waarvoor de verwachte arbeidsmarktinstroom van schoolverlaters in Limburg relatief hoog of relatief laag zal zijn. 


\section{KORTE TERMIJN:}

Beroepsgroepen met een relatief hoge arbeidsmarktinstroom van schoolverlaters in Limburg:

- Bedrijfshoofden horeca

- Verzorgend personeel

- Hulpkrachten horeca en verzorging

- Activiteitenbegeleiders en medewerkers arbeidsbemiddeling

- Verkopers

- Verzekeringsagenten

Beroepsgroepen met een relatief lage arbeidsmarktinstroom van schoolverlaters in Limburg:

- Juridisch en fiscaal medewerkers

- Weg- en waterbouwkundige arbeiders

- Politie-agenten, onderofficieren en beveiligingsemployees

- Monteurs

- Bibliotheekassistenten

- Bouwvakkers

\section{MIDDELLANGE TERMIJN:}

Beroepsgroepen met een relatief hoge arbeidsmarktinstroom van schoolverlaters in Limburg:

- Activiteitenbegeleiders en medewerkers arbeidsbemiddeling

- Bedrijfshoofden horeca

- Verzorgend personeel

- Hulpkrachten horeca en verzorging

- Kantoorhulpen, inpakkers en colporteurs

- Productiemedewerkers

\section{Beroepsgroepen met een relatief lage arbeidsmarktinstroom} van schoolverlaters in Limburg:

- Agrarische bedrijfshoofden

- Juridisch en fiscaal medewerkers

- Politie-agenten, onderofficieren en beveiligingsemployees

- Monteurs

- Bouwvakkers

\section{Opleidingssectoren}

In tabel 3.9 wordt een overzicht gegeven van de verwachte arbeidsmarktinstroom van schoolverlaters naar opleidingssector. Daarbij worden alleen de lagere en middelbare opleidingssectoren in beeld gebracht, omdat het, zoals reeds eerder is aangegeven, voor de arbeidsmarki voor de hoger opgeleiden in Limburg minder zinvol is om uit te gaan van het regionale arbeidsaanbod. Hoger opgeleiden zijn immers aanmerkelijk mobieler dan de lager en middelbaar opgeleiden. 
Tabel 3.9

Verwachte arbeidsmarktinstroom van schoolverlaters naar opleidingssector (als percentage van de werkgelegenheid), korte termijn (2002), Limburg, en middellange termijn (20012006), Limburg en Nederland

\begin{tabular}{lrrr} 
Opleidingssector & Limburg & Limburg & Nederland \\
& 2002 & $2001-2006$ & $\%$ \\
& $\%$ & $2001-2006$ \\
\hline Basisonderwijs & 5,5 & 28 & 26 \\
VMBO Theorie & 4,9 & 25 & 25 \\
VMBO Landbouw en natuurlijke omgeving & 7,5 & 38 & $21^{*}$ \\
VMBO Techniek & 4,8 & 24 & $21^{*}$ \\
VMBO Economie & 6,9 & 35 & 31 \\
VMBO Verzorging & 6,7 & 33 & 27 \\
HAVO/NWO & 7,7 & 38 & 53 \\
MBO Landbouw en natuurlijke omgeving & 4,1 & 21 & $22^{*}$ \\
MBO Techniek & 4,2 & 21 & $22^{*}$ \\
MBO Economie & 4,6 & 23 & 22 \\
MBO Dienstverlening en gezondheidszorg & 5,8 & 29 & 24 \\
& & & 24 \\
Totaal (inclusief hogere en & & & \\
wetenschappelijke opleidingen) & 4,8 & 24 &
\end{tabular}

* In De arbeidsmarkt naar opleiding en beroep tot 2006 zijn, op alle opleidingsniveaus, de opleidingsrichtingen 'Landbouw' en 'Techniek' samengevoegd tot 'Landbouw en techniek'.

Bron: ROA

Deze Limburgse arbeidsmarktinstroomcijfers weerspiegelen grotendeels het landelijke beeld. De totale instroom is vergelijkbaar met die in Nederland als geheel en ook de verschillen met het landelijke beeld zijn niet groot. Voornaamste uitzonderingen zijn VMBO Landbouw en natuurlijke omgeving, VMBO Verzorging en MBO Dienstverlening en gezondheidszorg, waar de verwachte arbeidsmarktinstroom van schoolverlaters groter is dan landelijk. De sector HAVO/VWO daarentegen blijkt in Limburg een veel kleinere arbeidsmarktinstroom te hebben dan op landelijk niveau wordt verwacht.

In het volgende schema wordt een overzicht gegeven van de opleidingstypen, waarvoor de verwachte arbeidsmarktinstroom van schoolverlaters in Limburg relatief hoog of relatiel laag zal zijn. Uit het overzicht blijkt dat de arbeidsmarktinstroom van schoolverlaters een stabiele structuur heeft. Er zijn tussen de korte en de middellange termijnprognoses immers geen verschillen in de groepen die een grote of kleine uitstroom van schoolverlaters hebben. 


\section{KORTE TERMIJN:}

Lagere en middelbare opleidingstypen met een relatief

hoge arbeidsmarktinstroom van schoolverlaters in Limburg:

- VMBO horeca en levensmiddelentechniek

- VMBO administratie, handel en textiel

- MBO procestechniek

- MBO sociaal-pedagogisch en welzijn

- MBO uiterlijke verzorging

- MBO facilitaire dienstverlening

Lagere en middelbare opleidingstypen met een relatief

lage arbeidsmarktinstroom van schoolverlaters in Limburg:

- VMBO vervoer

- $\mathrm{MBO}$ vervoer

- MBO handel

- MBO openbare orde en veiligheid

\section{MIDDELLANGE TERMIJN:}

Lagere en middelbare opleidingstypen met een relatief

hoge arbeidsmarktinstroom van schoolverlaters in Limburg:

- VMBO horeca en levensmiddelentechniek

- VMBO administratie, handel en textiel

- MBO procestechniek

- MBO sociaal-pedagogisch en welzijn

- MBO uiterlijke verzorging

- MBO facilitaire dienstverlening

Lagere en middelbare opleidingstypen met een relatief

lage arbeidsmarktinstroom van schoolverlaters in Limburg:

- VMBO vervoer

- $\mathrm{MBO}$ vervoer

- MBO handel

- MBO openbare orde en veiligheid 


\section{Knelpunten en perspectieven op de Limburgse arbeidsmarkt}

Het vorige hoofdstuk gaf een overzicht van de verwachte ontwikkelingen aan de vraag-en aanbodkant van de Limburgse arbeidsmarkt op de korte en de middellange termijn. De verwachte arbeidsmarktsituatie die hieruit resulteert kan zowel vanuit werkgevers- als werknemersperspectief worden belicht. Voor werkgevers is het belangrijk dat zij een indicatie hebben van de verwachte knelpunten in de personeelsvoorziening in de beroeps-en opleidingssectoren waar zij personeel werven. Voor werkzoekenden en degenen die binnenkort hun opleiding afronden is het belangrijk om een indicatie te hebben van de arbeidsmarktperspectieven van mensen met hun opleidingsachtergrond en de verschillende beroepen waarin men naar werk kan gaan zoeken.

Op basis van de Indicator Toekomstige Arbeidsmarktperspectieven (ITA) kan worden geconcludeerd dat de arbeidsmarktperspectieven in alle beroepsgroepen gunstig zijn voor schoolverlaters. Omgekeerd geldt dat werkgevers in alle beroepsklassen met knelpunten in de personeelsvoorziening blijven kampen. De confrontatie van de toekomstige vraag en aanbod op de Limburgse arbeidsmarkt vanuit het perspectief van de werkgever wordt weergegeven door de Indicator Toekomstige Knelpunten in de personeelsvoorziening naar Beroep (ITKB). Deze geeft te zien dat werkgevers in 2002 nog in alle beroepsklassen met rekruteringsproblemen geconfronteend zullen worden. Op de middellange termijn zullen deze knelpunten voor verschillende berocpsklassen duidelijk afnemen.

Het vraagoverschot in de ruime zin is op de korte termijn gedefinieerd als het tekort aan directinzetbare werkzoekenden en schoolverlaters ten opzichte van de baanopeningen en vacatures voor 2002 in Limburg. Dit vraagoverschot voor lager en middelbaar opgeleiden zal in Limburg in 2002 naar verwachting ruim 9.000 personen bedragen.

De aansluitingsproblemen die door deze prognoses worden weerspiegeld, zijn veelal kwantitaticf van aard. Voor het merendeel van de beroepsgroepen waarvoor werkgevers in 2002 knelpunten in de personeelsvoorziening kunnen verwachten, gelde dat er namelijk ook te weinig nietwerkende werkzoekenden met een grotere afstand tot de arbeidsmarkt beschikbaar zijn. Zelfs wanneer men erin zou slagen alle aanwezige niet-direat inzetbare werkzoekenden om-dan wel bij te scholen, dan levert dit een potentieel aanbod aan personeel op dat nog altijd ontoereikend is om de knelpunten weg te werken. De beroepen waarvoor werkgevers met name knelpunten kunnen verwachten zijn zowel de technische beroepen als verzorgende en dienstverlenende beroepen. Aangezien de problemen vooral kwantitatief van aard zijn, kunnen we stellen dat het 'arbeidsmarktklaar' maken van werkzoekenden met een grotere afstand tot de arbeidsmarkt alleen niet voldoende zal zijn. Naast het bij- of omscholen van deze niet-direct inzetbare werkzoekenden, zal ook gedache moeten worden aan het bevorderen van de pendel vanuil het aangrenzende buitenland of het bevorderen van de participatie van de stille arbeidsrescrve, zoals vrouwen en ouderen. 


\subsection{Inleiding}

In dit hoofdstuk zal worden ingegaan op de gevolgen van de prognoses van de ontwikkelingen op de Limburgse arbeidsmarkt op de korte en de middellange termijn. De confrontatie van vraag en aanbod, zoals deze werden besproken in hoofdstuk 3 , geeft in paragraaf 4.2 om te beginnen de knelpunten in de personeelsvoorziening, weergegeven door de Indicator Toekomstige Knelpunten in de Personeelsvoorziening (ITKP). Tevens worden de arbeidsmarktperspectieven voor nieuwkomers op de arbeidsmarkt in beeld gebracht op basis van de Indicator Toekomstperspectieven op de Arbeidsmarkt (ITA).

Paragraaf 4.3 bespreekt vervolgens voor de lagere en middelbare beroepen in hoeverre de knelpunten waarmee werkgevers te kampen hebben op de arbeidsmarkt het hoofd geboden kunnen worden. Er zal uiteengezet worden in welke mate een vraagoverschot in de ruime zin verminderd kan worden door het inzetten van werkzoekenden met een grotere afstand tot de arbeidsmarkt. Hierbij zal in het bijzonder worden ingegaan op de mogelijkheden om door middel van bijscholing de werkzoekenden die door Arbeidsvoorziening zijn ingedeeld in fase 2 en 3 de knelpunten op de arbeidsmarkt te verminderen. Ten slotte zullen de bijscholingsmogelijkheden ook vanuit het perspectief van de werkzoekende zelf worden belicht. Hierbij gaat het om de vraag in hoeverre werkzoekenden die zijn ingedeeld in fase 2 en 3 door activering of het volgen van bijscholing goede mogelijkheden hebben om (weer) werk te kunnen krijgen.

\subsection{Perspectieven en knelpunten in de personeelsvoorziening in Limburg}

De Indicitor Toekomstige Arbeidsmarktperspectieven (ITA) is bedoeld voor schoolverlaters en geeft aan wat hun kansen op de arbeidsmarkt zijn. Voor degenen die nu voor een studiekeuzebeslissing staan zijn de perspectieven op middellange termijn van belang. Immers, pas op dat moment zal men doorgaans pas voor het eerst op zoek gaan naar een baan. Daarentegen zijn de perspectieven op de korte termijn zowel belangrijk voor de scholieren die in 2002 hun diploma behalen als de werklozen die momenteel op zoek zijn naar werk en daarbij overwegen om zich om te scholen naar een ander vakgebied via een relatief kortlopend scholingstraject. Een ITA die groter is dan één, duidt op een, voor schoolverlaters, ongunstige arbeidsmarkt. In dat geval is er meer aanbod dan vraag. Een ITA die kleiner is dan één, duidt daarentegen op een voor schoolverlaters gunstige arbeidsmarkt. Er is dan meer vraag dan aanbod.

Daarnaası geven we ook een indicator die zich richt op het perspectief van de werkgevers. De Indicator Toekomstige Knelpunten in de Personeelsvoorziening (ITKP) geeft aan hoeveel problemen werkgevers naar verwachting zullen ondervinden bij het aantrekken van geschikt personeel. De interpretatie van de ITKP is vergelijkbaar met die van de ITA. Een ITKP die groter is dan één, geeft aan dat er weinig problemen zullen optreden bij de werving van personeel op het desbetreffende segment van de arbeidsmarkt. Er is dan immers meer aanbod dan vraag. Omgekeerd, een ITKP die kleiner is dan één, duidt er op dat er meer vraag dan aanbod is, waardoor werkgevers met knelpunten in de personeelsvoorziening te kampen krijgen. 


\section{Beroepsklassen}

Tabel 4.1 presenteert beide indicatoren voor Limburg in 2002 per beroepsklasse. Wanneer we ons allereerst richten op de perspectieven voor schoolverlaters en werkzoekenden, dan zien we dat alle beroepsklassen de typering 'goed' krijgen. Op basis van de ITA in tabel 4.1 kan worden geconcludeerd dat de arbeidsmarktperspectieven in alle beroepsgroepen gunstig zijn voor schoolverlaters. Omgekeerd geldt dat werkgevers in alle beroepsklassen knelpunten in de personeelsvoorziening zullen blijven zien. De confrontatie van de toekomstige vraag en aanbod op de Limburgse arbeidsmarkt vanuit het perspectief van de werkgever via de ITKB laat zien dat men in alle beroepsklassen rekruteringsproblemen kan verwachten. Opmerkelijk genoeg zijn de knelpunten in de personeelsvoorziening in 2002 het grootst in de Agrarische beroepen. Overigens moet bij de over de gehele linie gunstige perspectieven voor schoolverlaters wel de kanttekening worden gemaakt dat de hier gepresenteerde prognoses geen onderscheid maken tussen de perspectieven van de schoolverlaters op de verschillende opleidingsniveaus. Daarvoor moet gekeken worden naar de perspectieven per opleidingssector in tabel 4.3 .

Tabel 4.1

Indicator Toekomstige Arbeidsmarktperspectieven (ITA) en Indicator Toekomstige Knelpunten in de personeelsvoorziening naar Beroep (ITKB) naar beroepsklasse, in 2002, Limburg

\begin{tabular}{|c|c|c|c|c|}
\hline Beroepsklasse & ITA & typering & ITKB & typering \\
\hline Pedagogische beroepen & 0,95 & goed & 0,96 & groot \\
\hline Culturele beroepen & 0,94 & goed & 0,98 & groot \\
\hline Agrarische beroepen & 0,92 & goed & 0,92 & groot \\
\hline Technische en industrieberoepen & 0,95 & goed & 0,97 & groot \\
\hline Transportberoepen & 0,98 & goed & 0,99 & groot \\
\hline Medische en paramedische beroepen & 0,95 & goed & 0,95 & groot \\
\hline Economisch-administratieve beroepen & 0,98 & goed & 0,99 & groot \\
\hline Informaticaberoepen & 0,98 & goed & 0,98 & groot \\
\hline Sociaal-culturele beroepen & 0,97 & goed & 0,98 & groot \\
\hline Verzorgende en dienstverlenende beroepen & 0,96 & goed & 0,96 & groot \\
\hline Openbare orde- en veiligheidsberoepen & 0,97 & goed & 0,98 & groot \\
\hline Totaal (inclusief hogere beroepen) & 0,96 & goed & 0,97 & groot \\
\hline
\end{tabular}

Bron: ROA

Tabel 4.2 geeft eenzelfde overzicht van de perspectieven en knelpunten op de arbeidsmarkt als tabel 4.1, maar dan voor de middellange termijn. Het beeld voor de schoolverlaters blijft veelal goed, alleen voor de Culturele beroepen zal het perspectief voor schoolverlaters iets minder gunstig worden. Daarentegen zijn de perspectieven voor degenen die werk zoeken in de Medische en paramedische beroepen op middellange termijn het gunstigst.

Het vooruitzicht vanuit het perspectief van de werkgever is op de middellange termijn iets minder somber dan op de korte termijn. Technische en industrieheroepen. Agrarische beroe- 
pen, Verzorgende en dienstverlenende beroepen en Culturele beroepen vertonen op de middellange termijn naar verwachting gemiddeld genomen geen grote knelpunten. Voor werkgevers in de Openbare orde- en veiligheidsberoepen worden zelfs vrijwel geen knelpunten verwacht. De rekruteringsproblematiek voor deze beroepsklasse is dus naar verwachting vooral een korte termijn probleem.

Tabel 4.2

Indicator Toekomstige Arbeidsmarktperspectieven (ITA) en Indicator Toekomstige Knelpunten in de personeelsvoorziening naar Beroep (ITKB) naar beroepsklasse, in de periode 2001-2006, Limburg

\begin{tabular}{|c|c|c|c|c|}
\hline Beroepsklasse & ITA & typering & ITKB & typering \\
\hline Pedagogische beroepen & 0,93 & goed & 0,95 & groot \\
\hline Culturele beroepen & 1,00 & redelijk & 1,01 & enige \\
\hline Agrarische beroepen & 0,99 & goed & 1,02 & enige \\
\hline Technische en industrieberoepen & 0,99 & goed & 1,05 & enige \\
\hline Transportberoepen & 0,99 & goed & 1,00 & groot \\
\hline Medische en paramedische beroepen & 0,90 & goed & 0,91 & groot \\
\hline Economisch-administratieve beroepen & 0,96 & goed & 0,98 & groot \\
\hline Informaticaberoepen & 0,98 & goed & 0,98 & groot \\
\hline Sociaal-culturele beroepen & 0,94 & goed & 0,94 & groot \\
\hline Verzorgende en dienstverlenende beroepen & 1,00 & goed & 1,01 & enige \\
\hline $\begin{array}{l}\text { Openbare orde- en veiligheidsberoepen } \\
\text { geen }\end{array}$ & 1,00 & goed & 1,07 & vrijwel \\
\hline Totaal (inclusief hogere beroepen) & 0,97 & goed & 1,00 & groot \\
\hline
\end{tabular}

Bron: $R O A$

In het volgende schema wordt een overzicht gegeven van de beroepsgroepen, waarvoor werkgevers relatief veel of relatief weinig knelpunten in de personeelsvoorziening kunnen verwachten in Limburg. 
KORTE TERMIJN:

Beroepsgroepen met relatief weinig rekruteringsproblemen voor werkgevers en relatief slechte arbeidsmarktperspectieven voor schoolverlaters in Limburg:

- Bibliotheekassistenten

- Laders en lossers

- Receptionisten en administratief employés

- Activiteitenbegeleiders en medewerkers arbeidsbemiddeling

- Verzekeringsagenten

Beroepsgroepen met relatief veel rekruteringsproblemen voor werkgevers en relatief gunstige arbeidsmarktperspectieven voor schoolverlaters in Limburg:

- Productiemedewerkers

- Confectie-arbeiders

- Weg- en waterbouwkundige vakkrachten

- Ziekenverzorgenden

- Juridisch en fiscaal medewerkers

- Hulpkrachten horeca en verzorging

\section{MIDDELLANGE TERMIJN:}

Beroepsgroepen met relatief weinig rekruteringsproblemen voorwerkgevers en relatief slechte arbeidsmarktperspectieven voor schoolverlaters in Limburg:

- Bibliotheekassistenten

- Productiemedewerkers

- Bouwvakkers

- Weg- en waterbouwkundige vakkrachten

- Weg- en waterbouwkundige arbeiders

Beroepsgroepen met relatief veel rekruteringsproblemen voor werkgevers en relatief gunstige arbeidsmarktperspectieven voor schoolverlaters in Limburg:

- Apothekersassistenten en medisch laboranten

- Verplegenden en doktersassistenten

- Boekhouders en secretaresses

- Juridisch en fiscaal medewerkers

- Ziekenverzorgenden

\section{Opleidingssectoren}

Tabel 4.3 geeft een overzicht van de arbeidsmarktperspectieven van de schoolverlaters en werkzoekenden in 2002 en de keerzijde daarvan vanuit het perspectief van de werkgever De confrontatie van vraag en aanbod heeft, zoals reeds eerder aangegeven, alleen betrekking op de lagere en middelbare opleidingen ${ }^{2 i}$. De tabel laat zien dat de schoolverlaters van

\footnotetext{
5 Omdat bij hoger opgeleiden veelal sprake is van een landelijke arbeidsmarkt, zijn hiervan geen vraag. aanbodvergelijkingen gemaakt voor de Limburgse arbeidsmarkı. Voor de landelijke prognoses van arbeidsmarktinstroom, knelpunten voor werkgevers en perspecticven voor schoolverlaters van de hogere en wetenschappelijke opleidingen, zie: De arbeidsmarke naar opleiding on beroep tot 2006. R()A-R-2001/8 Maastricht, 2001
} 
VMBO Techniek, VMBO Verzorging en alle opleidingen op het MBO-niveau op de korte termijn gunstige perspectieven hebben. Schoolverlaters van de richtingen VMBO Economie, VMBO Theorie, HAVO/VWO, Basisonderwijs en met name VMBO Landbouw en natuurlijke omgeving zullen daarentegen meer problemen kunnen verwachten bij het vinden van een baan. Een achterblijvende vraag, mede vanwege de upgrading van de kwalificatie-eisen in veel beroepen waarin mensen met deze opleidingsachtergrond traditioneel emplooi vinden, is hier vooral debet aan.

Tabel 4.3

Indicator Toekomstige Arbeidsmarktperspectieven (ITA) en Indicator Toekomstige

Knelpunten in de Personeelsvoorziening (ITKP) naar opleidingssector in 2002, Limburg

\begin{tabular}{|c|c|c|c|c|}
\hline Opleidingssector & ITA & typering & ITKB & typering \\
\hline Basisonderwijs & 1,01 & redelijk & 1,01 & enige \\
\hline VMBO Theorie & 1,01 & redelijk & 1,01 & enige \\
\hline VMBO Landbouw en natuurlijke omgeving & 1,06 & matig & 1,06 & vrijwel geen \\
\hline VMBO Techniek & 0,92 & goed & 0,92 & groot \\
\hline VMBO Economie & 1,05 & redelijk & 1,05 & enige \\
\hline VMBO Verzorging & 0,98 & goed & 0,98 & groot \\
\hline HAVO/NWO & 1,03 & redelijk & 1,03 & enige \\
\hline MBO Landbouw en natuurlijke omgeving & 1,00 & goed & 1,00 & groot \\
\hline MBO Techniek & 0,98 & goed & 0,98 & groot \\
\hline MBO Economie & 0,97 & goed & 0,97 & groot \\
\hline MBO Dienstverlening en gezondheidszorg & 0,98 & goed & 0,98 & groot \\
\hline Totaal (inclusief HBO en WO) & 0,98 & goed & 0,98 & groot \\
\hline
\end{tabular}

Bron: ROA

Beschouwen we de Limburgse arbeidsmarkt in 2002 vanuit het gezichtspunt van de werkgever, dan is te zien dat men dus vooral bij VMBO Techniek, VMBO Verzorging en de opleidingen op het MBO-niveau rekruteringsproblemen zal ondervinden. Daarbij zijn de knelpunten het grootst bij VMBO Techniek. Opmerkelijk is ook dat er naar verwachting vrijwel geen knelpunten hoeven op te treden bij werving van personeel met de opleiding VMBO Landbouw en natuurlijke omgeving. Dit betekent dat de in tabel 4.1 aangegeven knelpunten in de personeelsvoorziening in de Agrarische beroepen zich vooral zullen voordoen bij de geschoolde arbeidskrachten.

In tabel 4.4 worden voor de lagere en middelbare opleidingssectoren de arbeidsmarktperspectieven op de middellange termijn getoond. Het geschetste beeld is sterk in overeenstemming met de verwachting voor de korte termijn: gunstige perspectieven voor schoolverlaters van het MBO tegenover minder gunstige voor schoolverlaters met slechts Basisonderwijs of een VMBO-opleiding. Uitgesproken slecht zijn de vooruitzichten voor schoolverlaters van VMBO Landbouw en natuurlijke omgeving en VMBO Economie. Voor VMBO Techniek en VMBO Verzorging blijken de arbeidsmarktperspectieven na 2002 duidelijk af te nemen. Deze ontwikkelingen geven aan dat met name de lager opgeleiden gecon- 
fronteerd zullen worden met de gevolgen van de minder gunstige ontwikkeling van de Limburgse economie.

Limburgse werkgevers kunnen op de middellange termijn naar verwachting vooral problemen verwachten bij het vinden van geschikt personeel met een MBO-opleiding. Minder problemen in de personeelsvoorziening worden voorzien voor de lagere opleidingssectoren, met name VMBO Theorie, VMBO Technick en VMBO Verzorging, terwijl bij het aantrekken van 'ongeschoold' personeel en mensen met VMBO Landbouw en natuurlijke omgeving en VMBO Economie de knelpunten op de arbeidsmarkt naar verwachting geheel zullen zijn verdwenen.

Tabel 4.4

Indicator Toekomstige Arbeidsmarktperspectieven (ITA) en Indicator Toekomstige Knelpunten in de Personeelsvoorziening (ITKP) naar opleidingssector, in de periode 20012006, Limburg

\begin{tabular}{lclll} 
Opleidingssector & ITA & typering & ITKB & typering \\
\cline { 2 - 3 } Basisonderwijs & 1,01 & redelijk & 1,01 & geen \\
VMBO Theorie & 1,03 & redelijk & 1,05 & vrijwel geen \\
VMBO Landbouw en naturlijke omgeving & 1,26 & slecht & 1,76 & geen \\
VMBO Techniek & 1,02 & redelijk & 1,15 & vrijwel geen \\
VMBO Economie & 1,23 & slecht & 1,44 & geen \\
VMBO Verzorging & 1,05 & redelijk & 1,13 & vrijwel geen \\
HAVO/VWO & 1,03 & redelijk & 1,03 & enige \\
MBO Landbouw en natuurlijke omgeving & 0,94 & goed & 0,94 & groot \\
MBO Techniek & 0,97 & goed & 0,98 & groot \\
MBO Economie & 0,98 & goed & 0,99 & groot \\
MBO Dienstverlening en gezondheidszorg & 0,96 & goed & 0,98 & groot \\
Totaal (inclusief HBO en WO) & & & & \\
\end{tabular}

Bron: ROA

Voor sommige opleidingssectoren geeft de ITKP een veel groter aanbodoverschot aan dan de ITA. Dit is bijvoorbeeld het geval voor VMBO Landbouw en natuurlijke omgeving en VMBO Techniek. Een dergelijk verschil wordt veroorzaakt door een krimp in de werkgelegenheid. Een groot verschil tussen ITA en ITKP duidt er namelijk op dat de 'drop-outs' uit het initiële onderwijs direct na het verlaten van hun school nog wel een 'redelijk' arbeidsmarktperspectief hebben. Echter, de werkgelegenheidskrimp voor ongeschoolde arbeidskrachten komı geheel voor rekening van de mensen die zich reeds langer op de arbeidsmarkt bevinden. Bij verlies van hun baan vormen deze mensen geen concurrentie voor de ongeschoolde schoolverlaters die tegen een veel lager loon kunnen worden aangetrokken en vaak ook productiever zijn. Ongeschoolde arbeidskrachten die niet door het volgen van aanvullende scholing een 'startkwalificatie' voor de arbeidsmarkı op het MBOniveau van 'basisberoepsbeoefenaar' weten te behalen, komen derhalve in een soort fuik terecht. Hierdoor lopen deze ongeschoolden op relatief jonge leeftijd het risico langdurig werkloos te worden of de arbeidsmarkt geheel te verlaten. 
In het volgende schema wordt een overzicht gegeven van de opleidingstypen, waarvoor werkgevers relatief veel of relatief weinig knelpunten in de personeelsvoorziening kunnen verwachten (en schoolverlaters relatief goede of matige arbeidsmarktperspectieven). We zien vooral goede perspectieven bij MBO-opleidingen, en minder gunstige perspectieven bij VMBO-opleidingen. Opmerkelijk hierbij is ook dat bij de bouwopleiding op VMBO-niveau en MBO-niveau een tegengesteld beeld lijkt te ontstaan. Enerzijds wijst dit er op dat werkgevers hun aanstellingseisen op het $\mathrm{MBO}$-niveau van basisberoepsbeoefenaren leggen Anderzijds wijst het echter ook op mogelijkheden om de verwachte knelpunten in de personeelsvoorziening op MBO-niveau te verminderen door het opscholen van de VMBO'ers, die anders de boot dreigen te missen.

\section{KORTE TERMIJN:}

Opleidingstypen met relatief veel rekruteringsproblemen voor werkgevers en goede arbeidsmarktperspectieven voor schoolverlaters in Limburg:

- VMBO bouwtechniek

- VMBO vervoer

- MBO werktuigbouw en mechanische techniek

- MBO handel

- MBO sociaal-pedagogisch en welzijn

Opleidingstypen met relatief weinig rekruteringsproblemen voor werkgevers en matige arbeidsmarktperspectieven voor schoolverlaters in Limburg:

- VMBO landbouw en natuurlijke omgeving

- VMBO horeca en levensmiddelentechniek

- VMBO administratie, handel en textiel

- HAVO/VWO

- MBO uiterlijke verzorging

- MBO procestechniek

\section{MIDDELLANGE TERMIJN:}

Opleidingstypen met relatief veel rekruteringsproblemen voor werkgevers en goede arbeidsmarktperspectieven voor schoolverlaters in Limburg:

- VMBO vervoer

- $\mathrm{MBO}$ voeding, natuur en milieu

- $\mathrm{MBO}$ vervoer

- $\mathrm{MBO}$ verpleging en verzorging

- MBO openbare orde en veiligheid

Opleidingstypen met relatief weinig rekruteringsproblemen voor werkgevers en matige arbeidsmarktperspectieven voor schoolverlaters in Limburg:

- VMBO landbouw en natuurlijke omgeving

- VMBO bouwtechniek

- VMBO administratie, handel en textiel

- VMBO horeca en levensmiddelentechniek

- MBO uiterlijke verzorging 


\subsection{Aandachtspunten voor een vraaggericht scholingsbeleid in Limburg}

\section{Vraagoverschot in de ruime zin}

Naar aanleiding van de in paragraaf 4.2 belichte toekomstige knelpunten in de personeelsvoorziening voor Limburg op de korte en de middellange termijn, zal in deze paragraaf worden ingegaan op de vraag in hoeverre bijscholing van werkzoekenden met een grotere afstand tot de arbeidsmarkt soelaas kan bieden. Omdat het bij de scholing van werkzoekenden doorgaans gaat om relatief korte opleidingstrajecten beperken we ons hierbij tot de korte termijn. Gezien de geringe toepasbaarheid van dergelijke inzichten op het hoge aggregatieniveau, zoals dat tot nu toe in dit hoofdstuk is gehanteerd, volgt nu een uiteenzetting gericht op de gedetailleerde indeling naar beroepsgroep. De hogere en wetenschappelijke beroepen blijven hierbij buiten beschouwing, omdat voor deze functies, zoals gezegd, veeleer sprake is van een landelijke arbeidsmarkı.

De in deze paragraaf gepresenteerde cijfers kunnen een richtsnoer bieden voor de invulling van een marktconform scholingsbeleid voor de werkzoekenden met een wat grotere afstand tot de arbeidsmarkt. We kunnen in dit geval ook spreken van een vraaggericht scholingsbeleid. Vanuit het perspectief van de werkzoekenden geeft dit overigens een beeld van waar op de arbeidsmarkt vooral hun kansen liggen, wanneer zij door bij- of omscholing hun arbeidsmarktperspectieven willen verbeteren.

Het verschil tussen de verwachte baanopeningen en de openstaande vacatures aan de ene kant en het verwachte aantal schoolverlaters en direct inzetbare niet-werkende werkzoekenden aan de andere kant geeft een indicatie van het vraagoverschot in de ruime zin voor de betreffende beroepsgroep. De omvang van dit vraagoverschot is van twee factoren afhankelijk. In de eerste plaats van de ernst van de verwachte knelpunten. Hoe groter de knelpunten, des te groter het vraagoverschot in de ruime zin zal zijn. In de tweede plaats is het verwachte vraagoverschot in de ruime zin (in aantallen personen) afhankelijk van de omvang van het arbeidsmarktsegment.

Vraagoverschotten kunnen op verschillende manieren worden verminderd. Daarbij kan gedacht worden aan scholing, het bevorderen van de internationale pendel of het inzetten van een deel van de stille arbeidsreserve. Op deze laatste twee mogelijkheden om het inzetbare arbeidsaanbod in Limburg te vergroten zal in hoofdstuk 5 nader worden ingegaan.

Tabel 4.5 geeft voor de lagere en middelbare beroepsgroepen een overzicht van het vraagoverschot in de ruime zin in Limburg in 2002. Deze tabel beperkt zich tot de beroepen met een vraagoverschot van (afgerond) minimaal 100 personen. Verder is in de tabel een kolom opgenomen met het aantal beschikbare niet-werkende werkzoekenden met een grotere afstand tot de arbeidsmarkt dan de direct inzetbare werkzoekenden ${ }^{26}$.

Het eerste dat in het oog springt is dat het totale verwachte vraagoverschot in de ruime zin van 9.250 kleiner is dan voor het jaar 2001, waarvoor een vraagoverschol van 13.000

26 De niet-werkende werkzoekenden vallen onder de fasen 2 en 3 volgens de indeling van Arbeidsvoorziening. 
mensen werd voorspeld. Met name de afgenomen groeiverwachtingen zijn debet aan deze afname. Het lagere verwachte vraagoverschot hoeft niet noodzakelijkerwijs een verslechtering van de perspectieven van bij- en omscholing in te houden. Dat hangt onder andere af van het aantal niet-werkende werkzoekenden.

Tabel 4.5 laat zien dat er naar verwachting ruim 6.500 werkzoekenden met een grotere afstand tot de arbeidsmarkt beschikbaar zullen zijn. De lijst van tabel 4.5 wordt aangevoerd door de beroepsgroep boekhouders en secretaresses. Voor deze beroepsgroep wordt een vraagoverschot in de ruime zin van 1.050 mensen verwacht. Het vraagoverschot van de lijstaanvoerder van de vorige keer, hulpkrachten horeca en verzorging, zal naar verwachting dalen van 1.500 naar 800 . Vielen de vorige keer de chauffeurs op omdat hun vraagoverschot in de ruime zin tussen 2000 en 2001 een sprong makte van 300 naar 1.400 , nu is het omgekeerde het geval: een terugval naar 450. Deze zigzagbeweging is waarschijnlijk toe te schrijven aan de grote conjunctuurgevoeligheid van de arbeidsmarkt voor deze beroepsgroep.

Kunnen werkzoekenden met een grotere afstand tot de arbeidsmarkt soelaas bieden om de verwachte arbeidsmarktknelpunten te kunnen verminderen? Voor de beroepen in tabel 4.5 is er een aanbod van 6.550 werkzoekenden in fase 2 of 3 tegenover het vraagoverschot van 9.250. Puur naar het totaal gekeken, schiet dit aanbod dus te kort. Dit geldt echter niet voor alle onderliggende beroepen. Voor vijf beroepen in tabel 4.5 is het aantal niet-direct inzetbare, niet-werkende werkzoekenden wel degelijk toereikend om de verwachte vacatures te vullen. De beroepsgroepen boekhouders en secretaresses, productiemedewerkers, chauffeurs, kantoorhulpen, inpakkers en colporteurs en verkopers hebben allemaal voldoende werkzoekenden in fase 2 of $3 \mathrm{om}$ het voorspelde vraagoverschot in de ruime zin teniet te doen. Voor deze beroepen geldt dat er meer dan voldoende niet-direct inzetbare werkzoekenden aanwezig zijn. Het probleem is hier derhalve niet zozeer het ontbreken van aanbod, maar het geschikt maken van het niet-direct inzetbare aanbod. Het zal hier waarschijnlijk gaan om mensen wiens vaardigheden (gedeeltelijk) verouderd zijn, of die om andere redenen hulp en begeleiding nodig hebben voordat ze inzetbaar zijn op de arbeidsmarkt. Voor alle andere beroepsgroepen in tabel 4.5 zijn de mogelijkheden om door een vraaggericht bijscholingsbeleid, gericht op de niet-direct inzetbare werkzoekenden de knelpunten op de arbeidsmarkt te doen verdwijnen, minder gunstig. 
Tabel 4.5

Verwacht vraagoverschot in de ruime zin en beschikbare niet-werkende werkzoekenden (fase 2 en 3) per beroepsgroep, in 2002, Limburg

Beroepsgroep

Boekhouders en secretaresses

Productiemedewerkers

Aannemers en installateurs

interieurverzorgers

Hulpkrachten horeca en verzorging

Verplegenden en doktersassistenten

Winkeliers

Elektromonteurs

Chauffeurs

Ziekenverzorgenden

Bankwerkers en lassers

Metaalarbeiders

Confectie-arbeiders

Mechanisch operators

Kantoorhulpen, inpakkers en colporteurs

Aspirant politieagenten, soldaten en

beveiligingshulpkrachten

Productieplanners

Verkopers

Agrarische arbeiders

Grafische vakkrachten

Totaal (lagere en middelbare beroepen met een

vraagoverschot in de ruime zin van minimaal 100)
Vraagoverschot

in de ruime zin

Fase 2 en 3

werkzoekenden

\begin{tabular}{|c|c|}
\hline 1.050 & 1.300 \\
\hline 950 & 1.500 \\
\hline 900 & 100 \\
\hline 850 & 600 \\
\hline 800 & 600 \\
\hline 600 & 150 \\
\hline 600 & . \\
\hline 500 & 50 \\
\hline 450 & 800 \\
\hline 450 & - \\
\hline 350 & 100 \\
\hline 300 & 50 \\
\hline 300 & - \\
\hline 250 & - \\
\hline 200 & 600 \\
\hline 200 & 150 \\
\hline 150 & - \\
\hline 150 & 500 \\
\hline 100 & 50 \\
\hline 100 & - \\
\hline 9.250 & 6.550 \\
\hline
\end{tabular}

Bron: Arbeidsvoorziening/ROA

\section{Bijscholing}

Bijscholing kan een belangrijk instrument zijn om de arbeidsmarktkansen van nietwerkende werkzoekenden in fase 2 en 3 te vergroten. De verwachte knelpunten in de personeelsvoorziening voor de beroepsgroep waarin deze werkzoekenden op zoek zijn naar een baan spelen vanzelfsprekend een belangrijke rol voor het perspectief dat scholingsprojecten voor deze groepen kunnen hebben. Wanneer er sprake is van een ruime arbeidsmarkt zijn er immers voldoende direct inzetbare werkzoekenden beschikbaar, waardoor scholing van de niet-werkende werkzoekenden in fase 2 en 3 weinig perspectiefvol is. Wanneer er daarentegen op een bepaald arbeidsmarktsegment sprake is van krapte en er grote knelpunten in de personeelsvoorziening verwacht worden, kan scholing de niet-werkende werkzoekenden met een grotere afstand tot de arbeidsmarkt een goed perspectief bieden op het vinden van werk. 
Naast de vraag of er sprake is van verwachte knelpunten, speelt ook de aard van de knelpunten een rol. Wanneer voor een bepaalde beroepsgroep met knelpunten in de personeelsvoorziening het aantal niet- werkende werkzoekenden met een grotere afstand tot de arbeidsmarkt tekortschiet om de resterende baanopeningen in te vullen, dan is er sprake van een kwantitatief tekort aan werkzoekenden. In dat geval zullen de bijscholingsmogelijkheden voor individuele werkzoekenden in fase 2 en 3 naar verwachting groot zijn. De bijscholingsmogelijkhedenindicator (BSM) weerspiegelt de verhouding tussen het aantal niet-werkende werkzoekenden in fase 2 en 3 en de (resterende) vraag die niet door schoolverlaters en niet-werkende werkzoekenden in fase 1 kan worden vervuld. Een BSM kleiner dan één duidt op goede perspectieven voor de niet-direct inzetbare werkzoekenden om door bijscholing in hun eigen beroepsgroep aan het werk te komen.

Tabel 4.6 geeft een overzicht van de beroepsgroepen met een kwantitatief aansluitingsprobleem. Oftewel, de beroepsgroepen waarvoor individuele werkzoekenden een goede kans maken na bijscholing een baan te vinden in hun eigen beroepsgroep. Dit zijn beroepen met een vraagoverschot in de ruime zin dat groter is dan het aantal niet-direct inzetbare werkzoekenden. Dit betekent dus voor een individuele werkzoekende dat het zin heeft zichzelf 'arbeidsmarktklaar' te maken. De bijscholingsmogelijkhedenindicator (BSM) geeft de verhouding weer van het aanbod van niet-werkende, niet-direct inzetbare werkzoekenden (fase 2 en 3) en het verwachte vraagoverschot in de ruime zin na inzet van schoolverlaters en nietwerkende werkzoekenden in fase 1 .

Tabel 4.6

Beroepsgroepen met naar verwachting goede bijscholingsmogelijkheden (BSM) voor individuele werkzoekenden, in 2002, Limburg

\begin{tabular}{llll} 
Beroepsgroep & BSM & Vereist opleidingstype \\
Confectie-arbeiders & 0,00 & Basisonderwijs, VMBO textiel en mode \\
Winkeliers & 0,01 & Basisonderwijs, VMBO theorie, MBO handel \\
Mechanisch operators & 0,02 & Basisonderwijs, VMBO theorie \\
Ziekenverzorgenden & 0,03 & MBO verzorging \\
Elektromonteurs & 0,05 & MBO elektrotechniek \\
Aannemers en installateurs & 0,09 & - \\
Productieplanners & 0,09 & MBO administratie \\
Metaalarbeiders & 0,14 & VMBO metaal: fijnmechanische techniek \\
Grafische vakkrachten & 0,20 & - \\
Verplegenden en doktersassistenten & 0,23 & MBO verzorging \\
Bankwerkers en lassers & 0,37 & - \\
Interieurverzorgers & 0,71 & Basisonderwijs, VMBO (uiterlijke) verzorging \\
Agrarische arbeiders & 0,71 & Basisonderwijs, MBO landbouw en veeteelt \\
Hulpkrachten horeca en verzorging & 0,73 & Basisonderwijs, MBO (uiterlijke) verzorging \\
Aspirant politieagenten, soldaten & & \\
en beveiligingshulpkrachten & 0,79 & - \\
\hline
\end{tabular}

Bron: ROA 
Voor een aantal beroepsgroepen is de waarde van de BSM-indicator erg laag. Dit betekent dat er in deze beroepsgroepen vrijwel geen werkzoekenden beschikbaar zijn die zijn ingedeeld in fase 2 en 3. De bijscholingsmogelijkheden voor de weinige werkzoekenden in deze beroepen zijn dus ronduit goed te noemen. Hoewel dit betekent dat de enkele nietwerkende werkzoekende in principe erg gevraagd is, geldt tegelijkertijd voor werkgevers dat er, zowel absoluut als relatief gezien, zeer weinig aanbod van arbeidskrachten bestaat met een grotere afstand tot de arbeidsmarkt dat door bijscholing geschikt zou kunnen worden gemaakt om de openstaande vacatures te vervullen. Het aantal fase 2 en 3 werkzoekende confectie-arbeiders is in Limburg feitelijk te verwaarlozen. Voor de andere beroepsgroepen geldt dat er weliswaar enig aanbod van niet-direct inzetbaren aanwezig is, maar dat dit voor werkgevers nog altijd ontoereikend is om de rekruteringsproblemen het hoofd te bieden. Individuele werkzoekenden zullen, mits zij erin slagen zichzelf voldoende inzetbaar te maken, echter een goede kans hebben op het vinden van een baan in hun eigen beroepsgroep. Algemeen kunnen we stellen dat het hier vooral gaat om de Technische en industrieberoepen en de Verzorgende en dienstverlenende beroepen. Zo zien we bijvoorbeeld dat voor elke 100 ziekenverzorgenden die men nog nodig heeft na het inzetten van de beschikbare schoolverlaters en direct-inzetbare werkzoekenden, er slechts 3 werkzoekenden met een grotere afstand tot de arbeidsmarkt beschikbaar zijn.

Knelpunten in de personeelsvoorziening kunnen ook het gevolg zijn van een kwalitatief aansluitingsprobleem bij een bepaald beroep. In dat geval zijn er voor die beroepsgroep voldoende niet-werkende werkzoekenden in fase 2 en 3 beschikbaar om de baanopeningen die niet door schoolverlaters en werkzoekenden in fase 1 kunnen worden vervuld in te vullen. Deze werkzoekenden voldoen echter niet aan de eisen die op het betreffende arbeidsmarktsegment worden gesteld. Het probleem is dus kwalitatief van aard. De bijscholingsmogelijkhedenindicator (BSM), die het bijscholingspotentieel in verhouding tot het vraagoverschot weergeeft, is dan groter dan éen. Dit geeft aan dat slechts een deel van de niet-werkende werkzoekenden in fase 2 en 3 door bijscholing een baan zal kunnen krijgen in hun eigen beroepsgroep. Anderen zullen zich moeten laten omscholen voor ander werk.

Tabel 4.7 toont ons de vijf beroepsgroepen met een kwalitatief aansluitingsprobleem. Voor deze beroepsgroepen geldt dat er voldoende niet-direct inzetbare werkzoekenden in fase 2 en 3 aanwezig zijn om het verwachte vraagoverschot in de ruime zin op te vullen. Vooral de dienstverlenende beroepen verkopers en kantoorhulpen, inpakkers en colporteurs kennen een waarlijk stuwmeer van potentieel geschikte werkzoekenden. Zoals de tabel aangeeft blijkt dat de meeste van deze beroepen in de praktijk door mensen met een uiteenlopend opleidingsniveau worden uitgevoerd. Omdat slechts een deel van de niet-direct inzetbare werkzoekenden door bijscholing werk zou kunnen vinden in de eigen beroepsgroep is hel waarschijnlijk het meest perspectiefvol om de bijscholing te richten op degenen met de beste opleidingsachtergrond. 
Tabel 4.7

Beroepsgroepen met naar verwachting grote knelpunten in de personeelsvoorziening, maar met beperkte bijscholingsmogelijkheden (BSM) voor individuele werkzoekenden, in 2002. Limburg

Beroepsgroep

Verkopers

Kantoorhulpen, inpakkers en colporteurs

Chauffeurs

Productiemedewerkers

Boekhouders en secretaresses
BSM Vereist opleidingstype

3,57 Basisonderwijs, VMBO theorie, MBO handel

3,18 Basisonderwijs, VMBO theorie

1,72 Basisonderwijs, VMBO transport

1,59 Basisonderwijs, VMBO theorie

$1,25 \quad \mathrm{MBO}$ administratie, MBO secretariaat

Bron: $R O A$

\section{Omscholing}

Wanneer er sprake is van een kwantitatief aansluitingsprobleem, zoals het geval is bij de beroepen in tabel 4.6, dan is bijscholing van de niet-werkende werkzoekenden in fase 2 en 3 voor het betreffende beroep niet toereikend om de verwachte knelpunten in de personeelsvoorziening te voorkomen. In dat geval is omscholing van niet-werkende werkzoekenden op een enigszins verwant beroepssegment noodzakelijk om in de vraag te voorzien. Deze mensen zullen vanzelfsprekend moeten worden aangetrokken uit arbeidsmarktsegmenten waarvoor geen knelpunten in de personeelsvoorziening verwacht worden. Het omscholen van arbeidskrachten uit segmenten waarvoor eveneens sprake is van knelpunten is immers weinig efficiënt.

In tabel 4.8 zijn nogmaals de beroepen uit tabel 4.6 weergegeven. $\mathrm{Nu}$ is ook aangegeven op welke beroepsgroepen de omscholing zich zou moeten richten. De beroepsgroepen in de tweede kolom hebben zelf geen of weinig verwachte knelpunten, dat wil zeggen hebben te maken met een vraagtekort in Limburg in 2002, en kunnen dus worden ingezet ter vermindering van de knelpunten die werkgevers ervaren voor de beroepen in de eerste kolom. De tabel laat zien dat met name de omscholing van werkzoekenden in de beroepsgroepen verzorgend personecl, vakkenvullers en het grafisch productiepersoneel een bijdrage zou kunnen leveren om de vraagoverschotten in de ruime zin in verwante beroepsgroepen te verminderen. 


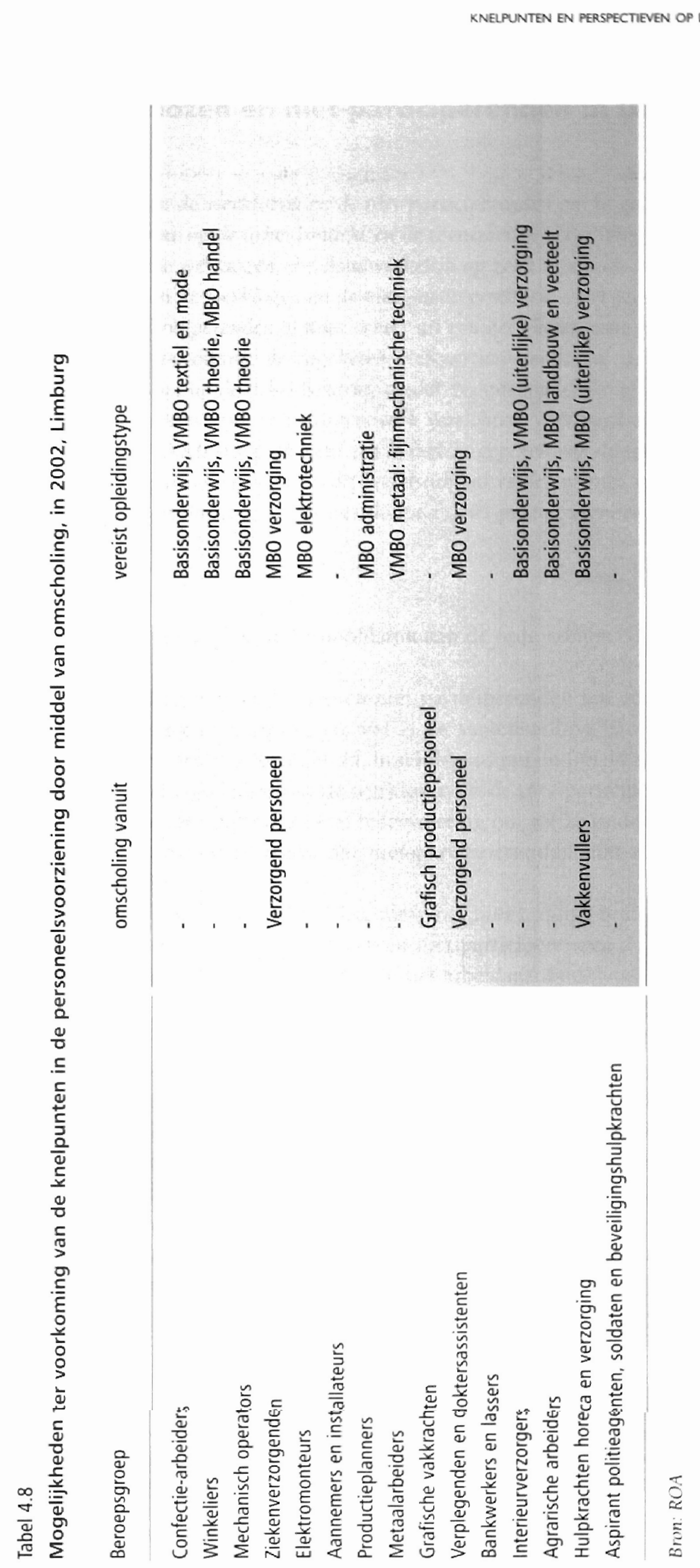




\section{De werklozen en niet-participerenden in Limburg}

Het stimuleren van de werklozen en de niet-participerenden om te gaan werken is vanwege de voortdurende krapte op de arbeidsmarkt en de toenemende vergrijzing van de beroepsbevolking zeer belangrijk. De werklozen, die daadwerkelijk op zoek zijn naar betaald werk, vormen een belangrijk deel van de werklozen en de niet-participerenden ${ }^{27}$. Het grootste deel van de werklozen en de niet-participerenden bestaat echter uit een zeer heterogene groep van personen uit de potentiële beroepsbevolking, de zogeheten niet-participerenden of stille reserve. Deze mensen bieden zich niet aan op de arbeidsmarkt, omdat ze huishoudelijke of zorgtaken hebben, studeren, arbeidsongeschikt zijn, vrijwilligerswerk verrichten, vervroegd met pensioen zijn gegaan, etc. ${ }^{28}$ In het vorige RAIL-rapport werd een overzicht gegeven van de samenstelling van de werklozen en de niet-participerenden. In dit hoofdstuk zal verder worden ingegaan op de bereidheid en de eventuele belemmeringen van werklozen en niet-participerenden om te gaan werken.

\subsection{Inleiding}

De volgende vragen zullen in dit hoofdstuk aan de orde komen:

- Hoe groot is de groep werklozen en niet-participerenden ten opzichte van de werkende beroepsbevolking in Limburg en wat is de samenstelling van deze groep naar onder andere geslacht, leeftijd, bereidheid, beschikbaarheid en opleidingsachtergrond?

- Wat is het arbeidsverleden van de werklozen en de niet-participerenden?

- In hoeverre vormen zorgtaken een belemmering om toe te treden tot de arbeidsmarkt?

- Wat is de belangrijkste reden dat niet-participerenden niet toe willen treden tot de arbeidsmarkt?

- Hoe tevreden zijn de niet-participerenden met hun huidige bezigheden?

- In hoeverre heeft de groep werklozen en niet-participerenden de juiste opleidingsachtergrond om in te springen bij tekorten in het arbeidsaanbod?

In paragraaf 5.2 zal worden ingegaan op de vraag hoe groot de groep werklozen en nietparticiperenden is en wat de samenstelling van deze groep is. In paragraal 5.3 zal dieper worden ingegaan op het arbeidsverleden van de werklozen en de niet-participerenden. In paragraaf 5.4 zal worden ingegaan op de belemmeringen om toe te treden (met name hel effect van zorgtaken) en de tevredenheid met huidige bezigheden van de werklozen en de niet-participerenden. In paragraal $5.5 \mathrm{zal}$ de opleidingsachtergrond van de niet-participerenden vergeleken worden met de toekomstige knelpunten naar opleidingscategorie. Dit om de geschiktheid voor het oplossen van tekorten van de werklozen en de niet-participerenden in te kunnen schatten.

27 Er wordı hier uitgegaan van werklozen volgens hel begrip 'werkloze beroepsbevolking'. Het CBS beschouw alleen personen als werkloos indien ze een baan van 12 uur of meer zoeken. Werklozen zijn volgens de definitie van de werkloze beroepsbevolking van het CBS de laatste vier weken op enigerlei wijze op zoek geweest naar een baan, en zijn in principe binnen wee weken beschikbaar voor een baan van 12 uur of meer. Zie de publicatie Enquête Beroepsbevolking 1999. CBS, 2000.

28 Scholieren en studenten zullen in de analyses buiten beschouwing blijven. 


\subsection{Omvang en samenstelling van de werklozen en de niet-participerenden}

Er zijn drie groepen in de werklozen en de niet-participerenden te onderscheiden:

- Personen die op zoek zijn naar werk en beschikbaar zijn voor de arbeidsmarkt, de werklozen;

- Personen die weliswaar geen werk zoeken maar wel beschikbaar zijn voor de arbeidsmarkt, de beschikbare niet-participerenden;

- Personen die niet beschikbaar zijn voor de arbeidsmarkt, de niet beschikbare niet-participerenden.

De niet-werkenden worden ingedeeld in deze drie groepen op basis van hun bereidheid om te werken. Indien men naar een baan zoekt, wordt er een grotere bereidheid getoond om werk te aanvaarden. Bovendien geeft de termijn waarop men een betaalde baan kan of wil aanvaarden, aan in welke mate iemand bereidheid is om betaald werk te verrichten ${ }^{29}$.

Onder niet-participerenden rekent men degenen die niet kunnen werken, niet willen werken, niet zoeken naar werk of niet op korte termijn beschikbaar zijn om werk te aanvaarden. Er zijn vele niet-participerenden die niet geschikt zijn om te werken omdat ze arbeidsongeschikt zijn. Binnen deze heterogene groep zijn er echter ook niet-participerenden die wel beschikbaar zijn voor de arbeidsmarkt, maar niet zoeken naar betaald werk. Dit zijn de beschikbare niet-participerenden, die zich op het grensvlak van werkloosheid en non-participatie bevinden. Deze groep wordt wel aangeduid als discouraged workers ${ }^{30}$. Deze laatste term heeft betrekking op de gedachte dat mensen ontmoedigd kunnen zijn door een slechte algemene arbeidsmarktsituatie met een hoge werkloosheid, waardoor ze geen zoekactiviteiten ontplooien. Ook kunnen mensen na enige tijd werkloos te zijn geweest ontmoedigd raken omdat ze nog steeds geen baan hebben gevonden ${ }^{31}$. Iemand die dan stopt met zoeken zal niet meer als werkloze worden beschouwd terwijl hij of zij wel beschikbaar is voor de arbeidsmarkt ${ }^{32}$. In dit licht bezien is het te verklaren dat het reservoir van niet-participerenden ook wel de 'stille reserve' genoemd wordt.

Tabel 5.1 laat de omvang van de werkloze en de niet-participerende beroepsbevolking zien. De niet-participerenden zijn opgesplitst in twee groepen: de beschikbare en de nietbeschikbare niet-participerenden. In de tabel wordt de beschikbare groep verder opgesplitst in degenen die werk gezocht hebben en degenen die dat niet hebben gedaan. De groep die

29 Het CBS hanteert hierbij in principe een grens van twee weken, maar hanteert een ruimere grens van drie maanden als dit nodig is vanwege cen opzegtermijn van de huidige werkkring (met cen baan van minder dan 12 uur), het afronden van vrijwilligerswerk, het moeten regelen van kinderopvang of wegens ziekte of vakantic.

30 Zie S.R.G. Jones and W.G. Riddell, 'Unemployment and Labor Force Attachment', in: J. Haltiwanger, M.E. Manser en R. Topel (eds), Labor Statistics Measurement lssues, NBER Studies in Income and Wealth, Volume 60, Chicago/London, 1998.

31 G. J. van den Berg. Search Behaviour, Transitions to Non-Participation and the Duration of Uncmployment, Economic Journal, Vol. 100, 1990, pp. 842-865.

$32 \mathrm{Het}$ is overigens ook mogelijk dat in huishoudens waarvan de werkende man onverwachts onvrijwillig werkloos word, de niet-participerende huisvrouw zich ook op de arbeidsmarkt gaat aanbieden om het verlies aan inkomen op te vangen. Dit added worker effect op het arbeidsaanbod van vrouwen in een laagconjunctuur is cchter veel kleiner dan het discouraged worker effect. Zie bijv. M. Stephens, Worker displacement and the added worker effect, NBER. Working Paper, No. 8260, 2001 
zich beschikbaar stelt maar niet naar werk gezocht heeft is veel groter dan de groep die wel gezocht heeft. De niet-beschikbare personen kunnen worden ingedeeld in vier groepen: personen die niet op korte termijn beschikbaar zijn, personen die geen werk willen, degenen die vervroegd zijn uitgetreden of met pensioen zijn en arbeidsongeschikten die niet beschikbaar maar in principe wel bereid zijn om te werken. De groep die geen behoefte heeft aan betaald werk blijkt verreweg het grootst te zijn.

Tabel 5.1

Ontwikkeling van de groep Limburgse werklozen en niet-participerenden (15-65 jaar)

\begin{tabular}{|c|c|c|c|c|}
\hline \multirow[t]{2}{*}{ Categorie } & \multicolumn{2}{|c|}{1994} & \multicolumn{2}{|c|}{$1999^{33}$} \\
\hline & aantal & $\%$ & aantal & $\%$ \\
\hline Werkloos: & 33.000 & 13 & 18.000 & 8 \\
\hline \multicolumn{5}{|l|}{ Beschikbaar: } \\
\hline Werk gezocht & 6.500 & 2 & 5.000 & 2 \\
\hline Geen werk gezocht & 14.000 & 5 & 13.000 & 6 \\
\hline \multicolumn{5}{|l|}{ Niet beschikbaar: } \\
\hline Niet op korte termijn beschikbaar & 13.000 & 5 & 16.000 & 7 \\
\hline Wil geen betaald werk & 172.000 & 66 & 142.500 & 62 \\
\hline VUT of pensioen & 17.500 & 7 & 20.000 & 9 \\
\hline Arbeidsongeschikt, bereid & 6.500 & 2 & 13.500 & 6 \\
\hline \multicolumn{5}{|l|}{ Totaal werklozen en } \\
\hline niet-participerenden & 262.500 & 100 & 228.000 & 100 \\
\hline
\end{tabular}

Bron: $C B S(E B B) / R O A$

Uit de tabel blijkt al dat, zoals verwacht mocht worden, de omvang van de groep werklozen en niet-participerenden de afgelopen jaren sterk is afgenomen van 262.500 in 1994 naw 228.000 personen in 1999. Daarbij is het aantal werklozen bijna gehalveerd en het aantal mensen dat beschikbaar is voor de arbeidsmarkt licht gedaald. Van degenen die nict beschikbaar zijn voor de arbeidsmarkt is de groep die niet wil werken sterk afgenomen en zijn de overige drie groepen in omvang toegenomen. Het aantal arbeidsongeschikten dal bereid is om te werken (aangeeft betaald werk te willen) is verdubbeld.

Tabel 5.2 laal zien dat het aandeel van de werklozen en de niet-participerenden dat cen opleiding op minimaal middelbaar niveau heeft genoten tussen 1994 en 1999 is toegenomen met 4 procentpunten. Het opleidingsniveau van de werklozen en de niet-participerenden is echter minder toegenomen dan dat van de totale potentiële beroepsbevolking. I Ict percentage mensen met minimaal een middelbare opleiding is bij de werklozen en de nicı-

33 De opsplitsing van de niet-participerenden die beschikbaar en niet beschikbaar zijn was voor luet jaar 2000 niet mogelijk. Daarom is gebruik gemaakı van de cijfers voor 1999. 
participerenden beduidend lager dan het gemiddelde voor de totale beroepsbevolking. Hieruit kan worden geconcludeerd dat wat betreft het opleidingsniveau de achterstand van de werklozen en de niet-participerenden ten opzichte van de werkenden tussen 1994 en 1999 is vergroot. Dit betekent dat het niet participeren op de arbeidsmarkt zich in toenemende mate concentreert bij degenen die niet beschikken over een zogenaamde 'startkwalificatie' voor de arbeidsmarkt.

Tabel 5.2

Percentage van de werklozen en de niet-participerenden met minimaal een middelbare opleiding (welke dus beschikken over een startkwalificatie), Limburg

Categorie

1994

Werkloos

Beschikbaar

Totaal werklozen en niet-participerenden

Totaal beroepsbevolking (incl. werkenden)

Bron: CBS(EBB)/ROA

Tabel 5.3 geeft een beeld van een aantal achtergrondkenmerken van de niet-participerenden in vergelijking met de werkenden. Onder de werklozen zijn met name vrouwen oververtegenwoordigd: ongeveer $60 \%$ van de werklozen is vrouw tegenover slechts $38 \%$ van de werkenden. Ook zijn de lager opgeleiden sterk oververtegenwoordigd.

Van de beschikbare niet-participerenden en degenen die niet beschikbaar zijn, is zelfs bijna driekwart van het vrouwelijk geslacht. Bijna $60 \%$ van degenen die niet beschikbaar zijn, is ouder dan 50 jaar. Dit illustreert dat het niet participeren op de arbeidsmarkt zich in belangrijke mate concentreert bij de vijftig plussers en de (gehuwde) vrouwen. Bij de andere drie groepen is ongeveer $60 \%$ van de mensen tussen de 30 en 50 jaar. Meer dan de helft van de beschikbare niet-participerenden heeft geen startkwalificatie voor de arbeidsmarkt. In de tabel is duidelijk te zien dat hoe minder beschikbaar men is voor de arbeidsmarkt, des te lager het opleidingsniveau. Het percentage niet-beschikbaren zonder een startkwalificatie is twee keer zo groot als het percentage werkenden zonder startkwalificatie. Voor de personen in de relatief grote groep van niet-beschikbaren in de leeftijdsklasse van 50 tot en met 64 jaar mag dan ook worden aangenomen dat ze, in combinatie met andere factoren als langdurige inactiviteit en geringe inspanningen voor het verwerven van een baan, slechts een kleine kans hebben op een betaalde baan. 
Tabel 5.3

Achtergrondkenmerken van de beroepsbevolking, Limburg, 1999 $9^{34}$

\begin{tabular}{|c|c|c|c|c|}
\hline \multirow[t]{3}{*}{ Kenmerk } & \multirow{3}{*}{$\begin{array}{l}\text { werkloos } \\
\qquad \%\end{array}$} & \multicolumn{2}{|c|}{ niet-participerend } & \multirow{3}{*}{$\begin{array}{r}\text { werkend } \\
\%\end{array}$} \\
\hline & & beschikbaar & niet-beschikbaar & \\
\hline & & $\%$ & $\%$ & \\
\hline \multicolumn{5}{|l|}{ Geslacht: } \\
\hline Man & 39 & 28 & 27 & 62 \\
\hline Vrouw & 61 & 72 & 73 & 38 \\
\hline \multicolumn{5}{|l|}{ Leeftijd: } \\
\hline $15-29$ jaar & - & - & 6 & 22 \\
\hline 30-49 jaar & 61 & 56 & 35 & 59 \\
\hline 50-64 jaar & - & - & 59 & 19 \\
\hline \multicolumn{5}{|l|}{ Opleiding: } \\
\hline BO-VMBO & 47 & 58 & 62 & 30 \\
\hline MBO-HAVO-VWO & 42 & 31 & 31 & 45 \\
\hline HBO-WO & - & - & 7 & 25 \\
\hline Totaal & 100 & 100 & 100 & 100 \\
\hline Aantal & 18.000 & 18.000 & 192.000 & 455.500 \\
\hline
\end{tabular}

Bron: $C B S(E B B) / R O A$

\subsection{Arbeidsverleden van de werklozen en de niet-participerenden}

Het arbeidsverleden van de werklozen en de niet-participerenden kan een indicatie geven van de mogelijkheden om opnieuw betaald werk te gaan verrichten ${ }^{35}$. Zo is het een belangrijke vraag of niet-participerenden ooil gewerkı hebben. Dit geeft immers aan of men werkervaring heeft en daardoor dus mogelijk interessanter wordt voor werkgevers. Uit tabel 5.4 blijkt dat de overgrote meerderheid van zowel degenen die beschikbaar zijn als van degenen die niet beschikbaar zijn voor de arbeidsmarkt, ooit heeft gewerkt".

34 Vanwege de ondergrenzen die door het CBS worden gehanteerd kunnen niet alle percentages worden gepresenteerd.

35 Omdat er in het Sociaal-Ecnomisch Panel (SEP), waarop de analyse in deze paragraaf grotendexls in gichaseerd, geen onderscheid naar provincies kan worden gemaakı, wordt aangenomen dat de verdeling voor Limburg hetzelfde is als voor Nederland.

36 Werk wordt hier gedefinieerd als gedurende ten minste 3 maanden meer dan 12 uur per week werken. 
Tabel 5.4

Werkervaring van de werklozen en de niet-participerenden, Limburg, 1998/1999

\begin{tabular}{lrrr} 
& werkloos & beschikbaar & niet-beschikbaar \\
& $\%$ & $\%$ & $\%$ \\
\hline Ooit werk gehad & 92 & 92 & 88 \\
Nooit werk gehad & 8 & 8 & 12 \\
Totaal & 100 & 100 & 100 \\
Aantal & 18.000 & 18.000 & 192.000
\end{tabular}

Bron: CBS (SEP, EBB)

Een interessante vraag die zich vervolgens aandient is welke reden de niet-participerenden hadden om te stoppen met werken. De voorkeuren van de niet-participerenden om eventueel weer te gaan werken worden daardoor immers kenbaar. Bovendien geeft dit een belangrijk inzicht in de factoren die van invloed zijn op de arbeidsmarktuitstroom van werkenden. Dit stelt de werkgevers in staat een meer adequaat HRM-beleid te voeren gericht op het vasthouden van personeel.

Tabel 5.5

Belangrijkste reden van uittrede van de arbeidsmarkt, Limburg, 1998/199937

\begin{tabular}{lrrr} 
& werkloos & beschikbaar & niet-beschikbaar \\
& $\%$ & $\%$ & $\%$ \\
\hline Einde contract & 38 & 16 & 11 \\
Huwelijk of zorgtaken & 35 & 45 & 40 \\
Verhuizing door baan partner & 2 & 3 & 2 \\
Arbeidsongeschiktheid of ziekte & 12 & 23 & 22 \\
Pensioen of VUT & 1 & 1 & 14 \\
Studie & 1 & 0 & 0 \\
Andere reden & 14 & 11 & 11 \\
& & 100 & 100 \\
Totaal & 100 & 16.500 & 169.000 \\
Aantal & 16.500 & &
\end{tabular}

Bron: CBS (SEP, EBB)

Uit tabel 5.5 blijkt dat de geboorte of het verzorgen van kinderen veruit de belangrijkste reden is om te stoppen met werken. Opvallend is dat dit in grotere mate geldt voor de beschikbare mensen dan voor de niet-beschikbare. Dit wijst erop dat vrouwen die stoppen met werken vanwege de geboorte of het verzorgen van kinderen vaker dan andere nietparticiperenden bereid zijn tot herintrede op de arbeidsmarkt. Hieruit blijkt het grote

37 Het betreft hier slechts de mensen die ooit een werkkring hebben gehad. 
belang van voldoende faciliteiten voor kinderopvang om de arbeidsmarktparticipatie van vrouwen te vergroten. Na het verzorgen van kinderen is arbeidsongeschiktheid of ziekte de belangrijkste reden om te stoppen met werken. Zoals verwacht is het einde van het contract of tijdelijke aanstelling met name voor werklozen een belangrijke oorzaak voor het stoppen met werken al is dit ook bij 1 op de 6 voor de arbeidsmarkt beschikbare niet-participerenden de reden geweest om met werken te stoppen.

\subsection{Tijdsbesteding en tevredenheid van de werklozen en de niet-participerenden}

In deze paragraal zal worden ingegaan op de redenen die niet-participerenden hebben om niet toe te treden tot de arbeidsmarkt. Tabel 5.6 laat zien dat voor een derde van de nietbeschikbaren de werkzaamheden binnen het eigen huishouden de belangrijkste reden is om niet toe te treden tot de arbeidsmarkt. Daarnaast is voor ongeveer een kwart arbeidsongeschiktheid of ziekte de reden waarom men niet werkt.

Tabel 5.6

Redenen van niet-participerenden die niet beschikbaar zijn voor de arbeidsmarkt om niet toe te treden, Limburg, 1998/1999 ${ }^{3 s}$

Reden van non-participatie $\%$

Werkzaam in eigen huishouden

Arbeidsongeschiktheid of ziekte $\quad 26$

VUT of pensioen

Geen passend werk 3

Financieel niet aantrekkelijk $\quad 5$

Studie 1

$\begin{array}{lr}\text { Andere reden } & 27\end{array}$

Totaal $\quad 100$

Aantal

Bron: CBS (SEP, EBB)

Wanneer tabel 5.6 vergeleken wordt met tabel 5.5, lijkt het dat de reden om te stoppen met werken dezelfde is als de reden om niet opnieuw toe te treden tot de arbeidsmarkt. Deze conclusie geeft het belang aan van het voeren van een preventief beleid door zowel de werkgever als de overheid om arbeidsmarktuitstroom van werkenden te verminderen. De zorg voor voldoende kinderopvangplaatsen en een adequaat Arbobeleid vormen daarbij de sleutel tot het verhogen van de participatiegraad van de potentiële beroepsbevolking.

38 Omdat de voor de arbeidsmarkt beschikbare niet-participerenden aangeven werk te willen. zijn slechts degenen die niet beschikbaar zijn opgenomen in de tabel. 
In tabel 5.7 wordt ingegaan op de mate waarin niet-werkenden hun zorgtaken als een belemmering zien om weer te gaan werken. Uit deze tabel blijkt dat zorg voor kinderen of anderen met name voor werklozen en de niet-participerenden die zeggen beschikbaar te zijn voor de arbeidsmarkı een obstakel is om werk te accepteren.

\section{Tabel 5.7}

Zorgtaken als belemmering voor accepteren van voltijd dienstverband, Limburg, 1998/1999

\begin{tabular}{lrrr} 
& werkloos & beschikbaar & niet-beschikbaar \\
& $\%$ & $\%$ & $\%$ \\
\hline Geen zorgtaken & 34 & 26 & 55 \\
Zorgtaken zijn belemmering & 36 & 45 & 20 \\
Zorgtaken zijn geen belemmering & 30 & 29 & 25 \\
Totaal & 100 & 100 & 100 \\
Aantal & 18.000 & 18.000 & 192.000 \\
\hline
\end{tabular}

Bron: CBS (SEP, EBB)

Tabel 5.8 geeft eenzelfde overzicht als tabel 5.7 toegespitst op de niet-werkenden die jonger zijn dan 50 jaar. In deze tabel wordt duidelijk dat het grootste gedeelte van de niet-beschikbaren onder de 50 jaar hun zorgtaken als een belemmering ziet om te gaan werken. Hierbij is er overigens geen verschil tussen degenen die beschikbaar zijn voor de arbeidsmarkt en degenen die dat niet zijn. De werklozen zijn minder belemmerd door zorgtaken, maar ook hier geeft ongeveer $40 \%$ aan dat hun zorgtaken een belemmering vormen voor het accepteren van werk.

Tabel 5.8

Zorgtaken als belemmering van voltijd dienstverband voor mensen jonger dan 50 jaar, Limburg, 1998/1999

$\begin{array}{lrrr} & \begin{array}{r}\text { werkloos } \\ \%\end{array} & \begin{array}{r}\text { beschikbaar } \\ \%\end{array} & \begin{array}{r}\text { niet-beschikbaar } \\ \text { Geen zorgtaken }\end{array} \\ \text { Zorgtaken belemmering } & 29 & 15 & 14 \\ \text { Zorgtaken geen belemmering } & 41 & 56 & 56 \\ & 30 & 29 & 30 \\ \text { Totaal } & & & 100 \\ \text { Aantal } & 100 & 100 & 80.000\end{array}$

Bron: CBS (SEP, EBB)

Indien er door de niet-participerenden bewust gekozen word voor een leefstijl zonder betaald werk en men tevreden is met het takenpakket, zal het moeilijk worden hieruit additioneel arbeidsaanbod te rekruteren. Daarom wordt in tabel 5.9 aangegeven in hoeverre 
niet-werkenden tevreden zijn met hun huidige situatie. Uit deze tabel blijkt dat het overgrote deel (enigszins) tevreden is. Hierbij is het van belang op te merken dat de persoonlijke voorkeuren door de omstandigheden kunnen veranderen. Als kinderopvangplaatsen bijvoorbeeld meer voorhanden zijn of goedkoper worden, kunnen de voorkeuren veranderen. Geconcludeerd kan worden dat indien de omstandigheden waarbinnen niet-werkenden hun keuzes maken niet veranderen, de niet-beschikbaren slechts met grote moeite kunnen worden aangezet tot werk. Zij blijken immers meer tevreden dan de werklozen en de beschikbaren.

Tabel 5.9

Mate van tevredenheid van niet-werkenden met hun huidige situatie, Limburg, 1998/1999

\begin{tabular}{lrrr} 
& $\begin{array}{r}\text { werkloos } \\
\%\end{array}$ & $\begin{array}{r}\text { beschikbaar } \\
\%\end{array}$ & $\begin{array}{r}\text { niet-beschikbaar } \\
\end{array}$ \\
\hline (Zeer) ontevreden & 11 & 9 & 5 \\
Enigszins ontevreden & 18 & 17 & 7 \\
Enigszins tevreden & 38 & 35 & 23 \\
(Zeer) tevreden & 33 & 39 & 65 \\
Totaal & 100 & 100 & 100 \\
Aantal & 18.000 & 18.000 & 192.000 \\
\hline
\end{tabular}

Bron: CBS (SEP, EBB)

\subsection{Inzetbaarheid van de werklozen en de niet-participerenden}

\section{Toekomstperspectief werklozen en niet-participerenden}

Ten slotte kan voor het gehele onbenutte arbeidspotentieel worden nagegaan of hun kwalificaties aansluiten op de arbeidsmarkt. In tabel 5.10 wordt per opleidingsniveau het percentage werkenden, werklozen of beschikbare niet-participerenden en niel-beschikbare niet-participerenden weergegeven ${ }^{39}$. Daarnaast wordt per opleidingsniveau een indicatie gegeven van de toekomstige knelpunten in de personeelsvoorziening.

Uit de tabel blijkt dat voor de grote groep lager opgeleiden, de vraag-aanbodverhoudingen op de arbeidsmarkt geen stimulans zijn om weer aan het werk te gaan. Naast de in het algemeen lagere bereidheid van niet-werkenden met een lagere opleiding om op de arbeidsmarkt te participeren, hebben de knelpunten op de arbeidsmarkt dus ook geen aanzuigende werking op deze mensen om weer te gaan werken. Bij de hogere opleidingen (vanaf HAVO/VWO) zullen de knelpunten in de personeelsvoorziening daarentegen naar verwachting groot zijn. Hier mag dus verwacht worden dat de arbeidsmarkı een aanzui-

39 De werkenden zijn alleen opgenomen om de percentages per rij tot 100 procent te laten optellen, zij maken vanzelfsprekend geen deel uit van het onbenutte potentieel van de werklozen en de niet-participerenden. 
gende werking heeft op de niet-participerenden. Met name voor deze groep is het dus van groot belang om adequaat in te spelen op de belemmeringen die men heeft om weer aan het werk te gaan.

Tabel 5.10

Arbeidsmarktpositie potentiële beroepsbevolking naar opleidingsniveau, 1998/1999

\begin{tabular}{|c|c|c|c|c|c|}
\hline Opleidingscategorie & $\begin{array}{r}\text { werkloos of } \\
\text { beschikbaar } \\
\%\end{array}$ & $\begin{array}{r}\text { niet- } \\
\text { beschikbaar } \\
\%\end{array}$ & werkend & aantal & $\begin{array}{l}\text { toekomstige } \\
\text { knelpunten } \\
\text { personeels- } \\
\text { voorziening } \\
\text { (ITKP) }\end{array}$ \\
\hline Basisonderwijs & 8 & 53 & 39 & 98.000 & geen \\
\hline VMBO & & & & & \\
\hline (excl. VMBO theorie) & - & - & - & - & enige \\
\hline VMBO theorie & 8 & 37 & 55 & 165500 & groot \\
\hline HAVO/NWO & 7 & 22 & 71 & 27.000 & enige \\
\hline MBO & 5 & 20 & 75 & 241.000 & groot \\
\hline HBO & 9 & 17 & 74 & 91.500 & groot * \\
\hline WO & - & - & - & 26.000 & groot * \\
\hline Totaal & 6 & 28 & 66 & 689.000 & enige \\
\hline
\end{tabular}

* Landelijke arbeidsmarktprognoses

Bron: $C B S(E B B) / R O A$

In een recent onderzoek ${ }^{+1}$ naar het selectiegedrag van Limburgse werkgevers in de zorg-, IT, en metaalsector wordt aangetoond dat zij, naast iemands opleiding, ervaring een belangrijk selectiecriterium vinden. Het beschikken over enige ervaring wordt door werkgevers in de IT- en metaalsector zelfs gezien als een belangrijker criterium dan de juiste opleidingsachtergrond. De reden hiervoor is dat in de IT-sector de initiële opleiding minder belangrijk wordt gevonden, omdat er met name vaardigheden vereist zijn die door de voortdurende vernieuwingen snel verouderen en daardoor 'on the job' moeten worden geleerd. In de zorgsector zijn daarentegen de formele opleidingseisen weer zeer belangrijk. In alle onderzochte sectoren blijkt dat herintreders met relevante werkervaring een grotere kans hebben om door een werkgever te worden geselecteerd dan schoolverlaters.

Ten slotte blijkt uit het onderzoek dat werkgevers hun selectiecriteria ten tijde van een hoogconjunctuur op verschillende manieren in de drie onderzochte sectoren aanpassen. Zo geldı dat in de IT- en metaalsector, in tegenstelling tot de zorgsector, tekorten veel minder snel leiden tot openstaande vacatures, maar dat in plaats daarvan personeel wordt aangetrokken dat niet over alle vereiste kwalificaties beschikt.

to W. Smits (2001). Wie willen werkgevers? Personeclsselectie in de Zorg, de Metaalindustrie ch de IT. ROA-W2001/2, Maastricht 


\title{
Verklarende woordenlijst
}

\begin{abstract}
Arbeidsmarktinstroom van schoolverlaters
Het aanbod van nieuwe arbeidskrachten op de arbeidsmarkt, zoals deze is bepaald door de verwachte uitstroom van schoolverlaters uit het initiële dagonderwijs, de schoolverlaters van het deeltijdonderwijs, het niet-reguliere voltijdonderwijs en de beroepsgerichte volwasseneneducatie. Voor deze groep nieuwe arbeidskrachten wordt in dit rapport soms ook de alternatieve term 'nieuwkomers op de arbeidsmarkt' gebruikt.
\end{abstract}

\section{Arbeidsmarktkrapte}

Het begrip arbeidsmarktkrapte dat in deze rapportage gehanteerd wordt, is gedefinieerd als de verhouding tussen het aantal openstaande vacatures en het aantal niet-werkende werkzoekenden in bemiddelingsfase 1 per arbeidsmarktsegment. Wanneer de indicator voor de arbeidsmarktkrapte kleiner is dan één, is er sprake van een aanbodoverschot op het betreffende segment. Wanneer de indicator voor de arbeidsmarktkrapte groter is dan éen, is er sprake van een tekort aan niet-werkende werkzoekenden in het betreffende segment. Dit tekort kan twee oorzaken hebben: wanneer het aanbod getalsmatig tekortschiet is er sprake van een kwantitatief probleem. De knelpuntsindicator (zie hier beneden) zal dan groter zijn dan één. Wanneer het probleem vooral gelegen is in het feit dat het percentage niet-werkende werkzoekenden in fase 1 laag is, is dit tekort vooral een kwalitatief aansluitingsprobleem dat zich zal manifesteren in een knelpuntsindicator kleiner dan één. Aangezien werkzoekenden niet naar bedrijfssector ingedeeld kunnen worden, kan deze maatstaf niet gebruikt worden om de arbeidsmarktkrapte naar bedrijfssector te berekenen. De arbeidsmarktkrapte naar bedrijfssector is daarom gedefinieerd als het gewogen gemiddelde van de arbeidsmarktkrapte naar beroepsgroep. De wegingsfactor is daarbij gebaseerd op het aandeel van de betreffende beroepsgroep in het totale aantal openstaande vacatures in die bedrijfssector. Hoe hoger de arbeidsmarktkrapte in een bedrijfssector, hoe groter de rekruteringsproblemen.

\section{Baanopeningen}

De baanopeningen representeren de totale vraag naar nieuwkomers op de arbeidsmarki. zoals deze is bepaald door de werkgelegenheidsgroei (positieve uitbreidingsvraag) en de (netto) vervangingsvraag.

\section{Bedrijfssector}

Alle voorkomende bedrijven zijn ingedeeld in een aantal clusters. De in deze rapportage gepresenteerde informatie is - met uitzondering van de totale werkgelegenheid - verbijzonderd naar 13 bedrijfssectoren. Deze komen overeen met de door het CPB gehanteerde bedrijfssectorindeling.

\section{Bemiddelingsfase}

Het begrip bemiddelingsfase dat in deze rapportage word gehanteerd, is gebaseerd op de indeling zoals die door Arbeidsvoorziening wordt gehanteerd. Een hogere bemiddelingslase impliceert een grotere afstand tot de arbeidsmarkt:

- Fase 1: De werkzoekende voor wie arbeidsmarktinstrumenten beschikbaar zijn gerichı op directe bemiddeling of terugkeer naar de arbeidsmarkt. 
- Fase 2: De werkzoekende voor wie arbeidsmarktinstrumenten beschikbaar zijn gericht op een zodanige verbetering van de kans op werk, dat hij/zij binnen een tijdsbestek van maximaal een jaar als werkzoekende bemiddelbaar is op de arbeidsmarkt.

- Fase 3: De werkzoekende voor wie arbeidsmarktinstrumenten beschikbaar zijn gericht op een zodanige verbetering van de kans op werk, dat hij/zij binnen een tijdsbestek van meer dan een jaar als werkzoekende bemiddelbaar is op de arbeidsmarkt.

- Fase 4: De werkzoekende die tengevolge van zware persoonlijke werk-belemmeringen is aangewezen op hulp en zorg die gericht is op een zodanige verbetering van zijn/haar eigen positie dat eerst op termijn arbeidsmarktinstrumenten inzetbaar zijn gericht op de verbetering van zijn/haar kans op werk.

\section{Beroepsgroep, Beroepssector, Beroepssegment}

Alle voorkomende beroepen zijn ingedeeld in een aantal clusters. In deze rapportage en de bijbehorende Statistische Bijlage wordt afwisselend gebruik gemaakt van de indeling in 127 beroepsgroepen, 11 beroepssectoren en 43 beroepssegmenten.

\section{Bijscholing}

Er is sprake van bijscholing wanneer een scholingstraject de opleidingsachtergrond van een werkzoekende niet verandert.

\section{Bijscholingspotentieel in verhouding tot de scholingsbehoefte}

Het bijscholingspotentieel (in kwantitatieve zin) wordt gevormd door de niet-werkende werkzoekenden in fase 2 en 3 . Het bijscholingspotentieel in verhouding tot de scholingsbehoefte - het verschil tussen de som van de openstaande vacatures en de verwachte baanopeningen enerzijds en de direct inzetbare werkzoekenden (de schoolverlaters en de niet-werkende werkzoekenden in fase 1) anderzijds - geeft aan in hoeverre werkzoekenden door middel van bijscholing hun arbeidsmarktkansen kunnen vergroten. Hoe groter deze verhouding is, hoe groter de mogelijkheden voor de werkzoekenden zijn. Wanneer de bijscholingsbehoefte gering is, zijn de kansen om via bijscholing de arbeidsmarktkansen te vergroten eveneens gering.

\section{Conjunctuurgevoeligheid}

De conjunctuurgevoeligheid van de werkgelegenheid heeft betrekking op de mate waarin de werkgelegenheid voor mensen met een bepaalde opleidingsachtergrond gevoelig is voor veranderingen van de economische situatie. Deze indicator geeft daarmee de mate van werkzekerheid aan. De conjunctuurgevoeligheid wordt bepaald door de sectorale werkgelegenheidsfluctuaties in het verleden te relateren aan de mate waarin een opleidingstype momenteel in de verschillende bedrijfssectoren is vertegenwoordigd. Hierbij wordt rekening gehouden met het feit dat niet ieder opleidingstype even sterk meefluctueert met de werkgelegenheidsschommelingen van de bedrijfssector.

\section{Deeltijdarbeid}

Deeltijdarbeid betreft personen die hoogstens 32 uur maar minstens 12 uur per week werkzaam zijn. 


\section{Eigen vakrichting}

Een indicatie van de mate waarin arbeidskrachten werkzaam zijn in een functie die niet goed aansluit bij de gevolge opleidingsrichting. De mate waarin schoolverlaters buiten de eigen vakrichting werkzaam zijn wordt in dit rapport vastgesteld door de schoolverlaters zelf te laten aangeven in hoeverre voor de door hen uitgeoefende functie de eigen of een verwante opleidingsrichting vereist is.

\section{Flexibel werk}

Van flexibel werk is sprake bij uitzendkrachten, oproepkrachten, invalkrachten, contracten zonder een vast aantal arbeidsuren en indien geen vast dienstverband is overeengekomen.

\section{Frictiewerkloosheid}

Frictiewerkloosheid is de min of meer onvermijdbare werkloosheid, die het gevolg is van het feit dat het bij het veranderen van werk, of het zoeken van een eerste baan, vaak enige tijd duurt voordat men na sollicitatie wordt aangenomen.

\section{Knelpuntsindicator}

Het begrip knelpuntsindicator dat in deze rapportage wordt gehanteerd is gedefinieerd als de verhouding tussen het aantal openstaande vacatures dat niet door niet-werkende werkzoekenden in bemiddelingsfase 1 vervuld kan worden en het antal niet-werkende werkzoekenden in bemiddelingsfase 2 en 3 . Hoe hoger de knelpuntsindicator, hoe minder niet-werkende werkzoekenden met een grotere afstand tot de arbeidsmarkt er beschikbaar zijn voor de openstaande vacatures die niet door direct bemiddelbare werkzoekenden vervuld kunnen worden. Dit impliceert tevens dat een hoge knelpuntsindicator een werkzoekende in het betreffende segment de mogelijkheid biedt via bijscholing de kansen op een baan te vergroten. Wanneer het aantal niet-werkende werkzoekenden in fase 1 het aantal openstaande vacatures overtreft, is de knelpuntsindicator gelijk aan 0 . Er is dan geen sprake van een tekort aan gekwalificeerd aanbod. Het aantal banen schiet juist tekort om alle direct inzetbare werkzoekenden aan werk te helpen.

\section{Langdurig werkzoekende}

Het begrip langdurig werkzoekende dat in deze rapportage wordt gehanteerd, is gedefinieerd als een werkzoekende die langer dan een jaar ingeschreven is bij Arbeidsvoorziening. Opgemerkt dient te worden dat dit niet noodzakelijkerwijs impliceert dat de betreffende werkzoekende tijdens de periode niet gewerkı heeft.

\section{Langdurig openstaande vacature}

Het begrip langdurig openstaande vacature dat in deze rapportage wordt gehanteerd, is gedefinieerd als een vacature die langer dan drie maanden openstaat.

\section{Omscholing}

Er is sprake van omscholing wanneer het scholingstraject de opleidingsachtergrond van een werkzoekende verandert. Omscholing kan zowel niveauverhogend als richtingveranderend van aard zijn. 


\section{Onderbenutting}

Onderbenutting is een indicatie van de mate waarin arbeidskrachten werkzaam zijn op een functieniveau dat lager is dan hun opleidingsniveau. De onderbenutting van schoolverlaters wordt in dit rapport vastgesteld door de schoolverlaters zelf te laten aangeven welk opleidingsniveau vereist is voor de door hen uitgeoefende functie.

\section{Opleidingssector, Opleidingstype}

Alle voorkomende opleidingen zijn samengevoegd tot een aantal clusters. In de prognosemethodiek en in de bij dit rapport verschenen Statistische Bijlage wordt voornamelijk uitgegaan van 113 opleidingstypen. In het rapport wordt in de meeste gevallen echter een indeling naar 21 opleidingsectoren gehanteerd.

\section{Potentiële beroepsbevolking}

De potentiële beroepsbevolking omvat de werkenden, de werklozen en de niet-participerenden. Iedereen die tussen de 15 en de 64 jaar oud is en geen voltijdopleiding volgt, wordt tot de potentiële beroepsbevolking gerekend. Als men meer dan 12 uur per week werkt, wordt men tot de werkzame beroepsbevolking gerekend. Werkt men niet of minder dan 12 uur, maar wil men wel minstens 12 uur per week betaalde arbeid verrichten, dan behoort men tot de werkloze beroepsbevolking. Werkt men niet of minder dan 12 uur, en is men niet op zoek naar betaalde arbeid voor minstens 12 uur per week, dan behoort men tot de niet-participerende beroepsbevolking (de zgn. 'stille reserve').

\section{Toekomstig arbeidsmarktperspectief}

Het toekomstig arbeidsmarktperspectief geeft de verhouding tussen aanbod en vraag in de prognoseperiode voor een opleidingstype weer. Als het arbeidsmarktperspectief slecht is, betekent dit dat er in het (de) komende ja(a)r(en) veel meer aanbod van nieuwkomers is dan er baanopeningen zijn. Hierdoor zal de arbeidsmarktpositie gaan verslechteren. Deze verslechtering kan een hogere werkloosheid betekenen, maar door aanpassingsprocessen op de arbeidsmarkt kan dit ook leiden tot het moeten aanvaarden van banen op een lager niveau, een lagere beloning en meer tijdelijke contracten. Omgekeerd zal een goed perspectief tot een grotere kans op werk, maar ook tot een verbeterde positie op andere punten leiden. Het toekomstig arbeidsmarktperspectief per opleidingstype wordt bepaald door middel van de Indicator Toekomstige Arbeidsmarktsituatie (ITA), die is gedefinieerd als de verhouding tussen enerzijds de verwachte instroom van schoolverlaters en het aantal direct bemiddelbare werkzoekenden en anderzijds de verwachte baanopeningen. Naarmate de waarde van de indicator hoger is, is het perspectief slechter. Analoog geeft de Indicator Toekomstige Arbeidsmarktsituatie naar Beroep (ITAB) het arbeidsmarktperspectief naar beroepsgroep weer. Merk overigens op dat een hogere ITA of ITAB een slechtere (toekomstige) arbeidsmarktsituatie impliceert, terwijl een hogere arbeidsmarktkrapte een indicatie is voor een betere (huidige) arbeidsmarktpositie van een opleidingstype.

\section{Toekomstige knelpunten in de Personeelsvoorziening}

Als de toekomstige vraag naar werkenden met een bepaalde opleidingsachtergrond groter is dan het aanbod, kunnen knelpunten in de personeelsvoorziening verwacht worden. Vergelijkbaar met de Indicator Toekomstige Arbeidsmarktsituatie (ITA, zie hierboven) geeft de Indicator Toekomstige Knelpunten in de Personeelsvoorziening (ITKP) deze vraagaanbod-spanning aan. Het verschil met de ITA is dat bij de ITKP de uitstroom van werken- 
den als gevolg van een krimpende werkgelegenheid is meegerekend in de vraag, omdat verwacht mag worden dat bij knelpunten in de personeelsvoorziening deze (gedwongen) uitstroom kan worden afgeremd of elders werk zou kunnen vinden. Naarmate de waarde van de indicator lager is, zijn de verwachte knelpunten groter. Analoog geeft de Indicator Toekomstige Knelpunten in de personeelsvoorziening naar Beroep (ITKB) de knelpunten naar beroepsgroep weer.

\section{Toekomstige Knelpunten in de personeelsvoorziening naar Beroep}

Voor het vaststellen van de verwachte knelpunten in de personeelsvoorziening naar beroep gebruiken we de Indicator Toekomstige Knelpunten in de personeelsvoorziening naar Beroep (ITKB). Deze indicator geeft aan in welke mate werkgevers problemen ondervinden bij het aantrekken van geschikt personeel. Naarmate de waarde van de ITKB lager is, zijn er meer knelpunten te verwachten. Wanneer het aanbod kleiner is dan de vraag, dan is de ITKB kleiner dan 1,00. De knelpunten in de personeelsvoorziening worden dan als groot getypeerd. Als de waarde van de indicator zelfs kleiner is dan 0,85 dan wordt gesproken van zeer grote knelpunten. Wanneer de ITKB daarentegen tussen 1,00 en 1,05 ligi, dan wordı gesproken van enige knelpunten. Bij een hogere waarde van de ITKB is sprake van vrijwel geen knelpunten, en mocht de ITKB zelfs groter zijn dan 1,15, dan is er sprake van geen knelpunten in de personeelsvoorziening.

\section{Uitbreidingsvraag}

De uitbreidingsvraag is de vraag naar nieuwe arbeidskrachten die ontstaat door groei van de werkgelegenheid. Als er sprake is van een werkgelegenheidsdaling, is de uitbreidingsvraag negatief.

\section{Uitwijkmogelijkheden}

Dit is de mate waarin arbeidskrachten met een bepaalde opleidingsachtergrond terecht kunnen komen in andere beroepsgroepen op een aansluitend of hoger functieniveau. Deze maatstaf geeft daarmee aan in hoeverre arbeidskrachten afhankelijk zijn van de arbeidsmarktsituatie in een bepaald beroep. De uitwijkmogelijkheden worden bepaald met behulp van een spreidingsindex. Deze index geeft een indicatie van het aantal beroepsgroepen waarnaar men kan uitwijken.

\section{Vacature}

Het begrip vacature is in deze rapportage gebaseerd op de door het CBS gehanteerde definitie van een openstaande vacature, zijnde een arbeidsplaats waarvoor personecl wordt gezocht dat onmiddellijk of zo spoedig mogelijk geplaatst kan worden.

\section{Vacaturegraad}

De vacaturegraad is het aantal openstaande vacatures per 1.000 werkenden in een bedrijts, beroeps- of opleidingssector.

\section{Vervangingsuraag}

Vervangingsvraag is de vraag naar nieuwe arbeidskrachten die ontstaat doordat de arbeidsplaatsen van werkenden die met pensioen gaan, arbeidsongeschikt worden of zich (tijdelijk) terugtrekken van de arbeidsmarkt, opnieuw moeten worden opgevuld. De vervangingsvraag per beroepsgroep kan bovendien ontstaan door de berocpsmobilitcit. 
Verder kan een onderscheid worden gemaakt tussen de netto en de bruto vervangingsvraag. De netto vervangingsvraag heeft alleen betrekking op de vervangingsbehoefte voor zover deze opgevuld zou moeten worden door schoolverlaters die op de arbeidsmarkt instromen. De bruto vervangingsvraag is de totale uitstroom van werkenden die vervangen moeten worden. De bruto vervangingsvraag omvat dus ook de vervangingsvraag die zou kunnen worden opgevuld door herintreders en baanwisselaars. In het huidige rapport wordt alleen de netto vervangingsvraag gebruikt en gepresenteerd.

\section{Vraagoverschot}

Het begrip vraagoverschot wordt in dit rapport op twee manieren gebruikt. In enge zin (in hoofdstuk 1) betreft het vraagoverschot het verschil tussen het aantal baanopeningen en het verwachte aanbod van schoolverlaters. In ruime zin (omdat immers ook bij- en omscholing van niet-werkende werkzoekenden een instrument kan zijn om op knelpunten te anticiperen) is het vraagoverschot (in hoofdstuk 4) gedefinieerd als het verschil tussen de som van de openstaande vacatures en de verwachte baanopeningen enerzijds en de direct-inzetbare werkzoekenden - de schoolverlaters en de niet-werkende werkzoekenden in fase 1 - anderzijds.

\section{Werkloosheid onder schoolverlaters}

De werkloosheid onder schoolverlaters is het aantal werklozen uitgedrukt als percentage van het aantal schoolverlaters met een bepaalde opleidingsachtergrond.

\section{Werkzoekende}

Het begrip werkzoekende is in deze rapportage gedefinieerd als de bij Arbeidsvoorziening ingeschreven niet-werkende werkzoekenden, inclusief de categorie "geen beroep op dienstverlening". 
